\title{
ESTUDOS ÉTICOS EM REPRESENTAÇÃO DO CONHECIMENTO:
} uma análise da questão feminina em linguagens documentais brasileiras

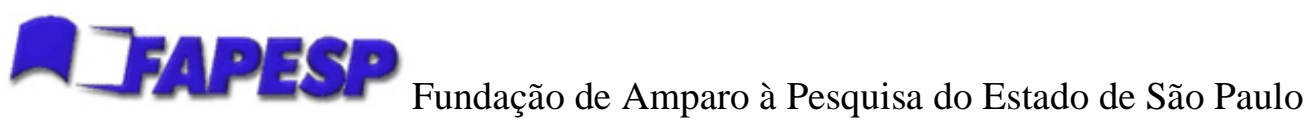


SUELLEN OLIVEIRA MILANI

\section{ESTUDOS ÉTICOS EM REPRESENTAÇÃO DO CONHECIMENTO: uma análise da questão feminina em linguagens documentais brasileiras}

Dissertação apresentada ao Programa de Pós-Graduação em Ciência da Informação da Faculdade de Filosofia e Ciências da UNESP, como requisito parcial para obtenção do título de Mestre em Ciência da Informação.

Área de Concentração: Informação, Tecnologia e Conhecimento

Linha de Pesquisa: Produção e Organização da Informação

Orientador: Prof. Dr. José Augusto Chaves Guimarães 


\section{Milani, Suellen Oliveira}

M637a Estudos éticos em representação do conhecimento: uma análise da questão feminina em linguagens documentais brasileiras / Suellen Oliveira Milani. -- Marília, 2010.

$140 \mathrm{f.} ; 30 \mathrm{~cm}$.

Dissertação (mestrado) - Faculdade de Filosofia e Ciências, Universidade Estadual Paulista, 2010.

Orientador: Prof. Dr. José Augusto Chaves Guimarães

Bibliografia: f. 120 - 129

1. Representação do conhecimento. 2. Ética informacional. 3. Ciência da Informação. I. Título.

CDD 025.4

CDU 025.4:17.022 


\section{unesp Universidade estadual PAULISTA \\ CAMPUS DE MARÍLIA \\ Faculdade de Filosofia e Ciências \\ Departamento de Ciência da Informação}

\section{CERTIFICADO DE APROVAÇÃO}

Título: ESTUDOS ÉTICOS EM REPRESENTAÇÃO DO CONHECIMENTO: uma análise da questão feminina em linguagens documentais brasileiras

Autor: Suellen Oliveira Milani

Orientador: Prof. Dr. José Augusto Chaves Guimarães

Linha de pesquisa: Produção e Organização da Informação

Apresentado como parte das exigências para a obtenção do Título de Mestre em Ciência da Informação pela Comissão Examinadora:

Prof. Dr. José Augusto Chaves Guimarães

Departamento de Ciência da Informação/ Faculdade de Filosofia e Ciências/ Universidade Estadual Paulista

Prof $^{a}$. Dr ${ }^{\mathrm{a}}$. Mariângela Spotti Lopes Fujita

Departamento de Ciência da Informação/ Faculdade de Filosofia e Ciências/ Universidade Estadual Paulista

Prof $^{a}$. Dr ${ }^{\mathrm{a}}$. Maria de Fátima Gonçalves Moreira Tálamo

Departamento de Biblioteconomia e Documentação/ Escola de Comunicação e Artes/ Universidade de São Paulo

Data da apresentação: 02 de fevereiro de 2010

Local da realização: Faculdade de Filosofia e Ciências/ Universidade Estadual Paulista/ Campus de Marília

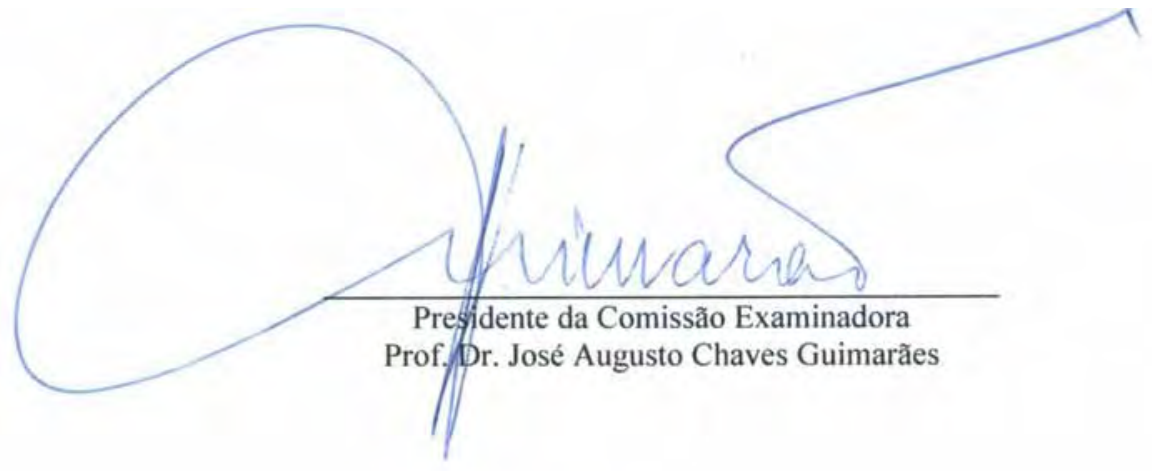


Dedico este trabalho aos meus amados pais Mario e Sueli e à minha amada irmã Samara 


\section{AGRADECIMENTOS}

À Deus, inteligência suprema.

À minha amada família, luz em minha vida.

Ao meu namorado Gilson Magalhães Pedroni, fonte de amor.

Ao Professor e orientador José Augusto Chaves Guimarães, verdadeiro mestre na arte de ensinar ciência e vida moral.

À Professora Mariângela Spotti Lopes Fujita, por acompanhar minha trajetória desde o início e por ser um modelo de cientista e mulher a ser seguido.

À Professora Maria de Fátima Gonçalves Moreira Tálamo, por acompanhar a feitura do presente trabalho em todas as suas etapas a partir de um olhar peculiar e valioso.

À Professora Lídia Maria Vianna Possas, por plantar em mim a causa social feminina na ocasião da qualificação, abrindo, assim, meus horizontes e os horizontes do presente trabalho.

To Professor Hope A. Olson, by introduce the cultural aspects in the discussions of Knowledge Organization and by encourage this research. Our sincere thanks!

À Faculdade de Filosofia e Ciências, Universidade Estadual Paulista, campus de Marília, pela estrutura e oportunidades.

Ao Programa de Pós-Graduação em Ciência da Informação, pelo incentivo a fazer a diferença.

À Fundação de Amparo à Pesquisa do Estado de São Paulo (FAPESP), por sua solidez e integridade, o que me faz sentir ainda mais orgulho em ser brasileira.

Aos professores que também contribuíram com minha formação: Ely Francina Tannuri de Oliveira, João Batista Ernesto de Moraes, Maria Leandra Bizello, Marta Lígia Pomim Valentim, Oswaldo Francisco de Almeida Júnior, Plácida Leopoldina Ventura Amorim da Costa Santos, Sidney Barbosa e Silvana Aparecida Borsetti Gregório Vidotti, minha gratidão e apreço.

Às funcionárias Margareth de Fátima Colombo Pigozzi (CEDHUM), Maria Luzinete Euclides (Biblioteca), bem como à secretaria do PPGCI, pelo apoio operacional e carinho.

Aos meus queridos amigos especiais: Fabio Assis Pinho, Franciele Marques Redigolo, Marli Vítor da Silva, Natália Bolfarini Tognoli e Thiago Bragato Barros, minha gratidão e carinho. 
We decide what to represent and what to leave unnamed (Hope Olson, 2002) 


\section{RESUMO}

A representação do conhecimento, enquanto processo, assim como os instrumentos que a permeiam e os produtos que dela decorrem, não são neutros, estando imbuídos de valores morais. Nesse cenário, emergem problemas de biasses na representação, tais como questões de gênero, categorizações dicotômicas e falta de garantia e hospitalidade cultural. No tocante à questão da mulher, amparada apenas por algumas reflexões iniciais de Berman (1993), Olson (1998, 2002), Caro Castro e San Segundo Manuel (1999), Morán Suárez e Rodríguez Bravo (2001), López-Huertas e Barité Roqueta (2002), López-Huertas, Torres e Barité (2004), López-Huertas Pérez e Torres Ramírez (2005), LópezHuertas (2006, 2008a), Guimarães (2006b, 2007) e Rodríguez Bravo (2006, 2007), há uma carência de literatura relativa à representação e ao delineamento de seu quadro epistemológico, tornando-se necessário verificar em que medida os termos relativos à questão feminina estão eventualmente inseridos sob bias nos instrumentos da área. Para tanto, verificou-se a presença dos termos: feminilidade; feminina(s); feminino(s); feminismo(s); feminista(s); materna(o); maternal; mulher(es), e os respectivos termos em inglês: female; femininity; feminism; feminist; maternal; motherly; woman(en), nas linguagens documentais brasileiras: Vocabulário Controlado Básico, Vocabulário Controlado USP, Terminologia de Assuntos da Fundação Biblioteca Nacional e Classificação Decimal de Direito. Cada termo identificado nas linguagens documentais alfabéticas teve seu descritor e não-descritores registrados, bem como notas de escopo, remissivas, termos relacionados e relações hierárquicas, enquanto as incidências relativas à linguagem documental hierárquica, foram sistematizadas de acordo com as diretrizes propostas por Olson (1998). Apresentaram-se como resultados, sinalizações de biasses, bem como possíveis auxílios para atenuá-los, enquanto pontes para discussões posteriores. Assim, reflexões devem continuar sendo realizadas para constatar e prevenir biasses na representação do conhecimento e se os profissionais da informação não forem capazes de preveni-los ou solucioná-los, a mera possibilidade da existência dos mesmos deve ser informada aos usuários, tentando, assim, tornarem-se mais responsáveis face as biasses e se colocarem explicitamente sobre as perspectivas representadas em suas unidades e sistemas de informação.

PALAVRAS-CHAVE: Representação do conhecimento; Linguagens documentais; Bias 


\begin{abstract}
Knowlede representation, as a process, as well as the tools that take part in it and the products that emanate from it are not, by any means, neutral, being soaked in moral values. In such landscape, problems of bias in representation may rise, such as gender issues, dicotomical categorizations and lack of warrant/ cultural hospitality. Concerning the women's issue, supported only by a few initial reflexions by Berman (1993), Olson (1998, 2002), Caro Castro and San Segundo Manuel (1999), Morán Suárez and Rodríguez Bravo (2001), López-Huertas and Barité Roqueta (2002), LópezHuertas, Torres and Barité (2004), López-Huertas Pérez and Torres Ramírez (2005), López-Huertas (2006, 2008a), Guimarães (2006b, 2007) and Rodríguez Bravo (2006, 2007), there is severe lack of literature related to representation and to the outlining of its epistemological frame, becoming necessary to verify how far the terms connected to the feminine issue are eventually inserted under bias in the tools of area. For such action, it was proposed to verify the presence of the following terms: female; femininity; feminism; feminist; maternal; motherly; woman(en), within the Brazilian indexing languages: Vocabulário Controlado Básico, Vocabulário Controlado USP (University of São Paulo), Terminologia de Assuntos da Fundação Biblioteca Nacional e Classificação Decimal de Direito. Each term identified in the alphabetic indexing languages had its descriptor and nondescriptors recorded, as well as the scope and remissive notes, related terms and hierarchic relations, whereas the incidences related to hierarchic indexing languages were systematized in compliance with the guidelines proposed by Olson (1998). Presented as results signs of biasses, as well as possible aid to attenuate them, as gateways to further discussions. Thus, discussions should continue being realized to detect and avoid biasses in knowledge representation and if the information professionals aren't be able to avoid or to solve them, the possibility of their existence should be informed to users, trying to become more responsible about the bias and positioning itself clearly about the perspectives represented in their information units and systems.
\end{abstract}

KEYWORDS: Subject analysis; Indexing languages; Bias 


\section{LISTA DE QUADROS}

Quadro 1 - Categorização dos termos encontrados nas quatro linguagens documentais

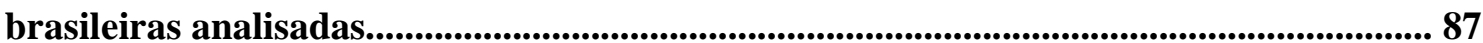

Quadro 2 - Caracterização geral das linguagens documentais analisadas........................ 130 


\section{LISTA DE TABELAS}

Tabela 1 - Incidências no VCB.

Tabela 2 - Incidências no VCUSP ........................................................................................ 85

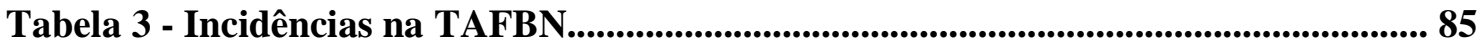

Tabela 4 - Incidências na Classificação Decimal de Direito..................................................... 86 


\section{LISTA DE ABREVIATURAS}

\begin{tabular}{|c|c|}
\hline BCI & Biblioteconomia e Ciência da Informação \\
\hline CDD & Classificação Decimal de Dewey \\
\hline CDDireito & Classificação Decimal de Direito \\
\hline CDU & Classificação Decimal Universal \\
\hline CI & Ciência da Informação \\
\hline CRG & Classification Research Group \\
\hline ISKO & International Society for Knowledge Organization \\
\hline $\mathbf{L C}$ & Library of Congress \\
\hline LCSH & $\begin{array}{l}\text { Library of Congress Subject Headings - Lista de Cabeçalhos de Assunto da } \\
\text { Library of Congress }\end{array}$ \\
\hline MARC & Machine Readable Cataloging \\
\hline $\mathbf{O C}$ & Organização do Conhecimento \\
\hline ORC & Organização e Representação do Conhecimento \\
\hline RI & Recuperação da Informação \\
\hline SORC & Sistemas de Organização e Representação do Conhecimento \\
\hline TAFBN & Terminologia de Assuntos da Fundação Biblioteca Nacional \\
\hline TE & Termo Específico \\
\hline TG & Termo Genérico ou Termo Geral \\
\hline TR & Termo Relacionado \\
\hline $\mathbf{U P}$ & Usado Para \\
\hline VCB & Vocabulário Controlado Básico \\
\hline VCUSP & Vocabulário Controlado USP \\
\hline
\end{tabular}




\section{SUMÁRIO}

1 INTRODUÇÃO...................................................................................................................... 12

2 ORGANIZAÇÃO DO CONHECIMENTO ...........................................................18

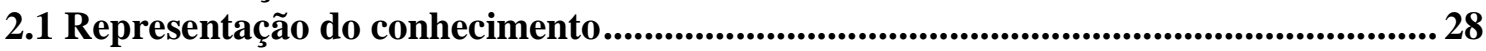

2.2 Linguagens documentais ............................................................................. 35

3 ASPECTOS ÉTICOS EM REPRESENTAÇÃO DO CONHECIMENTO .................. 41

3.1 Bias: o início de uma reflexão ............................................................................................ 48

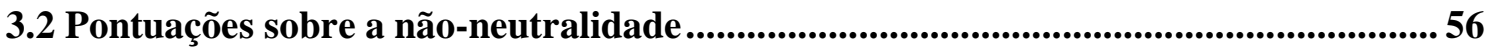

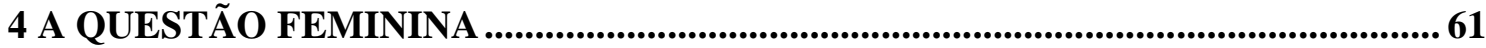

4.1 Multiculturalismo e Direitos Humanos ....................................................................... 63

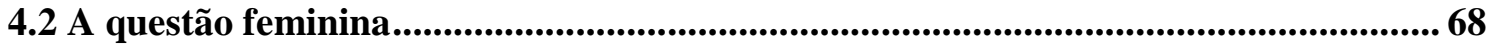

4.3 A questão feminina na representação do conhecimento .......................................... 74

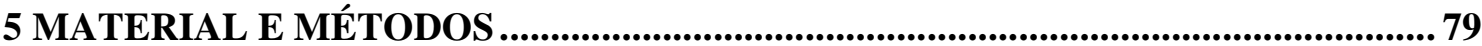

5.1 Procedimentos de pesquisa .......................................................................................... 79

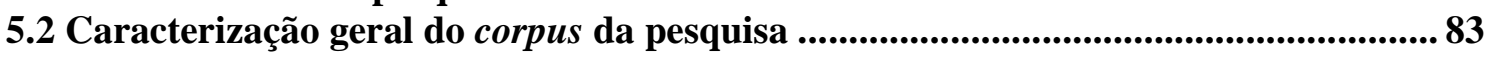

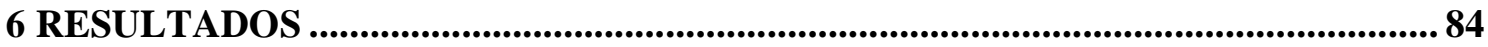

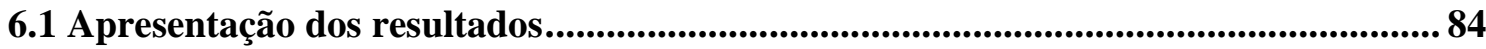

6.2 Discussão dos resultados ............................................................................................... 87

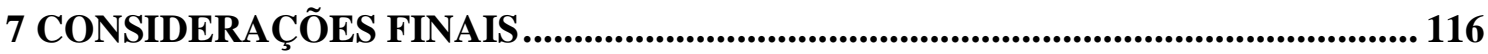

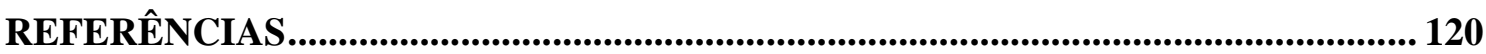

APÊNDICE A - Caracterização do corpus da pesquisa .................................................. 130 


\section{INTRODUÇÃO}

Parte-se de uma questão delicada, ou seja, falar sobre como a questão da mulher é tratada em uma área eminentemente, e, talvez, tradicionalmente, feminina como a Biblioteconomia. Adentra-se, ainda, em uma outra questão igual ou potencialmente mais delicada, ou seja, falar sobre o tecnicismo e a diminuição que o processo mais intelectual da Biblioteconomia e Ciência da Informação (BCI) (pois envolve representação e valores morais) sofre perante outras atividades, como a gestão, por exemplo.

Isso se dá a partir do que Hjørland (2008a, p. 258, tradução nossa) denomina como "[...] uma forte tendência ideológica na biblioteconomia, a desvinculação do campo dos discursos dos campos que estão sendo organizados. Essa tendência (positivismo) pode ser o mais importante bloqueio do avanço da BCI enquanto um campo acadêmico."

Essa questão é facilmente visualizada, por exemplo, quando se reflete acerca de uma política de indexação, isto é, diretrizes que orientam os parâmetros e os instrumentos que a unidade ou sistema de informação utilizará visando obter a "[...] otimização de serviços, a racionalização de processos e a consistência das operações de tratamento e organização de conteúdos informacionais [...]" (GUIMARÃES, 2001, p. 46)

$\mathrm{Na}$ elaboração de uma política de indexação que ampare as necessidades informacionais de seus usuários reais, bem como reflita a missão e objetivos de sua unidade de informação deve abranger: cobertura de assuntos; seleção e aquisição de documentosfonte; nível de exaustividade e de especificidade da indexação; escolha da linguagem de indexação; estratégia de busca; e tempo de resposta do sistema (CARNEIRO, $1985^{1}$ citado por GUIMARÃES, 2001). Orienta-se, inclusive, que a unidade de informação disponibilize aos usuários a política de indexação que utiliza para representar o conhecimento registrado e socializado que será por ele acessado. Essa iniciativa tornaria os profissionais da informação mais responsáveis pelos substitutos do conhecimento gerados.

Será realizada, a partir daqui, uma revisão, uma rediscussão, que se constitui uma postura operante no âmbito contemporâneo dos mundos das ciências e do conhecimento, afinal como defende Santos (2009), a realidade qualquer que seja é um campo de possibilidades e carece de um pensamento alternativo de alternativas.

\footnotetext{
${ }^{1}$ CARNEIRO, M. V. Diretrizes para uma política de indexação. Revista da Escola de Biblioteconomia da
} UFMG, Belo Horizonte, v. 14, n. 2, p. 221-241, 1985. 
As atuais reflexões na área de Ciência da Informação (CI) têm revelado uma mudança de paradigma, na medida em que sua ênfase já não se centra apenas em questões de recuperação, acesso e disseminação da informação, mas, muitas vezes, adentra em aspectos epistemológicos, com objetivo de sedimentar cientificamente a área. Assim, para aperfeiçoar seus referenciais teóricos e metodológicos, os pesquisadores têm se dedicado também a reflexões sobre os processos, enquanto maneiras pelas quais se realizam as operações da área, notadamente no âmbito da organização do conhecimento (OC), respaldados por normas, métodos e técnicas específicas utilizando, para isso, instrumentos, e tendo como consequências os produtos.

Esclarece-se que a presente pesquisa estudará a representação do conhecimento ${ }^{2} \mathrm{e}$ não a organização do conhecimento como um todo (análise documental: análise, síntese e representação; e classificação) ${ }^{3}$, mas foi mantida a opção terminológica de cada autor.

Tal contexto, por sua vez, encontra espaço em um cenário cada vez mais permeado pelo componente tecnológico, que não deve ser entendido como uma atividade biblioteconômica em si mesmo mas, sim, um aliado à função de recuperação e disseminação da informação. Nesse sentido, “[...] as metas dos bibliotecários não mudam, mas os meios e processos que usamos para cumprir essas metas podem, deveriam, e vão mudar" (GORMAN, 2000, p. 14, tradução nossa), tornando imprescindível à reflexão que permeia a representação do conhecimento, uma vez que a mesma, longe de ser neutra, é imbuída por valores morais e, consequentemente, por barreiras culturais.

Assim, o tema dessa pesquisa se estabelece nos aspectos éticos da representação do conhecimento, respondendo, dentre outras coisas, ao apelo registrado em um editorial da revista International Classification, em 1992, em que a pesquisadora alemã e fundadora da International Society for Knowledge Organization - ISKO, Ingetraut Dahlberg, sinalizava para a carência do tão necessário desenvolvimento teórico em questões éticas na área.

A discussão sobre ética na área da CI, como destacam Fernández-Molina e Guimarães (2002), tem sido abordada tradicionalmente em termos de prática profissional (negligência, responsabilidade), em aspectos de produção e uso da informação (liberdade intelectual, direito de acesso à informação), muitas vezes mesclada com medidas de recuperação da informação (conceitos de precisão, hospitalidade e garantia literária) ou, ainda, entendida como inerente a um conceito genérico e fluido de bom senso e bem fazer da área.

\footnotetext{
${ }^{2}$ Utiliza-se o conceito representação do conhecimento tal como utilizado pela ISKO e explicado por Rafferty (2001), que encontra como seu correspondente na escola francesa o conceito representação documental.

3 Esclarece-se que se segue a corrente teórica francesa com reflexos na Espanha e no Brasil, denominada Análise Documental.
} 
Nesse contexto, observa-se, na literatura, uma forte preocupação de natureza deontológica, voltada especificamente para os códigos de ética profissional, como bem demonstra a coletânea internacional organizada por Vaagan (2002). Por outro lado, e procurando abordar a questão sob um ponto de vista mais axiológico, autores como Froehlich (1994), Gorman (2000), Koehler e Pembertom (2000), entre outros, têm abordado o fazer profissional como um todo e de forma mais verticalizada. Especificamente no âmbito da organização e representação do conhecimento (ORC), registram-se os estudos de Berman (1993), Hudon (1997), Beghtol (2002a, 2005), Fernández-Molina e Guimarães (2002), García Gutiérrez (2002), Olson (2002, 2003), Guimarães e Fernández-Molina (2003), Van der Walt (2004), Bair (2005), Fernández-Molina et al. (2005), Guimarães et al. (2005, 2008), Pinho (2006) e Guimarães (2006b).

Nessa abordagem axiológica, distintas temáticas têm encontrado abrigo (aspectos políticos, religiosos, raciais etc.) dentre os quais se destaca a questão de gênero como um domínio do conhecimento interdisciplinar, em cujo âmbito delimita-se o problema específico da pesquisa: em que medida os termos relativos à questão feminina estão inseridos sob bias ${ }^{4}$ nos instrumentos de representação do conhecimento ${ }^{5}$ ? Essa discussão insere-se no universo da gestão das linguagens documentais ${ }^{6}$.

A representação do conhecimento é de natureza documental, desenvolve-se no contexto de uma cultura e visa a disponibilizar informações ao usuário, sendo assim deve atuar de forma a que todos, sem distinção, se sintam refletidos nessa realidade, pois caso alguma bias seja percebida, esse usuário, ou grupo de usuários, poderá se afastar do sistema de informação como um todo, por nele não se ver refletido - ou incluído.

Destaca-se que um substituto do conhecimento - um rótulo - é construído sob biasses "[...] quando deixa de incluir diversos aspectos, desprivilegia grupos e temas fora de uma norma aceita" (OLSON, 2002, p. 15, tradução nossa).

Nesse aspecto, observa-se uma carência de literatura relativa à representação da mulher e ao delineamento de seu quadro epistemológico, com exceção das reflexões de

\footnotetext{
${ }^{4}$ Optou-se por manter o termo original bias em inglês (correspondente a sesgos, em espanhol) como abrangendo os sentidos de tendência, viés, inclinação, desvio, uma vez que não se encontra, em língua portuguesa, termo que dê conta de todo o conteúdo relativo a bias.

5 Entendem-se como instrumentos de representação do conhecimento as denominadas linguagens documentais controladas (esquemas de classificação, listas de cabeçalhos de assunto e tesauros) que proporcionam uma ponte temática entre o documento e o usuário e, portanto, permitem a recuperação da informação.

6 Na presente dissertação, utiliza-se o termo linguagem documental para todas as modalidades de instrumentos de representação do conhecimento em sistemas de informação e de documentação. Nesse sentido, linguagem documental equivalem aos termos linguagens de indexação ou linguagens artificiais encontrados na literatura da área.
} 
Berman (1993), Olson (1998, 2002), Caro Castro e San Segundo Manuel (1999), Morán Suárez e Rodríguez Bravo (2001), López-Huertas e Barité Roqueta (2002), López-Huertas, Torres e Barité (2004), López-Huertas Pérez e Torres Ramírez (2005), López-Huertas (2006, 2008a), Guimarães (2006b, 2007) e Rodríguez Bravo (2006, 2007).

Desse modo, apresenta-se como proposição: a) dar continuidade aos estudos de Guimarães (2003, 2006a, 2006b), elencando, para tanto, as biasses nas linguagens documentais brasileiras, bem como apresentar discussões conceituais, de modo a colaborar com o avanço teórico interdisciplinar em temáticas relativas à representação do conhecimento e à mulher; b) analisar a presença de biasses no tocante à questão feminina em linguagens documentais ${ }^{7}$ brasileiras, comparando-os com a realidade internacional a partir da literatura.

Sendo assim, tem-se como objetivo geral: contribuir para a sedimentação teórica da área de pesquisa em Ética na representação do conhecimento por meio da análise de eventuais biasses imbuídas de preconceitos relativos à questão feminina em linguagens documentais. Como objetivos específicos, tem-se: analisar a influência do problema da discriminação nas atividades de representação do conhecimento, como já salientou Guimarães (2006b); verificar se os termos relativos à questão feminina estão inseridos sob biasses nas linguagens documentais; e comparar os possíveis termos preconceituosos em diferentes linguagens documentais nacionais.

Essa pesquisa se justificou na medida em que contribuiu diretamente para a produção de conhecimento, em questões éticas em representação do conhecimento, pois existe uma lacuna a esse respeito na literatura da área e, como foi constatado na revisão de literatura, ainda não havia sido realizado um estudo sobre a possível existência de biasses relativas à questão feminina em linguagens documentais brasileiras.

A presente pesquisa decorre de uma trajetória de investigação iniciada na Iniciação Científica (Processo FAPESP 2005/02122-0), entre 01/10/2005 e 30/09/2006, obtendo renovação para o período de 01/10/2006 a 30/09/2007, cujos resultados evidenciaram a necessidade de estudos mais verticalizados em relação as biasses que permeiam a representação do conhecimento.

Aos pareceres positivos e incentivadores dos relatórios de Iniciação Científica apresentados à FAPESP, se aliou o desejo, enquanto pesquisadora, de aprofundar os estudos

\footnotetext{
${ }^{7}$ Para efeito da presente pesquisa, utilizou-se o conceito linguagem documental, e não linguagem documentária, devido ao fato de o padrão em Língua Portuguesa da derivação dos adjetivos, a partir dos substantivos terminados em - nto (comportamento, monumento, departamento etc.), ser feita em - al (comportamental, monumental, departamental etc.) (GUIMARÃES; MORAES; NASCIMENTO, 2005, p. 135).
} 
referentes aos processos, instrumentos e produtos da representação do conhecimento em sua abordagem ética.

Ressalta-se que este estudo encontrou bases acadêmicas de realização no âmbito do Programa de Pós-Graduação da Faculdade de Filosofia e Ciências - FFC, Universidade Estadual Paulista - UNESP, Campus de Marília - SP, pois se fundamentou em estudos interdisciplinares provenientes da Ética, Filosofia e Sociologia para constatar a existência ou não de biasses nas linguagens documentais.

Desse modo, essa proposta se enquadrou na área de concentração do referido Programa de Pós-Graduação, Informação, Tecnologia e Conhecimento, mais especificamente na linha 2 Produção e Organização da Informação como demonstra sua ementa ${ }^{8}$, pois contribuirá com o desenvolvimento de referenciais teórico-metodológicos para a área, bem como para os estudos da International Society for Knowledge Organization - ISKO, principalmente no que se refere à representação temática das questões da área, que tem no Classification Scheme for Knowledge Organization Literature (DAHLBERG, 1993), seu principal instrumento.

Para tanto, a presente pesquisa qualitativa, exploratória e documental, de caráter descritivo e indutivo, verificou a presença dos termos: feminilidade; feminina(s); feminino(s); feminismo(s); feminista(s); materna(o); maternal; mulher(es); e os respectivos termos em inglês: female; femininity; feminism; feminist; maternal; motherly; woman(en), nas linguagens documentais brasileiras: Vocabulário Controlado Básico (VCB), Vocabulário Controlado USP - Universidade de São Paulo (VCUSP), Terminologia de Assuntos da Fundação Biblioteca Nacional (TAFBN) e Classificação Decimal de Direito (CDDireito).

Cada termo identificado nas linguagens documentais alfabéticas teve seu descritor, nota de escopo, relação de equivalência (Usado Para/ USE), relação associativa (Termo Relacionado) e relação hierárquica (Termo Geral/ Termo Específico) registrados, enquanto as incidências relativas à linguagem documental hierárquica foram sistematizadas de acordo com as diretrizes propostas por Olson (1998).

\footnotetext{
${ }^{8}$ Considerando a informação registrada e institucionalizada como insumo básico para a construção do conhecimento no contexto da Ciência da Informação, destaca-se o desenvolvimento de referenciais teóricos e metodológicos interdisciplinares acerca dos procedimentos envolvidos na produção e na organização da informação. Assim, a produção da informação é abordada sob os eixos da produção científica (avaliação do comportamento da ciência) e da produção documental (Diplomática contemporânea), enquanto, na organização da informação, destacam-se os processos de análise, síntese, condensação, representação e recuperação do conteúdo informacional. Ressaltam-se, como dimensões teóricas, a reflexão sobre a teoria da ciência e a organização do conhecimento, e, como dimensões aplicadas, os estudos métricos (Informetria, Cienciometria, Bibliometria e Webometria), a tipologia documental, os instrumentos e produtos de organização da informação e as questões de formação e atuação profissional na área.
} 
De modo a cumprir os objetivos da pesquisa, a seção 2 apresenta um resgate teórico acerca da representação do conhecimento a partir dos princípios postulados por Buckland (1991), partindo da OC enquanto disciplina.

A seção 3 estrutura uma discussão acerca dos aspectos éticos que permeiam a $\mathrm{OC}$, as biasses na representação do conhecimento nesse contexto, bem como algumas pontuações sobre a não-neutralidade dos processos, instrumentos e produtos de representação do conhecimento.

A seção 4, por sua vez, aborda a questão feminina e seus reflexos na representação do conhecimento a partir de biasses em um contexto multicultural e de Direitos Humanos.

A seção 5 descreve os procedimentos metodológicos utilizados e é composta por uma caracterização geral do corpus da pesquisa, enquanto a seção 6 apresenta os resultados e as discussões dos mesmos a partir da literatura selecionada.

A seção 7 finaliza essa reflexão, por meio das considerações finais.

Ressalta-se que houve a tentativa de adequar o presente texto ao Acordo Ortográfico da Língua Portuguesa (Lisboa, 1990). 


\section{ORGANIZAÇÃO DO CONHECIMENTO}

A OC, como disciplina, contribui diretamente com o campo da $\mathrm{CI}^{9}$ e, como recorda Guimarães (2000b), para se abordar teoricamente a OC, enquanto área de estudo, há, primeiramente, de se diferenciar duas concepções de conhecimento: a) enquanto processo individual; e b) enquanto algo sobre o qual existe um certo consenso social, trabalhando-se aqui com o conhecimento registrado e divulgado.

Um campo, conforme explica Saracevic (1996) é definido pelos problemas que lhe são endereçados e as metodologias que ele elege para solucioná-los. Dessa maneira, a CI é definida como um campo englobando tanto a pesquisa científica quanto a prática profissional.

A razão da existência e da evolução da CI, de acordo com Saracevic (1996), pode ser sintetizadas nos seguintes pontos:

1) É, por natureza, interdisciplinar, embora suas relações com outras disciplinas estejam mudando;

2) Está ligada à tecnologia da informação. O imperativo tecnológico causa forte impacto na CI, como ocorre também em outros campos. Em sentido amplo, o imperativo tecnológico está impondo a transformação da sociedade moderna em sociedade da informação, era da informação ou sociedade pós-industrial (ou, como acreditam alguns pensadores, pós-moderna); e

3) É, juntamente com muitas outras disciplinas, uma participante ativa e deliberada na evolução da sociedade da informação. A CI teve e tem um importante papel a desempenhar por sua forte dimensão social e humana que ultrapassa a tecnologia.

Nesse cenário, a OC, assim como muitos campos contemporâneos, busca sedimentarse e evoluir nos diversos ambientes, atuais e futuros. Segundo Esteban Navarro e García Marco (1995, p. 151, tradução nossa), “A construção da disciplina OC deve ser feita a partir das e para as Ciências da Documentação ${ }^{10}$."

A OC trata-se, então, de uma disciplina:

[...] dedicada ao estudo e desenvolvimento dos fundamentos e técnicas do planejamento, construção, gestão, uso e avaliação de sistemas de descrição,

\footnotetext{
9 É uma ciência interdisciplinar que investiga as propriedades e o comportamento da informação, as forças que governam o fluxo e o uso da informação, e as técnicas, ambas manual e mecânica, do processamento da informação para ótimo armazenamento, recuperação, e disseminação (BORKO, 1968, p. 5, tradução nossa).

${ }^{10}$ Ressalta-se que a expressão Ciência da Informação é mais utilizada na tradição norte-americana, enquanto a Europa continental se vale do termo Ciências da Documentação.
} 
catalogação, ordenação, classificação, armazenamento, comunicação e recuperação dos documentos criados pelo homem para testemunhar, conservar e transmitir seu saber e seus atos, a partir de seu conteúdo, com o fim de garantir sua conversão em informação capaz de gerar novo conhecimento. Trata-se, portanto, de uma ciência tridimensional, já que se ocupa dos princípios, métodos e instrumentos postos em ação para a gestão do conhecimento humano desde uma tripla perspectiva: sua representação, sua organização e sua comunicação documental. Não obstante, a Ciência da Representação, Organização e Comunicação do Conhecimento, denomina-se de modo mais comum e breve Organização do Conhecimento, devido a que a organização é o elemento mediador entre os outros dois atos; já que, por um lado, a representação se efetua com a finalidade de permitir uma eficaz organização, e, por outro, a comunicação exige uma correta recuperação, cujo êxito depende da qualidade da organização (ESTEBAN NAVARRO; GARCÍA MARCO, 1995, p. 149, tradução nossa).

McIlwaine e Mitchell (2008) colocam alguns pontos que norteiam essa discussão: O que é OC? Quais são os significados de documento, informação e conhecimento em OC? Quais são as questões definidas em OC? Quais campos têm interesse nas questões definidas em OC? Quais epistemologias, teorias e metodologias são relevantes no campo de OC? Quais são as questões comuns de pesquisa em OC? Quais são as questões de pesquisa em longo prazo em OC? Quais relacionamentos são específicos em OC? O que são sistemas de OC?

Elegeu-se para início de uma discussão teórica nesta seção a busca por um esclarecimento sobre o objeto e escopo da $\mathrm{OC}$ e a representação do conhecimento nesse contexto. Para tanto, será utilizada, principalmente, a abordagem apresentada pela International Society for Knowledge Organization (ISKO), uma vez que se segue sua linha de pensamento enquanto sociedade internacional que ampara as discussões formais do campo.

Em relação aos aspectos históricos, a OC pode ser sistematizada, conforme ensina Hjørland (2008b, p. 87-88, tradução e grifo nossos), em sete abordagens, as quais são comentadas a seguir.

\section{1) Abordagem tradicional da OC expressa pelos sistemas de classificação} (aproximadamente em 1876);

Ressaltam-se as contribuições de: Charles Ami Cutter (1837-1903): Regras para um Catálogo Dicionário, Expansive Classification e Tabela Numérica de Autor; Henry Evelyn Bliss (1870-1955): Bibliographic Classification e literatura produzida; Library of Congress; Melville Louis Kossuth Dewey (1851-1931): CDD, publicada em 1876 como Dewey Decimal Classification; Paul Otlet (1869-1944): Traité de Documentation (1934); e Paul Otlet e Henri de La Fontaine (1854-1943): Classificação Decimal Universal (CDU), publicada em 1905 como Manuel du répertoire bibliographique universel; dentre outros. 
Inserem-se aqui, também, as contribuições de Julius Kaiser enquanto precursor da facetagem. Straioto e Guimarães (2004) esclarecem que:

Embora sintético Kaiser apresenta em sua proposta as bases essenciais para o tratamento temático facetado, pois contempla as dimensões estática e dinâmica do conteúdo. O sistema de Kaiser [Systematic Indexing, 1911], embora idealizado para uma literatura de natureza mais técnica, aplica-se a documentos de naturezas distintas pois a essência temática (concreto) e as ações que lhe aplicam (processos) estão presentes nas mais distintas áreas do conhecimento.

\section{2) Abordagem analítico-facetada instituída por Ranganathan aproximadamente} em 1933 e mais adiante desenvolvida pelo British Classification Research Group;

Shiyali Ramamrita Ranganathan (1892-1972) estabeleceu em 1931 as Cinco leis da CI (1- Os livros são para serem usados; 2- A cada leitor o seu livro; 3- A cada livro o seu leitor; 4- Poupe o tempo do leitor; 5- A biblioteca é um organismo em crescimento); o Sistema de Classificação de Dois Pontos (Colon Classification, 1933), bem como teve sua teoria desenvolvida pelo British Classification Research Group (composto por professores, documentalistas e cientistas da informação, tais como: “[...] Vickery, Mills, Foskett, Coates, Palmer, Langridge e Austin, dentre outros" (STRAIOTO; GUIMARÃES, 2004)).

"A influência de Ranganathan nos trabalhos do Classification Research Group se fez sentir, ainda, em projetos específicos de alguns de seus membros, como o PRECIS de Derek Austin e o Thesaurofacet de Jean Aitchison" (STRAIOTO; GUIMARÃES, 2004). Ressalta-se que o PRECIS (Preserved Context Index System, 1984) consiste em um sistema précoordenado de indexação alfabética com uma parte sintática e uma semântica, enquanto o Thesaurofacet (1969) consiste na combinação do tesauro com a tabela de classificação.

\section{3) A tradição da recuperação da informação instituída na década de 1950;}

Nesse momento, a ênfase recaía na recuperação do registro em si mesmo, de acordo com estudos de Lancaster. Assim, pontos de acesso de assunto, por exemplo, “[...] eram vistos, frequentemente, como meras 'condensações semânticas' dos textos representados (implicando que o objetivo final era a representação do texto completo e nada mais)" (HJØRLAND, 2003, p. 90, tradução nossa). Desse modo, a maioria das pesquisas utilizavam metodologias quantitativas, enquanto uma pequena parte apresentava caráter qualitativo.

4) Visões orientadas ao usuário, de natureza mais cognitiva ganhando influência na década de 1970; 
5) Abordagens bibliométricas seguindo a construção do Science Citation Index de Garfield em 1963;

A respeito dessas duas abordagens, Hjørland (2003, p. 89, tradução nossa) explica que o surgimento dos estudos de usuários (Ex.: Bernal) e bibliométricos (Ex.: Bradford) “[...] podem primeiramente e mais importante, serem caracterizados por uma abordagem de conteúdo documental mais específica, um nível mais profundo de indexação, maior ênfase na tecnologia moderna e uma atitude mais científica acerca dos objetivos e problemas."

\section{6) Abordagem analítica de domínio (formulada aproximadamente em 1994);}

Considera-se, nessa abordagem, que as unidades básicas da OC são as “[...] relações semânticas das relações entre os conceitos [e que toda] relação semântica não pode ser estabelecida, primeiramente, por considerações universalistas, mas deve ser entendida como um domínio específico, como descoberto por (e construído por) disciplinas científicas" (HJØRLAND, 2003, p. 107, tradução nossa).

7) Outras abordagens (entre as sugestões mais recentes estão as abordagens da semiótica, da crítica hermenêutica, da análise do discurso e a baseada em gênero). Uma importante tendência é a ênfase nas representações do documento, tipologia e descrição do documento, linguagens de marcação, arquiteturas do documento etc.

Em cada abordagem apresentada inserem-se metodologias e teorias diversas, as quais não são abordadas nessa pesquisa, mas podem ser recuperadas em Hjørland (2002, 2003).

Especificamente na área de Biblioteconomia, Guimarães (2000b, p. 208, grifo nosso), pautando-se nos estudos de Dahlberg, verifica três fases na OC, sendo elas:

a) fase classificatória original (ou notacional), em que a tônica residia no organizar para achar (Dewey, LC etc.);

b) fase tesáurica (ou alfabética), marcada pela ruptura com os sistemas tradicionais de classificação, buscando em referenciais da Linguística soluções para a representação temática da informação;

c) nova fase classificatória (ou fase classificatória revisitada, como define Dahlberg), em que reconhece a complementaridade da organização lógica de conceitos e de sua representação linguística (Bliss, CRG, Aitchison, ISKO). Ressaltase que foi nesse momento que Dahlberg fundamentou a Teoria do Conceito.

Em relação ao conceito e objeto de estudo, Hjørland (2008b) atesta que o termo OC é originado no campo da Biblioteconomia e foi estabelecido por volta de 1900 por autores como Charles Ami Cutter e Ernest Cushington Richardson e estabilizado por W. C. Berwick Sayers e Henry Bliss. O livro The organization of knowledge and the system of the sciences, 
de Henry Bliss (1929), “[...] representa uma das principais contribuições intelectuais no campo" (HJØRLAND, 2008b, p. 97, tradução nossa).

Ao sintetizar as ideias dos referidos autores, Hjørland (2008b, p. 97, tradução nossa) destaca que as classificações bibliográficas “[...] são baseadas na organização do conhecimento, em como ela aparece na ciência e no saber", refletindo a natureza da realidade.

Bliss acreditava que o conhecimento é, relativamente, “[...] segurança e verdade, que é a razão pela qual um tipo de consenso poderia ser estabelecido. Por causa disso, Bliss e sua escolha contemporânea do termo 'organização do conhecimento', 'conhecimento' entendido na tradição Platônica como 'autêntico, crença verdadeira'” (HJØRLAND, 2008b, p. 97, tradução nossa).

Duas visões de conhecimento podem ser contrastadas na OC, conforme ensina Hjørland (2008b), sendo elas: 1) Visão positivista: Conhecimento e OC enquanto uma transcrição nua ou duplicação de algum arranjo acabado e feito pré-existente na natureza; 2) Visão pragmática: Conhecimento e OC como alguma coisa construída para lidar com algumas necessidades e interesses humanos.

$\mathrm{O}$ autor acredita que deveria se conversar sobre knowledge claims (declarações de conhecimento) e organization of knowledge claims (organização de declarações de conhecimento). A implicação é que "[...] cada declaração de conhecimento é amparada por e ligada a argumentos, teorias e visões de mundo. Se isso for reconhecido pelas pessoas que executam a OC, então a atividade não está baseada no "positivismo"” (HJØRLAND, 2008b, p. 98, tradução nossa).

Nessa mesma linha de pensamento, Guimarães (2000b, p. 208) destaca que se verificam dois tipos de preocupações advindas da área da Documentação, ou seja, "Em um âmbito teórico, tem-se a necessidade de sistematização e consolidação de um conhecimento (conjunto de saberes) verificável em uma dada sociedade em um dado momento histórico, com o objetivo de transmissão", destacando os trabalhos dos filósofos ligados à Teoria do Conhecimento, tais como Aristóteles, Platão, Porfírio, Bacon e Harris, e educadores, tal como Comênio. Por outro lado, tem-se, em um âmbito mais pragmático, “[...] a necessidade de resgate do conhecimento registrado em documentos, visando ao seu acesso, com um objetivo de recuperação" (GUIMARÃES, 2000b, p. 208), destacando os trabalhos de documentalistas, tais como Calímaco, Otlet e La Fontaine.

Desse modo, a área de OC, como destaca Barité (2001, p. 41, tradução nossa), “[...] tem por objeto principal o conhecimento socializado [...]" e registrado, desempenhando, assim, uma função essencial entre a informação e o usuário. Enquanto disciplina abarca o 
“[...] desenvolvimento de técnicas para a construção, a gestão, o uso e a evolução de classificações científicas, taxonomias, nomenclaturas e linguagens documentais. Por outro lado, aporta metodologias de uso e recuperação por meio de linguagem natural" (BARITÉ, 2001, p. 41, tradução nossa).

Trata-se, desse modo, de um universo que,

[...] procura, então, apresentar um modelo conceitual adequado às diversas práticas e atividades sociais vinculadas com o acesso do conhecimento, e pretende operar como instrumento de tratamento da informação, e da gestão de uso da informação, abarcador e integrador dos fenômenos e das aplicações vinculados à estruturação, à disposição, ao acesso e à difusão do conhecimento socializado (BARITÉ, 2001, p. 39-40, tradução nossa).

Nesse sentido, a OC, conforme ensina Guimarães (2000b, p. 210), realiza um circuito, sendo "[...] o estudo das possibilidades de organização de um conhecimento registrado sob a perspectiva de geração de novo conhecimento que, uma vez registrado, transforma-se em informação (conhecimento em ação, na concepção de Dahlberg, 1993, p. 214) para gerar novo conhecimento."

Esse universo é amparado pela ISKO, que é a primeira sociedade acadêmica internacional dedicada à teoria e à prática da OC. McIlwaine e Mitchell (2008) sinalizam que apesar de a maioria dos membros da ISKO advirem da área da BCI, a OC não se limita a esse campo e destacam as contribuições interdisciplinares e a confusão sobre o significado de organização do conhecimento e sua relação com outros campos como gestão do conhecimento, por exemplo.

De acordo com um anúncio publicado na revista International Classification $^{11}$, no dia 22 de julho de 1989, um grupo de alemães e não-alemães da Sociedade Alemã de Classificação reuniu-se no restaurante Intercity, em Frankfurt, fundou a ISKO e estabeleceu as propostas da sociedade, elegendo como presidente a $\mathrm{Dr}^{\mathrm{a}}$. Ingetraut Dahlberg.

A sociedade foi criada, segundo o anúncio, com o objetivo de unir nacional e internacionalmente membros pessoais e institucionais, interessados em, segundo a carta patente Art. 4.1 “[...] pesquisa, desenvolvimento e aplicação de todos os métodos de organização do conhecimento em campos gerais ou particulares, integrando, especialmente, a aproximação das pesquisas em classificação e inteligência artificial.”

\footnotetext{
${ }^{11}$ ANNOUNCEMENT. The foundation of the International Society for Knowledge Organization. Frankfurt, 22 july 1989. International Classification, Frankfurt, v. 16, n. 2, p. 71-72, 1989.
} 
A ISKO tem atuado, assim como o proposto, como um fórum internacional em um âmbito amplo e interdisciplinar, contribuindo para o avanço da produção literária em OC em todas as suas formas, inclusive bases de dados, bibliotecas, dicionários e Internet.

Atualmente, A ISKO tem como presidente (2006-2010) a Dra . María José LópezHuertas, professora da Faculdade de Biblioteconomia e Documentação, Universidade de Granada, Granada, Espanha, e desempenha como atividades mais importantes: conferências internacionais a cada dois anos; conferências nacionais e regionais em tópicos especiais; publicações de caráter científico na Knowledge Organization; um boletim informativo incorporado a Knowledge Organization intitulado ISKO News; e as séries Advances in Knowledge Organization - AKO e Knowledge Organization in Subject Areas - KOSA.

A revista Knowledge Organization ${ }^{12}$ (KNOWLEDGE..., 2008) reflete os interesses da própria sociedade, atua como fórum para todos aqueles interessados na OC em um domínio de escala universal ou específica, utilizando abordagens de conceito analítica ou sintética, assim como metodologias quantitativas e qualitativas. A revista também veicula compilações intelectual e automática e uso de sistemas de classificação e tesauro em todos os campos do conhecimento, com atenção especial aos problemas de terminologia.

A sociedade coopera com organizações nacionais e internacionais, como por exemplo: a UNESCO; a European Comission; International Organization for Standardization - ISO; International Federation of Library Associations and Institutions - IFLA, principalmente com a Seção de Classificação e Indexação; a American Society for Information Science and Technology - ASIST, especialmente com o SIG/ CR (o Grupo com Interesse Especial em Pesquisa em Classificação); Networked Knowledge Organization Systems/ Services - NKOS; e The International Information Centre for Terminology - Infoterm.

Em suma, a ISKO

[...] está concebida como um círculo internacional de pesquisadores, especialmente aqueles inerentes à Ciência da Informação, que trabalham com os problemas relacionados à organização conceitual do conhecimento, trazendo influências das teorias desenvolvidas por Ranganathan e pelo Classification Research Group (PINHO, 2006, p. 15).

12 A Knowledge Organization, distribuída trimestralmente pela ERGON-Verlag (ISSN: 0943-7444), Würzburg, Alemanha, apresenta fator de impacto ISI 0,533. Criada em 1973 por um grupo de acadêmicos que contava com um grupo editorial que representava as regiões do mundo e também, os ramos especiais da classificação e as áreas de assunto envolvidas, a revista era intitulada International Classification. Em 1989, tornou-se órgão oficial da ISKO e, em 1993, no volume 20, seu nome mudou para Knowledge Organization. O conteúdo da revista é indexado e resumido nas bases de dados: Information Science Abstracts; INSPEC; Library and Information Science Abstracts - LISA; Library Literature; PASCAL; Referativnyi Zhurnal Informatika; e Sociological Abstracts. O editor-chefe da Knowledge Organization é o Dr. Richard P. Smiraglia, professor da Escola de Biblioteconomia e Ciência da Informação da Long Island University, New York, Estados Unidos. 
De acordo com Dahlberg (2008), a assembleia fundadora da ISKO decidiu não utilizar mais em seu nome classificação por causa das sociedades de classificação numericamente orientadas. "Uma vez que o termo 'ordem', como foi utilizado no título da minha dissertação poderia implicar no inglês outra conotação, pensamos em utilizar 'organization of knowledge' como Bliss havia feito em seus dois livros" (DAHLBERG, 2008, p. 84, tradução nossa). Posteriormente, decidiu-se denominar knowledge organization, enquanto um termo mais sucinto e que traduziria fielmente o termo em alemão. Dahlberg (2008) explica que o termo foi aceito e "Todavia, nosso campo de empreendimento é a classificação conceitual, bem como, é claro, a teoria do conceito, indexação do conceito, representação/ terminologia do conceito" (DAHLBERG, 2008, p. 84, tradução nossa).

A ampla aceitação da OC, embora confundida por algumas pessoas com gestão do conhecimento, entre outras áreas, "[...] implica que ela tem que se mudar do presente lugar sob 'classificação e indexação' nos estabelecimentos da BCI, onde ela é até mesmo negligenciada por causa das novas possibilidades da Internet" (DAHLBERG, 2008, p. 85, tradução nossa).

A autora ressalta que para o desenvolvimento conceitual do conhecimento da área, há a necessidade do reconhecimento das contribuições interdisciplinares, mais especificamente dos cientistas e especialistas de cada campo de assunto, dos terminologistas e dos especialistas treinados em OC.

Dahlberg (2008, p. 85, tradução nossa), alerta que:

Somente se essa nova ciência puder ser considerada como um campo de empreendimento científico, ela receberá a reputação que merece. Por isso, institutos de organização do conhecimento devem ser estabelecidos onde se trabalhe a definição e sistematização (estabelecendo a posição correta de cada conceito no sistema) em um dado campo do conhecimento [...]

E Pinho (2006, p. 20) completa que “[...] é difícil esboçar o progresso teórico e científico da área, visto que, nesse campo, a maior parte dos pesquisadores segue linhas de pensamento diferentes, além de estar fragmentado, ocasionando a falta de uma melhor fundamentação teórica sobre a própria área [...]"

Em relação aos fundamentos teóricos que abarcam a OC, pontuam-se dois sentidos: estrito e amplo ${ }^{13}$.

\footnotetext{
${ }^{13}$ Brascher e Café (2008) não concordam com Hjørland, e, consequentemente, com a presente pesquisa, e fazem uma distinção entre OC (construção de modelos de mundo que se constituem em abstrações da realidade, por meio de estruturas conceituais - representação do conhecimento) e Organização da Informação (arranjos
} 
No sentido estrito, de acordo com Hjørland (2008b, p. 86, tradução nossa), a OC aborda

[...] atividades tais como descrição de documentos, indexação e classificação executadas em bibliotecas, bases de dados bibliográficas, arquivos e outros tipos de "instituições de memória" por bibliotecários, arquivistas, especialistas em informação, especialistas de assunto, bem como por algoritmos de computador e leigos.

$\mathrm{O}$ autor destaca a BCI como a disciplina central dessa abordagem estrita, influenciadas por outras como a ciência da computação, por exemplo.

Em um sentido mais amplo, conforme explica Hjørland (2008b, p. 86, tradução nossa), a OC refere-se à “[...] divisão social do trabalho mental, p. ex. a organização de universidades e de outras instituições para pesquisa e educação superior, a estrutura de disciplinas e profissões, a organização social da mídia, a produção e disseminação do 'conhecimento' etc."

Em síntese, no sentido amplo a OC aborda a organização social do conhecimento (p. ex.: organização acadêmica) e no sentido estrito a OC abarca a organização documental (p. ex.: o processo de indexação).

Assim, “Não existe um 'universo do conhecimento' fechado que possa ser estudado pela OC isolado de todos os estudos da realidade de outras ciências" (HJØRLAND, 2008b, p. 87, tradução nossa).

A descrição do campo de OC perpassa outras perspectivas teóricas, desse modo, Hjørland (2008b, p. 87, tradução nossa) ressalta que “[...] temos que examinar e interpretar diferentes rótulos utilizados por abordagens muito honesta e cuidadosamente. Diferentemente, ficaremos em um campo muito desordenado."

Em relação à tecnologia da informação, o progresso da OC é influenciado por cinco estágios, sendo eles: indexação manual e classificação em bibliotecas e serviço de referência; documentação e comunicação científica; armazenamento e recuperação da informação por computadores; recuperação baseada em citação e Organização do Conhecimento; texto completo, hipertexto e internet (HJØRLAND, 2003).

A essa discussão estão aliadas as dez premissas básicas que embasam teoricamente a OC, propostas por Barité (2001, p. 42-53, tradução nossa), a saber:

sistemáticos, por meio das descrições física e de conteúdo - representação da informação). Tem-se, dessa maneira, "[...] dois tipos distintos de processos de organização, um que se aplica às ocorrências individuais de objetos informacionais - o processo de organização da informação, e outro que se aplica a unidades do pensamento (conceitos) - o processo de organização do conhecimento" (BRASCHER; CAFÉ, 2008). 
1) O conhecimento é um produto social, uma necessidade social e um dínamo social;

2) O conhecimento se realiza a partir da informação e, ao se socializar, se transforma em informação;

3) A estrutura e a comunicação do conhecimento formam um sistema aberto;

4) $\mathrm{O}$ conhecimento deve ser organizado para o seu melhor aproveitamento individual e social;

5) Existem "n" formas possíveis de organizar o conhecimento;

6) Toda organização do conhecimento é artificial, provisional e determinista;

7) O conhecimento se registra sempre em documentos, como conjunto organizado de dados disponíveis e admite usos indiscriminados;

8) O conhecimento se expressa por meio de conceitos e é organizado por meio de sistemas de conceitos;

9) Os sistemas de conceitos se organizam para fins científicos funcionais ou de documentação;

10) As leis que regem a organização de sistemas de conceitos são uniformes e previsíveis e se aplicam por igual a qualquer área disciplinar.

Em suma, "As tradições, ideologias e paradigmas na OC devem ser vistos como a combinação de conceitos entre a organização intelectual e social ${ }^{14}$. Elas são organizações cognitivas baseadas em influências sociais” (HJØRLAND, 2003, p. 94, tradução nossa).

Hjørland (2003) ensina que paradigmas ${ }^{15}$ são compostos por: 1) Ideais e crenças sobre ciência (objetivos epistêmicos, métodos e critérios na produção e avaliação de resultados científicos dentro da disciplina); 2) Hipóteses de visão de mundo, suposições ontológicas básicas; e 3) Ideais significativos para a sociedade e cultura, para uso prático e para a sabedoria.

\footnotetext{
${ }^{14}$ Hjørland (2003) sinaliza a existência da OC Cognitiva - estrita - (OC em conceitos, sistemas conceituais e teorias) e a OC Social - ampla - (OC em profissões, tendências e disciplinas).

${ }^{15}$ Dentro de uma disciplina formal, diversas teorias maiores podem coabitar, mas há um paradigma apenas quando uma teoria experimentada domina sozinha todas as teorias e é aceita por toda a comunidade científica. Quando Pasteur descobriu o micróbio, a teoria da geração espontânea ruiu: contágio se tornou o novo paradigma. Nas ciências sociais, no entanto, vemos, quando muito, um confronto entre diversas teorias não testadas. Na maior parte do tempo não há um confronto ainda, mas cuidadosa anulação mútua, desprezo de todos os lados. Isso é relativamente fácil devido à extensão das disciplinas científicas, e suas divisões nas escolas; isso é verdadeiro para todos os países, grandes ou pequenos (DOGAN, 2001, p. 11024 citado por HJØRLAND, 2003, p. 100, tradução nossa).

DOGAN, M. Paradigms in the social sciences. In: SMELTSER, N. J.; BALTES, P. B. (Ed.). International Encyclopedia of the Social \& Behavioral Sciences. Amsterdam: Elsevier, 2001. v. 16. p. 11023-11027.
} 
As bases da OC na CI “[...] são fortemente ligados à discussão das diferentes teorias da epistemologia" (HJØRLAND, 2003, p. 107, tradução nossa), mas atua, ainda, como uma teoria maior.

Destaca-se, nesse sentido, uma variedade de paradigmas percebida no decorrer da história da CI e, consequentemente, da OC. Assim, tem-se, segundo Guimarães (2000b, p. 210):

a) no documento, o suporte (que, como tal, deve ser objeto de estudo, mormente em questões relativas a sua proveniência, organicidade e autenticidade) pois, como afirma Popper, ao mundo físico e cultural se agrega o mundo documental;

b) na informação [aqui entendida como conhecimento registrado e socializado composto por informações em potencial], o conteúdo veiculado pelo documento, sua fonte primordial de busca;

c) no conhecimento, o que se almeja com a apropriação da informação.

Considerando que a OC é um marco teórico-conceitual que lida com o conhecimento registrado e socializado, amparando, dessa maneira, a atuação do profissional da informação, destaca-se a representação do conhecimento como sendo sua principal contribuição para a área da CI, por meio das representações (físicas, digitais e virtuais) descritiva e temática do conhecimento.

Nas palavras de Barité (2001, p. 38, tradução nossa), a OC, enquanto um fazer do profissional da informação, busca apresentar “[...] subsídios teóricos (e realimentar-se) com tudo aquilo que é relativo ao tratamento da informação, particularmente com o tratamento temático da informação, e de um modo menos específico - mas não menos importante - com a gestão do uso social da informação."

\subsection{Representação do conhecimento}

Em relação à questão da representação do conhecimento, enquanto uma importante faceta da OC que, como simplifica Buckland (1991), não é mais do que um determinado filme é de um determinado evento, destaca-se que tem como objetivo a recuperação relevante de informação pelo usuário a partir de sistemas de organização e representação do conhecimento (SORC). 
Sobre o feedback com relevância, resultado e valor muito prezados pela OC a partir da representação do conhecimento, Hjørland (2008b, p. 92, tradução nossa) pontua que:

1. [...] é baseado em certas premissas sobre o conhecimento do usuário que é muito inexplorado e pode comparecer para ser altamente irreal: Se os usuários não têm o conhecimento necessário para classificar um domínio, não podem distinguir documentos relevantes e não-relevantes e são, dessa forma, incapazes de fornecer feedback úteis.

2. [...] representa relações semânticas não específicas e não claras entre documentos considerados relevantes. Por que preferir um tipo de sistema que implique relações não específicas ao invés de relações específicas e controladas pelo usuário?

Os resultados do feedback com relevância têm considerado principalmente os resultados estatísticos e têm se esquecido "[...] de investigar como diferentes tipos de representação e algoritmos podem servir a diferentes visões e interesses" (HJØRLAND, 2008b, p. 87, tradução nossa). Em outras palavras, a relevância, assim como muitas outras variáveis que envolvem a recuperação da informação, deixou de ser apenas uma medida estatística para assumir o papel de valor da área no tocante ao usuário e suas necessidades de informação, conforme ressaltam Guimarães et al. (2008).

Hjørland (2008b) destaca a confusão que ocorre na área entre os conceitos usuário e subjetividade (visões coletivas compartilhadas por muitos usuários). Há a necessidade da valorização da criação de diferentes representações do mesmo documento para amparar diversos usuários, bem como o reconhecimento da não-objetividade e não-neutralidade da representação do conhecimento, e, principalmente, que uma representação do conhecimento não ampara a todos.

Quando se adentra em discussões conceituais é interessante destacar a divisão que Buckland (1991) ${ }^{16}$ apresenta desse processo: informação-como-processo (alguém é informado de algo e o que ele sabe se modifica; ato de informar); informação-como-conhecimento (o conhecimento comunicado diz respeito a algum fato particular, assunto ou evento; fruto do processo de informar), ambas envolvendo a Ciência Cognitiva; e informação-como-coisa (objetos, como dados ou documentos, considerados informativos).

\footnotetext{
${ }^{16}$ Partilhando da visão do autor, Smit e Barreto (2002, p. 21) definem informação como sendo “[...] estruturas simbolicamente significantes, codificadas de forma socialmente decodificável e registradas (para garantir permanência no tempo e portabilidade no espaço) e que apresentam a competência de gerar conhecimento para o indivíduo e para o seu meio. Estas estruturas significantes são estocadas em função de um uso futuro, causando a institucionalização da informação."
} 
Qualquer representação “[...] está necessariamente na forma tangível (indício, sinal, dado, texto, filme etc.) e então representações do conhecimento (e de eventos) são necessariamente "informação-como-coisa"” (BUCKLAND, 1991, p. 352, tradução nossa).

Esclarece-se, assim, que “[...] qualquer expressão, descrição ou representação pode ser informação-como-coisa” (BUCKLAND, 1991, p. 351, tradução nossa), que é o objeto das áreas aplicadas da CI, que podem ser denominadas no todo como Documentação: Biblioteconomia, Arquivologia e Museologia.

Smit (1994) diferencia a representação (ou descrição) nessas três áreas aplicadas, chamadas por ela de "3 Marias" (devido aos laços comuns que as perpassam), da seguinte maneia: Na Biblioteconomia a descrição é realizada apenas uma vez, havendo apenas algumas exceções, como no caso da baixa do acervo. Já o arquivista "[...] trata os documentos de acordo com sua origem, imaginando cada documento inserido numa ordem maior de documentos que representam funções semelhantes, priorizando, consequentemente, a questão da tipologia documental [...]" (SMIT, 1994, p. 13). Os museólogos, por sua vez, “[...] consideram que a descrição que fazem dos objetos que têm sob sua guarda pode ser constantemente apurada, em decorrência de novas pesquisas e novas informações [...]" (SMIT, 1994, p. 13). Deve-se, dessa maneira, tomar muito cuidado com os intercâmbios dos profissionais da informação entre as "3 Marias", dada as especificidades do processo de representação em cada área.

Nos SORC, potencializados pelas tecnologias de informação e comunicação, muita da informação “[...] tem sido processada por ser codificada, interpretada, resumida, ou, de outro modo, transformada" (BUCKLAND, 1991, p. 358, tradução nossa) e muitas vezes alguma coisa do original é perdida, mesmo que seja somente incompleteza, finaliza o autor.

Em uma vertente mais aplicada, "[...] não pode haver algo como um sistema especialista 'baseado em conhecimento' [knowledge-based] ou um sistema 'de acesso ao conhecimento' [knowledge access], somente sistemas baseados em representações físicas do conhecimento" (BUCKLAND, 1991, p. 352, tradução nossa), conforme exposto na página 22.

Parte-se, então, da divisão que o autor coloca: aspectos da informação intangíveis: informação-como-conhecimento; conhecimento (Entidade 2); informação-como-processo; tornar-se informado (Processo 1); e tangíveis: informação-como-coisa; dado, documento (Entidade 3); e processamento da informação; processamento do dado (Processo 4).

A CI lida com coisas que tenham o mínimo de materialidade e institucionalização (monumentalização e estar ao lado de seus congêneres, respectivamente), quando há um 
referente, um registro, uma evidência ${ }^{17}$, ou seja, uma representação primária que possa se perpetuar no tempo e no espaço. O conhecimento tem de ser materializado para ser socializado.

Nesse contexto, Guimarães (2008) comenta o reflexo das ideias de Otlet nos trabalhos do próprio Michael Buckland e de Suzanne Briet (Qu'est-ce que la documentation, 1951) e destaca que Briet “[...] preocupou-se com a delimitação conceitual de documento enquanto evidência concreta ou simbólica, registrada e conservada, visando a representar, reconstruir ou provar um fenômeno físico ou intelectual" (GUIMARÃES, 2008, p. 35). O documento, de acordo com a autora, afirma Guimarães (2008), pressupõe: delimitação espacial e temporal; caráter permanente na medida em que conserva um conteúdo e inteligibilidade ${ }^{18}$.

No tocante aos objetos, a abordagem dos documentalistas era de usar documento "[...] como um termo genérico para denotar qualquer fonte de informação física em vez de limitá-lo a objetos de texto em um meio físico específico como um papel, papiro, vellum, ou microfilme" (BUCKLAND, 1991, p. 354, tradução nossa), assim, segundo o autor, objetos se tornam documentos assim que são processados para propósitos informacionais. $\mathrm{O}$ autor divide os objetos em: artefatos intencionais a constituir discurso (tais como livros), artefatos que não foram intencionais (tais como navios), e objetos que não são artefatos (tais como animais).

Entende-se por discurso uma composição de sentidos advinda de um sujeito ou uma comunidade. $\mathrm{O}$ texto (em todas as suas manifestações e formas) atua como a materialização de um discurso e ao analisá-lo a partir da metodologia da análise de discurso, assim como ocorre nos processos de representação do conhecimento, o analista "[...] através de um dispositivo analítico, [...] explicita (torna visíveis) os gestos de interpretação que textualizam a discursividade e ele interpreta os resultados dessa análise, no interior de um dispositivo teórico" (ORLANDI, 2008, p. 78).

Buckland (1991) apresenta, assim, três diferentes modos de evidência de eventos, sendo elas: 1) objetos, que podem ser colecionados e representados, podem existir como evidência associada a eventos, p. ex.: manchas de sangue no carpete ou uma pegada na areia; 2) Representações do evento em si mesmo, p. ex.: fotos, reportagens de jornais, biografias, tais documentos podem ser armazenados e recuperados; e 3) Criação ou recriação de

\footnotetext{
${ }^{17}$ Evidência é um termo apropriado porque denota alguma coisa relacionada ao entendimento, alguma coisa que, se encontrada e entendida corretamente, poderia mudar o conhecimento, as crenças de alguém, no que diz respeito a uma questão (BUCKLAND, 1991, p. 353, tradução nossa). Isso ocorre com a evidência no aprendizado, por exemplo, enquanto base para o entendimento.

18 "Com isso, a autora distingue fenômenos, objetos e criaturas (como uma estrela no céu, uma pedra no rio ou um animal na selva) de documentos propriamente ditos (tais como uma foto da estrela, a pedra no museu e o animal no jardim zoológico)" (GUIMARÃES, 2008, p. 35).
} 
eventos, p. ex.: nas ciências experimentais isso é considerado como sendo de grande importância para um experimento - um evento - ser desenhado e descrito de modo que esse possa ser replicado subsequentemente por outros. Desde que um evento não possa ser armazenado e desde que as explicações dos resultados sejam não mais do que rumores de evidência, a possibilidade de re-executar o experimento bem como a validade da evidência, da informação, poder ser verificada, é altamente desejável.

Emergem, então, duas questões: o que chamar de "outras coisas informativas" (tais como fósseis, pegadas e gritos de terror, por exemplo) e quanto é necessário processar e agregar ao dado para ele ser denominado informação? (BUCKLAND, 1991)

Há uma diferença entre informação e informativo. $\mathrm{O}$ autor apresenta o exemplo da lista telefônica que é um recurso informativo mesmo que ninguém adquira informação a partir de uma recuperação neste recurso.

Entra-se, nesse momento, em uma questão delicada da área, pois "Se qualquer coisa é, ou poderia ser, informativa, então tudo é, ou poderia ser, informação. Nesse caso chamar alguma coisa de 'informação’ há pouco ou nada para defini-la. Se tudo é informação, então ser informação não é nada especial" (BUCKLAND, 1991, p. 356, tradução nossa). Ser informação é situacional. A característica essencial da informação-como-coisa deve ser situacional também.

Na prática de arquivo, por exemplo, “[...] dois documentos fisicamente idênticos são considerados como diferentes se eles ocorrerem em diferentes lugares na ordem original dos arquivos" (BUCKLAND, 1991, p. 357, tradução nossa). Assim, a informação-como-coisa é significativa em dois sentidos:

(1) Abandonar situações específicas e indicar um objeto ou evento pode evidentemente ser informativo, p. ex., constituir uma evidência que é usada de um modo que afete as crenças de alguém; e (2) Desde que o uso da evidência está predito, entretanto imperfeitamente, o termo "informação" é comumente e com razão usado para denotar alguma população de objetos cuja alguma probabilidade significante de ser utilmente informativa no futuro tem sido atribuída. É nesse sentido que o desenvolvimento de coleções está preocupado com coleções de informação (BUCKLAND, 1991, p. 357, tradução nossa).

Do mesmo modo, a informação-como-processo, bem como a evidência envolvida na informação-como-processo, são situacionais. Aqui cabe ao profissional da informação refletir sobre um valor, já comentado nas páginas 29 , que perpassa a sua atuação enquanto indexador - a relevância - ou seja, o objetivo de que as representações recuperadas respondam as 
necessidades informacionais dos usuários, as quais foram materializadas no processo de busca da informação.

Seguem algumas pontuações que constituem uma síntese do pensamento de Buckland (1991):

1) Embora todos os sistemas de informação lidem diretamente com a informaçãocomo-coisa, pode-se criar alguma ordem para essa área. "As descobertas dessas artes úteis podem ser de grande significância, mas seus interesses estão primeiramente na evidência em si mesma" (BUCKLAND, 1991, p. 359, tradução nossa).

2) Sistemas de armazenamento e recuperação de informação "[...] podem lidar diretamente somente com 'informação-como-coisa', mas as coisas que podem ser armazenadas para a recuperação nas coleções reais ou virtuais variam de maneira significante" (BUCKLAND, 1991, p. 359, tradução nossa).

3) A representação do conhecimento consiste em “[...] um distinto subgrupo de informação-como-coisa e então poderia, em princípio, ser usada para identificar e definir outra classe de sistemas de informação nos quais o interesse primeiro é baseado no conhecimento representado" (BUCKLAND, 1991, p. 359, tradução nossa). Nesses casos, a informação-como-coisa “[...] está inevitavelmente com interesse, mas é somente um meio para lidar com a informação-como-conhecimento e, sendo meramente um meio, sua amplitude considerável é inimaginável” (BUCKLAND, 1991, p. 359, tradução nossa).

4) A informação-como-processo “[...] poderia também ser a base para definir uma classe de estudos relacionados à informação" (BUCKLAND, 1991, p. 359, tradução nossa), por meio de contribuições advindas da psicologia cognitiva, retórica e outros estudos de comunicação interpessoal e persuasão.

A partir da reflexão sobre a terceira pontuação ora apresentada referente à representação do conhecimento, duas vertentes podem ser delineadas a partir dos aspectos a serem representados e organizados. Assim, enquanto a vertente descritiva, ou formal, volta-se primordialmente a aspectos físicos, ligados à localização do recurso informacional enquanto substituto $^{19}$ (surrogate of knowledge, em inglês) desse conhecimento registrado e socializado, a vertente temática, ou de conteúdo, volta-se mais especificamente para o conteúdo informacional.

Com o advento das tecnologias, a representação descritiva e a temática passaram por um processo de mesclagem, visto que na representação descritiva, por exemplo, o campo de

\footnotetext{
19 "Os substitutos são registros catalográficos que ficam no lugar dos itens materiais, como os livros" (OLSON, 2002, p. 65, tradução nossa).
} 
autor (paternidade intelectual da obra) é também um conteúdo documental, pois é utilizado na recuperação da informação como tal.

Entre os autores que têm tentado descrever o processo de representação do conhecimento, destaca-se Pinto Molina (1994), que estabelece uma sequência cronológica a que chama de analítico-sintético-textual, na qual identifica três estágios consecutivos: estágio da leitura e compreensão; estágio da inferência-interpretação; e estágio da síntese. Nesse sentido, a autora identifica cinco componentes básicos necessários ao processo: o texto, o contexto, a base do conhecimento do analista, os objetivos documentais e o método de validação dos resultados.

Em relação aos processos de representação do conhecimento visando a extração do conteúdo documental, destaca-se a análise documental, indexação ou catalogação de assunto, considerando as distintas linhas teóricas das quais procedem (notadamente francesa, inglesa e norte-americana), que procuram caracterizar o universo da representação do conhecimento.

A análise documental decorrente dos conceitos oriundos de Jean-Claude Gardin, é definida como "[...] um conjunto de procedimentos efetuados com o fim de expressar o conteúdo de documentos, sob formas destinadas a facilitar a recuperação da informação" (CUNHA, 1987, p. 40), ou seja, consiste em um conjunto de operações que visam a representar o conteúdo de um documento sob uma forma diferente de seu estado original (comprimento, complexidade e apresentação), facilitando assim a recuperação deste e/ ou sua posterior localização.

Nesse sentido, seu universo abrange os processos específicos de análise (exame das partes do documento, leitura documental, identificação de termos e análise conceitual de acordo com a política de indexação e as necessidades dos usuários); síntese (processo de sumarização, seleção de termos, elaboração de enunciado de assunto e extração de conceitos/ palavras-chave) e representação (controle de vocabulário com as linguagens documentais e criação de índices).

No primeiro processo, de acordo com Milani (2007), a ênfase recai no abandono de uma concepção simplista que, durante muitos anos, foi baseada no bom senso e no bem fazer profissional, em busca de estudos interdisciplinares (p. ex.: com a Linguística, a Lógica e a Terminologia) que permitam aproximar-se de uma abordagem mais metodológica de processos como por exemplo, a Leitura Documental em que, segundo Cintra (1987, p. 36), “[...] os textos são desautentificados, na medida em que são deslocados de seus contextos naturais." Nesse sentido, a atividade do analista é permeada por seu conhecimento prévio e pela utilização de estratégias, pois “[...] enquanto o conhecimento prévio viabiliza, por força 
de esquemas, uma leitura mais rápida, as estratégias, especialmente as metacognitivas, conduzem à eficácia da tarefa" (CINTRA, 1987, p. 36).

Diferentemente da análise da forma de um documento com fins de representação e individualização, a representação do conteúdo documental refere-se ao conjunto de processos, instrumentos e produtos destinados a representar tematicamente o documento. Os processos que envolvem a OC são: análise documental (análise, síntese e representação) e classificação, os quais utilizam as linguagens documentais enquanto instrumentos (ou ferramentas $)^{20}$, e por meio dos quais são gerados produtos, como: índices, resumos e notações de classificação.

Os referidos instrumentos são denominados linguagens documentais e estão presentes em dois momentos do ciclo documental: entre a produção e a $\mathrm{OC}$ e entre a $\mathrm{OC}$ e a recuperação.

\subsection{Linguagens documentais}

A respeito das linguagens documentais, que são vocabulários controlados, ou seja, linguagens não-naturais ou linguagens artificiais construídas de modo a estabelecer os descritores permitidos e seus relacionamentos para representar o conteúdo documental em um âmbito geral ou de um domínio específico, Cintra et al. (2002, p. 35) explica que:

[...] diferentemente da LN [linguagem natural], o sistema de relações das LDs [linguagens documentais] não é virtual, bem como seus mecanismos de articulação são extremamente precários, em face daqueles existentes nas línguas em geral. Bem ao contrário, elementos dessa linguagem específica são selecionados de universos determinados e seu sistema de relações é construído, sendo indispensável, para utilizá-la, a existência de regras explícitas. Por esse motivo, as LDs [linguagens documentais] são linguagens construídas.

Discutem-se os parâmetros utilizados para a construção, validação e avaliação das linguagens documentais, bem como os preconceitos materializados nelas mesmas e nos

\footnotetext{
${ }^{20}$ As linguagens documentais “[...] não se confundem com léxicos, vocabulários, nomenclaturas e terminologias, embora incorporem elementos de todos eles” (CINTRA et al., 2002, p. 38).
} 
substitutos do conhecimento gerados a partir delas e de que maneira se dá esse processo no caso dos grupos marginalizados ${ }^{21}$ pela atual sociedade (MILANI et al., 2009).

As linguagens documentais atuam, então, como pontes ${ }^{22}$ entre o recurso informacional e o usuário a partir de "[...] uma normalização léxica, umas relações semânticas e uns critérios de ordenação a priori que permitem outorgar um ou vários lugares inequívocos a descrição bibliográfica em virtude dos pontos de acesso utilizados pelo usuário e o sistema" (CARO CASTRO; SAN SEGUNDO MANUEL, 1999, p. 102, tradução nossa).

Para isso, há a eleição de termos, a estruturação das classes, as relações entre os termos a partir de "[...] princípios claros, lógicos e consistentes desenvolvidos na prática bibliotecária e obtidos em manuais, normas e diretrizes" (CARO CASTRO; SAN SEGUNDO MANUEL, 1999, p. 102, tradução nossa).

Cintra et al. (2002, P. 35-36) baseadas nas obras de Jean-Claude Gardin ensinam que uma linguagem documental deve integrar três elementos básicos:

- um léxico, identificado como uma lista de elementos descritores, devidamente filtrados e depurados;

- uma rede paradigmática para traduzir certas relações essenciais e, geralmente estáveis, entre descritores. Essa rede lógico-semântica, corresponde à organização dos descritores numa forma que, latu sensu, poder-se-ia chamar classificação; e - $\quad$ uma rede sintagmática destinada a expressar as relações contingentes entre os descritores, relações que são válidas no contexto particular onde aparecem. A construção de "sintagmas" é feita por meio de regras sintáticas destinadas a coordenar os termos que dão conta do tema.

Em relação à seleção e à representação léxica dos conceitos, há três princípios que deveriam orientá-las, sendo eles: o princípio de justificação baseado no conhecimento: o conjunto de termos deve se adequar ao conhecimento sobre um domínio da realidade que transmite a disciplina ou disciplinas das quais tratam os documentos; o princípio de justificação baseado na literatura: os termos autorizados se derivam dentro do possível do vocabulário que aparece nos documentos presentes em um sistema de informação documental; e o princípio de justificação baseado no uso: a eleição dos termos deve levar em conta as necessidades informacionais e o léxico empregado pelos usuários habituais, e, por

\footnotetext{
${ }^{21}$ Entende-se por grupos marginalizados, indivíduos e/ ou comunidades que são tratados como se estivessem à margem da sociedade (sistema construído por seus cidadãos), em oposição a um grupo economicamente, politicamente e socialmente considerado dominante, o qual é considerado como pertencente ao centro da sociedade.

${ }^{22}$ Nesse sentido, pode-se considerá-las como linguagem intermediária ou metalinguagem (GIL URDICIAIN, 2004).
} 
tanto, os vocábulos que se pode presumir que foram utilizados inicialmente nas suas buscas no sistema de informação (ESTEBAN NAVARRO, 1997).

A linguagem documental consiste, dessa forma, em "[...] todo sistema artificial de signos normalizados, que facilitam a representação formal do conteúdo dos documentos para permitir a recuperação, manual ou automática, da informação solicitada pelos usuários” (GIL URDICIAIN, 2004, p. 17-18, tradução nossa). Assim, reconhece-se a natureza conceitual da linguagem documental.

Apresentam-se, abaixo, elementos que compõem as linguagens documentais, extraídos da compilação de Austin e Dale (1993) e Gil Urdiciain (2004):

- $\quad$ Descritor (ou Termo preferido);

- $\quad$ Não descritor (ou Termo Não-preferido);

- $\quad$ Notas de escopo ou Nota Explicativa ou Definição;

- Relação associativa: sintagmática (disciplina e seu objeto de estudo; processo e seu agente ou instrumento; ação e seu resultado ou produto; ação e seu sujeito passivo, conceitos ou produtos e suas propriedades; conceitos relacionados com suas origens; conceitos ligados por dependência casual; objetos e seus contra-agentes; conceitos e suas unidades de medida) (Termo Relacionado);

- $\quad$ Relação de equivalência (USE/ Usado Para);

- Relação hierárquica: paradigmática (situações lógicas: relação genérica gênero/ espécie; Relação partitiva - todo/ parte; Relação enumerativa - geral/ específico, comum/ nome próprio) (Termo Genérico ou Termo Geral/ Termo Genérico Maior/ Termo Genérico Partitivo/ Termo Específico/ Termo Específico Partitivo).

As linguagens documentais podem ser dos seguintes tipos:

- $\quad$ Classificações hierárquicas (termos associados ou equivalentes);

- $\quad$ Listas de cabeçalhos de assunto (a organização hierárquica é imperfeita, pois não se diferenciam as relações hierárquicas e associativas nem se esclarecem os critérios para definir as vinculações); e

- Tesauros (estrutura semântica desenvolvida). 
O sistema de classificação consiste, então, em uma "distribuição sistemática de conceitos em diversas categorias ou classes, de maneira que cada disciplina tenha um lugar predefinido. Trata-se de uma linguagem codificada de forma numérica, alfabética ou alfanumérica que pretende ser a descrição sintética do conteúdo dos documentos" (GIL URDICIAIN, 2004, p. 26, tradução nossa). Apresentando caráter enciclopédico, o sistema de classificação (ou seja, estrutura de classificação) tem função tanto de descrição do conteúdo documental tópico, quanto de ordenação dos recursos informacionais.

Segundo Gil Urdiciain (2004), as classificações podem ser denominadas a partir: do seu conteúdo (enciclopédicas; ou especializadas); e de sua estrutura (enumerativas; por facetas; ou mista).

Já a lista de cabeçalho de assuntos é uma “[...] linguagem pré-coordenada, de estrutura associativa ou combinatória que consiste em listas alfabéticas de palavras ou expressões da linguagem natural capazes de representar os temas de que trata um documento" (GIL URDICIAIN, 2004, p. 29, tradução nossa).

E, por fim, o tesauro é uma “[...] linguagem pós-coordenada de estrutura combinatória, constituída por listas estruturadas de conceitos - descritores - que possibilitam a descrição analítica de conteúdo dos documentos" (GIL URDICIAIN, 2004, p. 27, tradução nossa). O controle terminológico de um tesauro é muito alto e sua especificidade também pode ser, desse modo essa linguagem torna-se uma grande aliada à etapa de recuperação da informação.

Em relação ao controle vocabulário que compõe a linguagem documental, concorda-se com Gil Urdiciain (2004), quando os define como: não-controlado/ livre/ natural (p. ex.: lista de descritores livres; palavras-chave) ou controlado (p. ex.: esquema de classificação; tesauro; lista de cabeçalhos de assunto etc.).

Toda linguagem documental controlada é construída com propósitos e normas específicas, o que garante um maior controle na representação e acesso, mas, atualmente, com o advento das tecnologias de informação e comunicação há uma maior utilização de descritores livres ou da submissão destes a um controle pós-coordenado.

Gil Urdiciain (2004) explica, ainda, que os critérios de caracterização das linguagens documentais são:

- Controle (ausente: lista de descritores livres; ou presente: classificação, tesauro etc.);

- Coordenação (pré-coordenada - a relação gramatical entre os descritores é estabelecida na elaboração da linguagem: classificação, lista de cabeçalhos de assunto; ou pós-coordenada - a relação lógica entre os descritores é estabelecida durante o 
processo de busca e recuperação da informação: lista de descritores livres, lista de palavras-chave, tesauro); e

- $\quad$ Estrutural (hierárquica: sistema de classificação hierárquico; ou combinatória: léxicos documentais, tesauro).

O processo de representação do conhecimento a partir das linguagens documentais dispõe de regras explícitas e imprescindíveis à sua aplicação, de modo a evitar biasses, a partir de fenômenos linguísticos tais como os destacados por Cintra et al. (2002): ambiguidade (uma palavra pode ter plurisignificação - fenômeno específico da área semântica): polissemia (uma palavra pode ter plurisignificação - fenômeno específico da área vocabular) e homonímia (uma mesma forma significante remete a duas realidades vocabulares diversas, seja como identidade fônica 'homofonia' ou como identidade gráfica 'homografia'); $\underline{\text { sinonímia }}^{23}$ (relação de equivalência entre, ao menos, duas palavras); hiponímia (relação

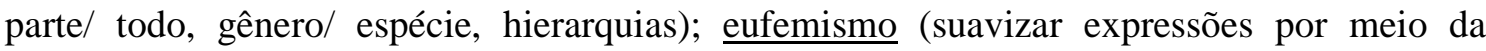
substituição de conceitos) e línguas diferentes.

Nesse momento, há de se recordar à ponderação de Cintra et al. (2002, p. 35) no sentido de que cada linguagem "[...] representa um ponto de vista particular sobre a realidade [...] e o significado de cada um de seus elementos vai estar diretamente subordinado às definições correspondentes aos elementos colocados nas posições superiores do sistema", ou seja, a linguagem documental isola e rotula uma evidência.

Assim, os sistemas de conceitos têm limites e condicionamentos, como: "[...] sua relatividade temporal e espacial, seu determinismo temático, a lógica particular que imprime o objetivo que se almeja, os esquemas cognitivos e o nível de discurso aceitável [...] para seus destinatários, questões regulamentares ou políticas de classificação etc.” (BARITÉ, 2001, p. 52-53, tradução nossa). Em suma, conceitos e categorias têm historicidade.

Desse modo, enquanto a língua é dinâmica, a linguagem documental é criada muitas vezes, como algo categórico e definitivo. Por isso, é imprescindível lembrar que:

[...] a utilização de unidades retiradas da LN [linguagem natural], dá às LDs [linguagens documentais] um caráter particular que as torna, de certa forma, diferentes dos sistemas estáticos. Na sua utilização há como que uma contaminação da mobilidade da LN [linguagem natural], passada via escolhas lexicais que se transformam em unidades documentárias. Assim, as LDs [linguagens documentais] não se livram completamente de interferências culturais que acabam por exigir um trabalho quase permanente de atualização (CINTRA et al., 2002, p. 15-16).

\footnotetext{
${ }^{23}$ Destaca-se o fato de que a sinonímia entre diferentes dialetos deve ser sempre salientada, de forma que usuários de diferentes culturas e localidades sintam-se contemplados pelo esquema de representação.
} 
Essa necessária atualização se dá a partir de políticas de gestão de linguagens documentais, aspecto ainda incipiente na realidade brasileira, pois, apesar de haver atualização das linguagens documentais, conforme se vê no quadro no apêndice A, não há uma regularidade das mesmas, nem ao menos a divulgação de parâmetros para que ocorram. Por esse motivo, viu-se a necessidade de oferecer subsídios para o universo da gestão das linguagens documentais, enquanto pontes para discussões posteriores.

Para complementar essa reflexão ressalta-se as pontuações do linguista estruturalista francês Émile Benveniste (1902-1976) em suas duas obras sobre Problèmes de linguistique générale (Problemas de Linguística Geral, em português) no tocante a complexa dinamicidade da linguagem natural.

No tocante a linguagem documental, ressalta-se o livro Para entender as linguagens documentárias (CINTRA et al., 2002), enquanto um guia completo sobre esses instrumentos de representação do conhecimento.

Uma vez representada e armazenada, a informação (enquanto insumo que compõe o conhecimento registrado e socializado) será objeto de busca e recuperação para posterior acesso e disseminação.

A recuperação da informação atua, desse modo, como um processo de comunicação, ou seja, “[...] usuários de um sistema ou serviço de informação podem encontrar os documentos, registros, imagens gráficas, ou sons gravados que vão ao encontro das suas necessidades ou interesses" (MEADOW et al., 2007, p. xv, tradução nossa).

Dessa maneira, ao rotular um documento cria-se por meio de processos, instrumentos e produtos, que não são neutros, mas, sim, construídos e convencionados, um rótulo, o qual atuará como substituto do conhecimento, como um simulacro desse documento. E será por meio desse rótulo (OLSON, 2002) ou informação-como-coisa (BUCKLAND, 1991), que o usuário terá acesso à informação desejada, utilizando-se, para isso, o processo de busca e recuperação de informação.

Em síntese, destaca-se um metavalor da CI - acesso e apropriação da informação - ou seja, a mediação entre o coletivo de informações - produção - e o coletivo de usuários - uso -, interagindo em um contexto social de OC, ou seja, permeado por elementos multiculturais e diretrizes advindas dos Direitos Humanos, a partir da representação do conhecimento. 


\section{ASPECTOS ÉTICOS EM REPRESENTAÇÃO DO CONHECIMENTO}

É exatamente no cenário de competência profissional e informacional que os estudos relacionados aos aspectos éticos ${ }^{24}$ envolvidos nas atividades de representação do conhecimento se tornam essenciais, atualmente, na área de CI, contribuindo fortemente para a preservação e disseminação da memória cultural, como salienta Olson (1998). Retoma-se que a representação do conhecimento visa à criação de substitutos do conhecimento, enquanto simulacros do documento original (livros, artigos, partituras etc.), tal como a foto que consta no documento de identidade atua em determinadas ocasiões como um simulacro, um substituto de seu portador.

A presente pesquisa optou por abordar a questão feminina e, pode-se dizer, a OC a partir da Ética, enquanto uma reflexão acerca da moral, ou seja, refletir com um olhar crítico acerca de uma realidade específica datada, localizada e construída. Parte-se, desse modo, de uma trajetória investigativa que se iniciou com a reflexão dos aspectos éticos que envolvem as dimensões profissional, pedagógica e investigativa na área da Biblioteconomia no Mercosul, incluindo reflexões sobre os códigos de ética profissional do bibliotecário (GUIMARÃES, 2003); a partir da qual viu-se a necessidade da análise dos valores e problemas morais que envolvem especificamente a representação do conhecimento, seus processos e instrumentos (GUIMARÃES, 2006a, PINHO, 2006, MILANI, 2007); e encontra-se atualmente refletindo sobre como determinados domínios do conhecimento são representados nos instrumentos, ou seja, nas linguagens documentais utilizadas pelos bibliotecários.

Nesse contexto ético, os valores adquirem a condição de normas, princípios ou padrões eleitos por uma sociedade (só os atos humanos conscientes e voluntários possuem valores), que não funcionam como universais (mas alguns possuem extensão global) e partem das raízes culturais de cada sociedade, que os julgam moralmente (reflexão ética) e então são admitidos e respeitados por estes cidadãos. Construídos ao longo da história de cada indivíduo, os valores refletem as diferentes etapas de desenvolvimento do ser humano social.

Em relação à atuação dos profissionais da informação, Froehlich (1994, p. 460, tradução nossa) destaca que existem oito grupos de fatores que afetam as decisões éticas, sendo eles: (1) utilidade social, (2) responsabilidade social, (3) sobrevivência organizacional,

\footnotetext{
${ }^{24}$ Para efeito da presente pesquisa, tem-se por ética “[...] um saber que pretende orientar as ações dos seres humanos, enquanto a moral atua como um saber que oferece orientações concretas em casos concretos" (CORTINA; MARTÍNEZ, 2005, p. 9). Para uma reflexão mais aprofundada consultar Milani (2007).
} 
(4) sobrevivência informacional, (5) respeito por si mesmo, (6) respeito por outros indivíduos e instituições, (7) padronização comunidade-cultural, e (8) normas jurídicas.

Buscando sistematizar um pouco mais a questão da ética no exercício profissional na área da informação, Guimarães (2000a, p. 65) propõe cinco dimensões de compromissos éticos desse profissional: com o usuário, com a organização, com a informação, com a profissão e consigo mesmo, enquanto cidadão.

Essas dimensões sofrem interferências de dois $\operatorname{mitos}^{25}$ destacados por Vergueiro (1994): o mito da neutralidade (sendo este a origem de biasses na representação do conhecimento) e o mito da corporação.

O mito da neutralidade, ou seja, por muito tempo os profissionais da informação acreditaram e divulgaram a liberdade de acesso à informação com a ausência de censura e a não-interferência dos seus próprios valores morais em seus fazeres, consagrado, segundo Vergueiro (1994, p. 9), pela expressão de Foskett $^{26}$ : no politics, no religion, no moral. A literatura que ampara os estudos éticos em CI (ver lista de referências ao final do trabalho) vem discutindo e oferecendo subsídios que desmascaram essas afirmações e consolidam as promessas de ausência de censura e não-interferência do profissional como sendo mitos, pois os profissionais da informação escondiam-se atrás de uma técnica como garantia de resultados neutros e unânimes.

E o mito da corporação, que, segundo análise de Guimarães (2006b, p. 247), “[...] aponta para o papel do coletivo profissional enquanto zelador de uma ética a ele intrínseca, mas por outro lado, alerta para o perigo de uma dimensão normativa excessiva prestar-se ao corporativismo e ao acobertamento de ações consideradas antiéticas." Esse mito não assola apenas a CI, mas todas áreas do conhecimento, que utilizando a justificativa de zelar pela corporação, realiza ou acoberta ações consideradas antiéticas nesse ambiente.

$\mathrm{O}$ instrumento legal que atua como guia para as situações reais que envolvem valores e problemas éticos no cotidiano dos profissionais da informação ainda é o código de ética profissional, o qual deve buscar amparar os dilemas éticos e discutir condutas e ações inerentes a um fazer profissional.

O Código de Ética Profissional do Bibliotecário (Resolução CFB no 042 de 11 de janeiro de 2002) é um instrumento ainda excessivamente prescritivo, não apresentando subsídios para uma verdadeira reflexão ética sobre a área, mas apenas questões pontuais, no

\footnotetext{
${ }^{25}$ Entendem-se mitos, enquanto dogmas, postulados que são tomados como imperativos, como verdades absolutas. Acerca dos mitos não há reflexão nem sequer são questionados.

${ }^{26}$ FOSKETT, D. J. The Creed of the Librarian: No Politics, No Ethics, No Morals. London: Library Association, 1962.
} 
mais das vezes administrativas. Comprovação disso é o fato de que a única menção que o Código de Ética Profissional do Bibliotecário faz em relação à representação do conhecimento encontra-se no seguinte recorte:

[...] Seção IV - Das proibições

Art. 12 - Não se permite ao profissional de Biblioteconomia, no desempenho de suas funções:

[...] h) deturpar, intencionalmente, a interpretação do conteúdo explícito ou implícito em documentos, obras doutrinárias, leis, acórdãos e outros instrumentos de apoio técnico do exercício da profissão, com intuito de iludir a boa fé de outrem; [...] (CONSELHO..., 2002).

Bair (2005, p. 22, tradução nossa) ensina que um código de ética “[...] deve ser desejado e suficiente para abranger qualquer dilema ético enfrentado por catalogadores [bem como por indexadores e classificadores], deve discutir condutas e ações específicas, de modo a servir como um guia útil nas situações atuais", sendo assim o atual Código de Ética Profissional do Bibliotecário ainda não contempla a reflexão proposta pela presente pesquisa.

Nessa mesma tônica, Fernández-Molina e Guimarães (2002) analisaram dezesseis códigos de ética da área de CI e identificaram sete valores fundamentais que permeiam esses códigos de ética, que são direcionados a associações de bibliotecários, bibliotecas especiais, gerenciadores de registros, arquivistas, cientistas da informação e, gerenciadores da informação, sendo eles: 1) Os interesses dos usuários vêm primeiro; 2) Forneça serviços objetivamente, sem nenhum tipo de bias; 3) Forneça aos usuários a informação mais atualizada e precisa possível; 4) Evite a censura na seleção de materiais de informação; 5) Se existir algum tipo de censura ou filtro, informe aos usuários suas limitações; 6) Separe crenças pessoais de serviços profissionais; e 7) Mantenha a competência profissional.

Os autores concluíram que os códigos de ética dos profissionais da informação, analisados a partir dos valores estabelecidos, “[...] dirigem-se a valores éticos relacionados com a organização e representação do conhecimento com pouca especificidade, devido a tradicional separação entre as atividades de processamento e gerenciamento" (FERNÁNDEZMOLINA; GUIMARÃES, 2002, p. 491, tradução nossa).

No bojo dessa discussão, contribuiu-se por meio de estudos que comprovam a necessidade de aprofundamento do problema ético da discriminação nos instrumentos de representação do conhecimento, principalmente no que se refere à questão dos valores éticos e problemas daí decorrentes - inerentes às atividades de representação do conhecimento (MILANI, 2006, 2007). 
Dos referidos estudos foram extraídos da literatura gerada entre 1995 e 2004 pelos periódicos Journal of the American Society for Information Science and Technology JASIST, Journal of Documentation, Cataloging \& Classification Quarterly, The Indexer, Ethics and Information Technology e Knowledge Organization, valores, e consequentemente problemas, éticos que estão presentes, mas nem sempre assumidos como tais, na representação do conhecimento.

Ao se aplicar as três esferas, propostas por Guimarães (2007, p. 56), ao núcleo axiológico da referida pesquisa, deparou-se com a seguinte realidade:

a) Aqueles valores maiores (ou supravalores) que permeiam toda a atividade informacional: respeito a Privacidade, Autoria (direito autoral), Acessibilidade, Liberdade, Segurança, Equidade, Diversidade e Minimização de riscos.

b) Aqueles antes havidos como requisitos profissionais, na medida em que integram a essência do fazer profissional na área: Competência, Eficiência, Flexibilidade, Confiabilidade, Reconhecimento profissional, Atualidade, Autonomia, Consciência de poder e Cooperação.

c) Aqueles antes havidos como meras medidas de ORC, mas que hoje se integram ao universo axiológico da área: Precisão, Garantia cultural, Exaustividade, Consistência, Facilidade de uso e Hospitalidade do sistema.

Decorrendo da negativa dos valores, surgem os problemas que, de acordo com Guimarães (2007, p. 57), podem ser categorizados em dois contextos:

a) Problemas que permeiam o mundo atual: Divisão digital, Pornografia, Envio de lixo eletrônico, Substituição do profissional pela tecnologia e Violência.

b) Problemas que afetam diretamente as atividades de ORC, quando do exercício profissional: Vigilância, Censura, Falta de garantia cultural, Negligência, Direcionamento informacional, Ineficiência profissional, Má representação, Racismo, Falta de clareza, Marginalização, Crença na neutralidade, Difamação, Idiossincrasia, Inacessibilidade informacional, Terminologia preconceituosa e Traduções inadequadas.

Esses dilemas éticos encontram respaldo em Beghtol (2002a), que propõe a garantia e a hospitalidade cultural (em contraposição a garantia e a hospitalidade literária), a qual prevê que indivíduos de diferentes culturas necessitam de diferentes tipos de e caminhos para a informação ${ }^{27}$.

\footnotetext{
${ }^{27}$ Os SORC devem garantir especificidade, ou seja, “[...] fornecer acesso à informação global e localmente, em qualquer língua, para qualquer indivíduo, cultura, grupo étnico ou domínio, em qualquer lugar, a qualquer
} 
A hospitalidade cultural consiste em uma "[...] habilidade de uma notação incorporar novos conceitos e estabelecer relações semânticas e sintáticas apropriadas entre os conceitos velhos e os novos" (BEGHTOL, 2002a, p. 518, tradução nossa). Dessa maneira, os SORC estariam fornecendo diferentes caminhos para a informação desejada para diferentes usuários e comunidades a partir dos descritores e notações de classificação extraídos das linguagens documentais pelo profissional da informação como sendo os mais adequados.

Nessa mesma linha de pensamento, García Gutiérrez (2002) propõe a Epistemografia Interativa ${ }^{28}$, enquanto um "[...] novo paradigma, um conjunto teórico-conceitual transdisciplinar que auxilia na análise em relação às representações no contexto de um pluralismo de culturas e discursos" (PINHO, 2006, p. 97), em busca de uma ética transcultural de mediação. Ou seja, García Gutiérrez (2002) substitui o termo profissional da informação por mediador e afirma que este tem que ter uma visão transdisciplinar, transdiscursiva e trascultural, isto é, abordar todos os aspectos possíveis de um conteúdo documental. O autor coloca a OC como um processo de reflexão sobre o conhecimento e, destaca que a influência do mediador nesse processo ocorre tanto na etapa da representação do conhecimento, quanto na etapa da tomada de decisão.

A OC, enquanto operação, segundo García Gutiérrez (2002), não lida somente com a organização, mas também com esquemas de seleção de discurso, análises, processos de decodificação, representação e acesso a suprimentos, destacando a democracia e a propriedade pública do conhecimento em escala global, em contraposição a propriedade privada e a distribuição mercadológica. Essas operações, segundo o autor, longe de serem neutras, banais ou ascéticas, são todas profundamente mediadas.

Em uma reflexão final, o autor coloca que a doutrina positivista "[...] tem estabelecido uma concepção de mundo baseada [...] em valores errados, tais como: exclusão, competitividade, exploração, funcionalidade, sucesso e merchandising. Esses valores têm inundado nossas sociedades, mentalidades e práticas cotidianas" (GARCÍA GUTIÉRREZ, 2002, p. 521, tradução nossa). E continua, dizendo que nosso campo de pesquisa deve se livrar de hábitos da elite (a maioria imposto por uma política global de interesses mercadológicos), consumismo adotado e uma linguagem técnica não ascética, que se mantém por meio de valores, tais como: "Qualidade, Eficácia, Bem-estar ou Inovação, novos

\footnotetext{
horário e para qualquer finalidade" (BEGHTOL, 2002a, p. 507, tradução nossa). Beghtol (2002a) caracteriza o usuário, pertencente a várias culturas e em vários níveis, como multicultural, multilíngue e multidisciplinar.

${ }^{28}$ Tem-se como instrumento oriundo da Epistemografia Interativa, “[...] a linguagem epistemográfica, que assume o compromisso de representar a pluralidade, enquanto linguagem associativa. Essa linguagem é formada através de eixos paradigmáticos e sintagmáticos, valorizando as relações associativas para que, assim, nenhum tema se sobreponha aos demais" (PINHO, 2006, p. 98).
} 
postulados expandidos como indicadores de modernidade e progresso (também uma nova ética?). Todos esses conceitos podem ser reformulados por meio, principalmente, de uma perspectiva social e crítica” (GARCÍA GUTIÉRREZ, 2002, p. 521, tradução nossa).

Desse modo, a adoção de uma Epistemologia Multicultural ${ }^{29}$, enquanto uma dimensão do Multiculturalismo postulada por Semprini (1999) ou de uma Epistemografia Transcultural e Interativa, enquanto uma dimensão advinda da CI postulada por García Gutiérrez (2002) torna-se fundamental ao profissional da informação como norteador nos processos de representação e mediação de um conhecimento registrado e socializado para que o mesmo, uma vez apropriado, possa fornecer informação para a geração de novo conhecimento.

No mesmo sentido, têm-se as ideias de Hudon (1997) sobre a diversidade de valores culturais (e a necessidade de sua compatibilização) que se apresentam em tesauros multilingues.

No tocante a aplicação do Multiculturalismo nos tesauros multilingues, Hudon (1997) contribui de forma a dar um tratamento equitativo às línguas representadas nesse instrumento, através de um esquema que permite a identificação de problemas de natureza ética. Esse esquema dá suporte à construção do tesauro.

Hudon (1997) lista alguns problemas associados aos tesauros multilingues, potenciais causadores de biasses durante sua utilização para a representação do conhecimento, sendo eles: dilatação da linguagem para ajustá-la a uma estrutura conceitual estrangeira, no ponto em que esta se torna pouco reconhecível para seus próprios falantes; transferência de uma ampla estrutura conceitual de uma cultura para outra, sendo apropriada ou não; tradução literal dos termos da língua de origem para expressões sem sentido na língua alvo etc.

Hudon (1997, p. 90) apresenta, ainda, alguns pontos que devem ser pensados quando se discute linguagens documentais, como o tesauro multicultural, por exemplo. Assim, devese ter consciência das seguintes características:

- o tesauro é construído dentro de uma estrutura administrativa semicentralizada, com representantes de cada linguagem/ cultura na equipe da tomada de decisão;

- todas as versões linguísticas do tesauro são desenvolvidas simultaneamente a partir do seu estabelecimento;

- os criadores do tesauro são falantes nativos da linguagem que trabalham, com um bom conhecimento da outra linguagem envolvida;

\footnotetext{
${ }^{29}$ A epistemologia multicultural compõe-se por várias visões teóricas, a qual postula que: a realidade é uma construção; as interpretações são subjetivas; os valores são relativos; o conhecimento é um fato político. Desse modo, “[...] existe o 'bom senso', as coisas 'como elas são' de um lado, e o Multiculturalismo de outro. A epistemologia monocultural não é compreendida como tal, mas simplesmente como a realidade sem mais" (SEMPRINI, 1999, p. 89).
} 
- distintos bancos de termos são construídos independentemente de cada linguagem com termos encontrados na linguagem dos documentos;

- $\quad$ identidade e simetria de estruturas não são exigidas acerca das várias versões linguísticas dos tesauros [, o que realça o problema das assimetrias semânticas], e equivalência individual-a-múltipla, "órfãos", e variações nas hierarquias etc. são permitidas;

- $\quad$ o uso de neologismos é muito restrito se permitido para todos;

- o desenvolvimento do software do tesauro que permita a nãoidentidade do registro de descritores e a rotação de línguas fonte e alvo usadas;

- indicadores fisicamente separados para cada uma das línguas representadas são produzidos.

De acordo com Pinho (2006, p. 105), “[...] os autores analisados são convergentes em suas opiniões em relação ao usuário, bem como complementares, em relação às competências profissionais, que abrangem o profissional e a leitura, bem como no tocante aos valores intrínsecos ao processo de representação.” Lembrando que a representação do conhecimento não preza pela satisfação informacional personalizada, ou seja, de um indivíduo, pois tal tarefa seria impraticável, mas, sim, a satisfação informacional de uma comunidade discursiva.

Essa mediação multicultural, por sua vez, assume uma efetiva complexidade na medida em que deve dedicar atenção ao momento da recepção (ou à lógica de recepção do usuário) e às possibilidades de sua "fragmentação", de tal forma que um dos desafios do Multiculturalismo reside em compreender como evitar situações de incomunicabilidade e encontrar novos terrenos de mediação e de tradução. Esse processo, por sua vez, configura-se tenso, na medida em que a diversidade pressupõe (ou ao menos não exime) o conflito.

Guimarães e Fernández-Molina (2003) realizam um estudo na revista Knowledge Organization e não encontram nenhuma menção a valores éticos, enquanto Van der Walt (2004) ressalta a presença do valor responsabilidade social na atuação dos profissionais da informação em atividades de representação do conhecimento e a necessidade da flexibilidade de suas ferramentas, bem como dos idealizadores das mesmas, para que esse valor possa ser aplicado.

Nesse sentido, Fernández-Molina et al. (2005) constatam os valores e problemas éticos relacionados às novas tecnologias de informação e comunicação, enquanto Guimarães et al. (2005) estabelecem uma comparação da literatura sobre ética do profissional da informação existente. Em contrapartida, Bair (2005), já comentada na página 43, apresenta o esboço de um código de ética, como uma alternativa para orientar as decisões éticas dos catalogadores.

Guimarães (2006b), ao abordar sob o ponto de vista histórico os aspectos éticos em ORC, ressalta mais especificamente o problema ético da discriminação. 
Todos esses marcos teóricos convergem no sentido de a representação do conhecimento refletir os valores morais de quem realiza seus processos, bem como de quem idealiza seus instrumentos e produtos, ou seja, pode ser que ocorram biasses na representação do conhecimento, pois a representação ocorre por meio da seleção de conceitos para serem nomeados, os quais “[...] definem os limites do sistema, suas inclusões e exclusões. A seleção de termos para esses conceitos, frequentemente, introduz biasses ruidosas ou, mais comumente, sutil marginalização desleal" (OLSON, 2002, p. 6, tradução nossa).

Destaca-se que o problema ético de acesso à informação, já foi salientado, mesmo que de uma maneira excessivamente estatística, por Jacques Chaumier quando destaca que "[...] um sistema documental se define pelas percentagens de ruído, silêncio e pertinência" (CHAUMIER, 1971, p. 20).

Chaumier (1971, p. 20) define o ruído como sendo “[...] a percentagem de documentos parasitas que não respondem à questão levantada e selecionados quando da interrogação, em consequência, essencialmente, de combinações acidentais de característica ou de confusões, no sentido quanto aos termos de caracterização.” Oposta à noção de ruído, segundo Chaumier (1971, p. 20), está a noção de silêncio, que é “[...] a percentagem de documentos pertinentes que respondem a uma questão existente na memória e não selecionados quando da interrogação." Sendo assim, a pertinência consiste na "[...] percentagem de documentos encontrados quando das operações de seleção e que responde à questão do inquiridor relativamente ao número total de documentos encontrados" (CHAUMIER, 1971, p. 20).

López-Huertas (2008b) sugere que as questões éticas compõem um importante tópico emergente em OC que não tem sido abordado pelos acadêmicos com a mesma intensidade que outros tópicos.

\subsection{Bias: o início de uma reflexão}

Há a necessidade de se estudar cada disciplina dentro de um domínio do conhecimento em determinado espaço e tempo com o objetivo de construir efetivos SORC. Em uma interação com um sistema de busca e recuperação da informação com biasses, o usuário pode sentir que sua autoimagem retransmitida - por meio de palavras, conceitos, atitudes, comportamentos - “[...] é uma imagem desvalorizante, discriminatória, ou até agressiva [...] A depreciação sistemática, afirmam os multiculturalistas, afeta pesadamente a autoestima de um 
indivíduo e acaba sendo interiorizada e instalada no âmago de sua identidade" (SEMPRINI, 1999, p. 105). Assim, não se sentir refletido por uma representação do conhecimento denuncia que esta foi construída sob bias.

Há na literatura muitos argumentos relativos à problemática biasses (nem sempre assim denominada) na representação do conhecimento presente no cerne da área de CI, que se apoia na máxima representar para recuperar (ou como prefere Smit (1986): "reunir e organizar para achar"). Desse modo, tem-se os preconceitos que podem embutir-se na estruturação de linguagens documentais (p. ex.: estabelecimento das relações de equivalência e hierárquicas em um tesauro) e, por conseguinte, nos índices. Tal aspecto, “[...] além de ferir direitos individuais, inibiria o usuário, alijando-o do sistema de informação, por absoluta falta de confiança e mesmo de identificação com os critérios de representação [...]" (GUIMARÃES, 2006b, p. 238).

Bias, segundo Hjørland (2008a, p. 256, tradução nossa), “[...] é normalmente entendida como uma palavra negativamente carregada, enquanto algo a ser evitado ou minimizado, por exemplo, em estatística ou em organização do conhecimento."

Olson (2002), a partir de uma contextualização a respeito da criação de substitutos do conhecimento (denominada o poder de nomear ${ }^{30}$ ) insere a seguinte constatação: "Toda nomeação é necessariamente construída sob bias e o processo de nomear é o que codifica essa bias, fazendo a seleção do que enfatizar e o que deixar passar baseado no uso estrito dos materiais padronizados prontos" (SPENDER, 1985, p. $104^{31}$ citado por OLSON, 2002, p. 4, tradução nossa).

López-Huertas Pérez e Torres Ramírez (2005) alertam, ainda, que todo tipo de bias presente no léxico responde a uma construção ou a um prejuízo social, seja de caráter político, filosófico, religioso, étnico etc. Têm-se, dessa maneira, interpretações mediadas por uma realidade social subjetivamente interpretada.

Brey (1999) atribui aos produtores/ programadores de jogos de realidade virtual, por exemplo, a responsabilidade sobre as consequências geradas a partir da temática abordada e representações utilizadas nos seus jogos (p. ex.: como os bandidos são representados e como os pertencentes ao grupo dominante são representados), e acrescenta que a representação é uma tomada de decisão constante e deve ser fidedigna (ou defensável), ou seja, “[...] quando o

\footnotetext{
30"Nomear é a ação de conceder um nome, de rotular, de criar uma identidade" (OLSON, 2002, p. 4, tradução nossa), a partir de um cabeçalho de assunto ou um número de classificação, por exemplo. A autora explica que nomear é um meio de comunicação interpessoal via linguagem que controla a representação do conteúdo documental e, consequentemente, seu acesso.

${ }^{31}$ SPENDER, D. Manmade Language. London: Routledge and Kegan Paul, 1985.
} 
emprego da realidade virtual está favorecendo certos valores ou interesses a outros devido a uma representação tendenciosa, pode-se dizer que o modelo fez uso de uma biased representation" (BREY, 1999, p. 12, tradução nossa).

O autor diferencia, então, misrepresentation (alguns aspectos da representação encontram-se claramente errados de acordo com os padrões de exatidão estabelecidos) e biased representation (os valores e os interesses de alguns usuários da representação não são contemplados) e conclui que metodologias devem ser desenvolvidas para que essas biasses sejam constatadas e prevenidas. Biasses na realidade virtual são perceptíveis por se tratar de simulações da realidade, o que não acontece tão evidentemente na representação do conhecimento.

Biasses são problemas éticos que, no mais das vezes, levam à reflexão dos valores da área e Olson (2002) reitera tal conceito quando constata que as influências de algumas linguagens documentais, tais como a LCSH e a CDD são enormes causando, assim, uma "compatibilidade universal" e a perda da autonomia cultural. Pode-se, assim, dizer que as biasses não estão limitadas a descrições individuais, há biasses relacionadas a "[...] gênero, sexualidade, raça, idade, habilidade, etnicidade, linguagem e religião, [as quais] têm sido descritas como limites para a representação da diversidade e para os efetivos serviços biblioteconômicos para populações diversas" (OLSON, 2002, p. 7, tradução nossa).

Buscando analisar como os padrões de acesso por conteúdo representam grupos e tópicos marginalizados, Olson e Schlegl especificam três problemas:

primeiro, satisfazer a maioria dos usuários da biblioteca algumas vezes resulta em uma representação de assunto sob biasses; segundo, tentativas de objetividade podem resultar em tratamento igualitário quando o que é exigido é um tratamento equitativo para acomodar as diferenças; e terceiro, que padrões homogeneízam os resultados da catalogação e, então, impõem uma linguagem universal em diversos contextos (OLSON, 2002, p. 9, tradução nossa).

Desse modo, o primeiro quesito esbarra com a real prática profissional e o tempo que os bibliotecários têm para realizar as tarefas de análise documental e classificação. O segundo quesito é delicado uma vez que a linguagem documental tenta incluir determinados aspectos de um domínio do conhecimento ou comunidade discursiva e muitas vezes acaba ressaltando determinado preconceito. Por sua vez, o terceiro quesito é, primeiramente, um objetivo almejado pela Documentação, ou seja, deixar juntos recursos documentais congêneres e isso se dá apenas a partir de linguagens documentais. 
Os problemas de biasses nas linguagens documentais hierárquicas, por exemplo, “[...] podem ser ligados à natureza da classificação como uma construção social. Eles refletem as mesmas biasses da cultura que a criou" (OLSON, 1998, p. 233, tradução nossa). Sendo assim, como salienta A. C. Foskett, em 1971, “[...] os classificadores são produtos de seus tempos” (OLSON, 1998, p. 234, tradução nossa).

Nesse mesmo caminho e buscando apontar preconceitos, Berman (1993) examina não somente os cabeçalhos da LCSH com biasses, mas também descritores relativos às pessoas mais velhas, pessoas deficientes, as denominadas minorias sexuais, mulheres e pessoas pobres, bem como o contexto de produção da própria Library of Congress. O autor acrescenta que há uma decadência em relação à criação e uso imediato de cabeçalhos para pessoas tópicos relacionados que surgem atualmente (em livros ou em outras mídias); nomeação proveitosa de cabeçalhos que já são utilizados (por meio da catalogação mínima ou escondendo informações); e por não haver uma publicação corrente de notas públicas que clareiem o escopo e o significado de tópicos novos ou não utilizados (como já ocorre na Henniping Country Library, Minnessota, Estados Unidos) $)^{32}$.

De acordo com pesquisa realizada por Olson (1998), os problemas de coextensividade $^{33}$ foram constatados, por meio das metodologias de análise feminista e pósestrutural, no tratamento de conteúdos documentais na perspectiva de gênero sugerida pelo tesauro feminista $A$ women's thesaurus ${ }^{34}$, o qual exige o acesso de coextensividade separadamente, ora geral, ora de gênero. A reunião e proximidade entre os conceitos e as definições das notações criaram ambientes estranhos e, até mesmo não amigáveis.

Têm-se, então, variáveis que influenciam a criação voluntária ou não de biasses, sendo elas causadas a partir: da representação temática do conhecimento; da representação descritiva do conhecimento; do profissional da informação indexador; do próprio documento ou da natureza do conhecimento registrado; das linguagens documentais; da política de indexação (ou da falta dela); da política de seleção e uso; do profissional da informação mediador; ou do usuário durante o processo de busca e recuperação da informação. Destaca-se que a presente pesquisa elegeu as instâncias representação temática da informação e linguagens documentais para análise e discussão uma vez que cada instância citada acima é passível de análises profundas e já há resquícios na literatura referentes a cada uma delas.

\footnotetext{
${ }^{32}$ Destaca-se que, atualmente, há a publicação das alterações ocorridas na LCSH que são vendidas, inclusive separadamente da linguagem documental.

${ }^{33}$ Coextensividade, segundo Olson (1998), é a representação baseada no conteúdo documental individual e não baseada na estrutura do sistema.

${ }^{34}$ CAPEK, M. E. S. A women's thesaurus. New York: Harper \& Row, 1987.
} 
Os profissionais da informação devem compreender, conforme atesta Hjørland (2008a, p. 258, tradução nossa), que “[...] contribuições para a produção, uso e organização do conhecimento não podem ser feitas a partir de posições neutras, fora do esforço do interior dos domínios", o que envolveria diretamente a epistemologia do mesmo elaborada a partir da literatura gerada por seus especialistas.

Há algumas críticas a essa base metodológica de criação de fronteiras a partir de descobertas científicas, assim como a existência de múltiplos paradigmas ${ }^{35}$ dentro de um domínio e não de múltiplos domínios (FEINBERG, 2007), mas Hjørland (2008a) defende essa metodologia quando afirma que as disciplinas são dinâmicas e dependentes da teoria, e que o conhecimento do conteúdo documental é necessário, embora insuficiente, sendo assim os especialistas ou profissionais da informação precisam de outros conhecimentos acerca do contexto em que o domínio será representado.

Esse tema foi, também, discutido em Olson (2002, p. 30, tradução nossa), quando criticando a CDD a autora afirma: “[...] Dewey não invoca a garantia literária (o uso de tópicos utilizados em publicações existentes para justificar a inclusão de tópicos em um vocabulário controlado) em qualquer ponto", ele invoca a sua representação de mundo.

Em relação aos domínios que envolvem grupos marginalizados, López-Huertas (2006, p. 223, tradução nossa) ressalta que “[...] os especialistas driblam essa falta de linguagem acrescentando uma expressão inequívoca da interdisciplina, como gênero, mulheres etc., assim é a disciplina ou a temática que estabelece os limites do discurso de gênero", por exemplo. A autora exemplifica esse fato citando alguns conteúdos documentais tópicos: mulher e política; salários das mulheres; direitos sociais das mulheres; saúde e gênero etc.

Essa atitude faz com que a representação seja feita sob biasses, uma vez que “[...] ambientes sócioculturais afetam a orientação temática das Especialidades. Uma parte importante do conhecimento que vem sendo produzido está respondendo às demandas socioculturais [...]" (LÓPEZ-HUERTAS, 2008a, p. 345, tradução nossa), sendo necessária uma representação que assegure a garantia cultural a essas mulheres.

A preocupação com as diferenças culturais deve, então, fazer parte do planejamento, construção, gestão e avaliação dos SORC. Uma alternativa já apresentada anteriormente é analisar determinado domínio do conhecimento em cada cultura, como se está fazendo aqui, isto é, como a questão feminina está sendo representada a partir das linguagens documentais brasileiras.

\footnotetext{
${ }^{35}$ Ver o conceito de paradigma adotado pela pesquisa em nota na página 27.
} 
Essa preocupação surge, pois o poder de rotular do profissional da informação (OLSON, 2002) lhe autoriza a construir percepções e discursos. Então, “[...] qualquer aplicação de conceitos e qualquer OC, dessa forma, tem que considerar quais definições e relações semânticas são propostas no contexto dado" (HJØRLAND, 2008a, p. 260, tradução nossa), ao contrário do que propõem as ideias de "universalização" e "padronização" muito difundidas na área de CI. Assim, "Nós [bibliotecários] decidimos o que nomear e o que deixar sem nome" (OLSON, 2002, p. 4, tradução nossa).

Desse modo, rotular a informação a partir da criação de substitutos do conhecimento não é apenas um processo de representação do conhecimento, mas a construção desse conhecimento.

Visando exemplificar a discussão apresentada, partiu-se das instâncias de biasses propostas por Guimarães (2006a) para buscar exemplos das mesmas na literatura (ver lista de referências ao final do trabalho) e, então, apresentar a seguinte categorização de biasses na representação do conhecimento:

- Relativo ao preconceito ou discriminação, seja no momento da análise ou da representação;

Por exemplo: Lesbianismo USE Desvios sexuais poderia levar ao constrangimento de uma parcela da comunidade usuária.

No tocante as biasses inerentes a CDU, Santos, Madina e Serra (1999) destacam: Discriminação de gênero (Nas notações referentes: as profissões; ao direito penal; a administração pública; ao feminismo); Discriminação sexual (Nas notações referentes: ao sexo e as pessoas; a pornografia; a higiene e vida sexual; a saúde e higiene da mulher); Tabus sociais (Nas notações referentes: a higiene e a moral; ao direito e a pornografia; aos problemas que afetam o bem-estar social); Discriminação imperialista - relações Norte-Sul dos países - (Nas notações referentes: ao desenvolvimento dos povos; as raças; a como se fala um idioma); Discriminação de minorias (Nas notações referentes: as minorias; aos asilos para mendigos).

Em relação a LCSH, Berman (1993) apresenta algumas biasses e sua situação - alguns solucionados e outros não - conforme se segue: Jewish question - 13 anos para ser abolido; Yellow Peril - 18 anos para ser abolido; Race question substituído por Race 
relations; Negroes substituído por Afro-americans; Rogues and vagabonds SEE ALSO Gypsies - desvinculados; Sexual perversion SEE ALSO Homosexuality and Lesbianism - abolido; Women as... Ex: Women as accountants compactado por Women accountants; Children - management substituído por Child rearing; Primitive - permanece; Oriental (na maioria das vezes representando o Asian) desfavorece, por meio do termo Orient, os Asian-americans - permanece; Romanies (or Roma) - termo preferido - Nenhum outro cabeçalho ampara as experiências durante o Third Reich, o que também ocorre com os Jews; Class K - Laws - Nas décadas de 60 e 70 foram publicados volumes separados para cada país norte-americano e europeu, sendo que apenas em 1993 foi publicado um volume englobando a Ásia, Eurásia, África, Área do Pacífico e Antártida (OLSON, 1998); Sand Creek Massacre, 1984 - Aqui entram materiais de 29 de novembro de 1864, quando ocorreu o massacre dos Cheyenne Indians, do Sand Creek, Colorado, pelas tropas estado-unidenses comandadas pelo coronel John Chivington; Hate Crimes - Aqui entram materiais de ações criminais que envolvem indivíduos ou grupos em casos com vítimas de sexo, raça, cor, religião, orientação sexual, deficiência, idade ou nacionalidade de origem - Por exemplo: Terrorismo e ações violentas, incluindo incêndio, bombardeamento de casas e negócios, cross burning, vandalismo (como desenhos swastika), assaltos a pessoas, telefonemas inoportunos ou obscenos e cartas e pacotes ameaçadores; Zouk Music Aqui entram músicas de dança caribenha em combinação com as cantigas do Oeste da Índia, ritmos africanos e pop ocidental.

- Relativo às categorizações dicotômicas nos sistemas de classificação, as quais decorrem de uma tradição aristotélica de oposição de conceitos e, quando adotadas de forma categórica, podem evidenciar desrespeito entre diferentes culturas, reforçando a ideia de preponderância ou revelando de certa maneira proselitismo;

Por exemplo: Religiões cristãs X Religiões não-cristãs, reforçando um paradigma de preponderância ou de normalidade.

Na CDD (OLSON, 1998), por exemplo, no tocante a Religion (classe 200) onde $80 \%$ da classe são dedicados exclusivamente ao Cristianismo e a American Literature (classe 810) como seção separada, enquanto a Literatura proveniente de outras nações se encontra na seção Languages. 
- Relativo à visão de mundo específica, uma vez que em algumas linguagens documentais se priorizam alguns conceitos em detrimento de outros;

Por exemplo: algumas classificações, notadamente norte-americanas, como a CDD, que em alguns aspectos revelam uma concepção de mundo pautada pelo prisma do WASP (White, Protestant and Anglo-Saxon Man).

- Relativo à precisão terminológica na representação documental;

Por exemplo: substituição da expressão igrejas protestantes por igrejas evangélicas, caracterizando uma metonímia, visto que toma a parte pelo todo uma vez que todas as igrejas cristãs (e que, portanto, valem-se das escrituras do Novo Testamento e, portanto, dos evangelhos) poderiam ser assim denominadas. Essa questão passa por aspectos nitidamente políticos e sociais, como se pode observar em países latinoamericanos, onde a expressão evangélico encontrou mais força com o surgimento das igrejas neopentecostais que passaram, então, a abrigar-se sob tal denominação, juntamente com as igrejas reformadas tradicionais, revelando um suposto gênero cujas espécies, por guardarem distinções doutrinais substantivas, não poderiam ser simplesmente consideradas como tais.

- Relativo à polissemia de alguns termos técnicos, sem que, muitas vezes, o profissional se dê conta de tal fato;

Por exemplo: o termo Classificação que, embora nas áreas de Arquivologia e de Biblioteconomia revele igualmente a preocupação final com a ordenação documental, pauta-se por lógicas distintas, qual seja, a funcional, na primeira, e a temática, na segunda.

- Relativo à dimensão do "politicamente correto" na indexação, quando ao longo do tempo, expressões evoluem e adquirem maior precisão;

Por exemplo: Usuários deficientes, Usuários portadores de deficiência, e posteriormente Usuários especiais, e atualmente, Usuários com necessidades especiais. 
Uso preferencial do termo homossexualidade ao invés de homossexualismo, uma vez que o sufixo -ismo, deste último, leva a ideia de vício, assim como em tabagismo, alcoolismo etc.

Extraiu-se da literatura de Biblioteconomia dois pontos para futuras comparações com o problema ético biasses, sendo eles: o vértice: "[...] o vértice de cada hierarquia é o gênero ou o todo [...]" (CINTRA et al., 2002, p. 44), ou seja, sob o mesmo termo têm-se especificidades; e as assimetrias semânticas (HUDON, 1997).

\subsection{Pontuações sobre a não-neutralidade}

A partir da reflexão do levantamento teórico e dos exemplos apresentados, destaca-se como alternativa para a garantia cultural na OC (BEGHTOL, 2002a), a abordagem da análise de domínio que, conforme atesta Hjørland (2008b), foi formulada como uma alternativa para a visão cognitiva dominante na BCI.

A análise de domínio é

[...] um ponto de vista sociológico-epistemológico. A indexação de um dado documento deveria refletir as necessidades de um dado grupo de usuários ou um dado propósito de ideal. Em outras palavras, qualquer descrição ou representação de um dado documento está mais ou menos ajustada para o cumprimento de certas tarefas. Uma descrição nunca é objetiva ou neutra, e o objetivo não é padronizar as descrições ou fazer uma descrição uma vez e para todos para diferentes grupos-alvo (HJØRLAND, 2008b, p. 95, tradução nossa).

Desse modo, diferentes pontos de vista ou diferentes domínios necessitam de diferentes SORC amparados pela hospitalidade cultural $^{36}$, conforme demonstrado a seguir.

A análise de domínio é "[...] a única abordagem da OC que tem examinado seriamente as questões epistemológicas no campo, p. ex. comparando as suposições feitas em diferentes abordagens para a OC e examinando as questões considerando a subjetividade e objetividade na OC" (HJØRLAND, 2008b, p. 95, tradução nossa).

A representação do conteúdo documental "[...] é feita de modo a levar os usuários a fazer discernimentos relevantes. Os documentos deveriam ser olhados com os olhos dos

\footnotetext{
${ }^{36}$ A respeito da hospitalidade cultural, ver página 45.
} 
usuários potenciais" (HJØRLAND, 2008b, p. 95, tradução nossa). Então, a análise de domínio supõe que “[...] diferentes abordagens (ou 'paradigmas') existem em todos os domínios do conhecimento e têm que ser identificadas. Elas não são uniformemente distribuídas na literatura ou entre os usuários, que é o porquê de os modelos representativos não poderem ser usados" (HJØRLAND, 2008b, p. 96, tradução nossa).

Hjørland (2002, p. 425, tradução nossa), pontua que "Tesauros são, principalmente, vocabulários de um domínio específico e a metodologia para projetá-lo pode ser vista, também, como uma forma (implícita) de análise de domínio." Nesse mesmo sentido, as “Classificações são, assim, intimamente ligadas às teorias científicas. Cursos e pesquisas em classificação bibliográfica tendem, infelizmente, a ignorar tal literatura sobre classificação científica" (HJØRLAND, 2002, p. 427, tradução nossa).

O domínio atua, desse modo, não apenas oferecendo instrumentalidade para o mapeamento de um ramo científico (disciplinas e subdisciplinas), mas, também, como reflexo de uma comunidade discursiva (p. ex.: pesquisadores, revistas, eventos de determinada área etc.).

A CI tem dado atenção à questão dos grupos marginalizados social e culturalmente, mas, em relação às questões de gênero e, mais especificamente, à questão da mulher, poucos esforços têm sido feitos. Como essas questões ainda não têm um quadro epistemológico definido, “[...] diferentes sociedades, nações e comunidades encaram temas de gênero de vários modos, levando em consideração concepções ou modelos culturais, religiosos e sociais ou a visão de mundo de uma cultura ou subcultura particular" (LÓPEZ-HUERTAS; BARITÉ ROQUETA, 2002, p. 394, tradução nossa). Desse modo, os estudos de gênero no ambiente de representação do conhecimento são, não apenas atuais, mas principalmente, necessários.

Deve-se prezar pela garantia cultural na representação do conhecimento, considerando que "[...] diferentes 'paradigmas' existem em todos os campos do conhecimento e cada [...] paradigma serve a diferentes objetivos e interesses, por essa razão sua identificação e exploração têm a mais alta prioridade para a Ciência da Informação" (HJØRLAND, 2008a, p. 260, tradução nossa).

Torna-se necessário, então, explicitar os valores, paradigmas, aspectos históricos, sociais e culturais que perpassam determinado domínio do conhecimento a fim de definir os descritores que melhor o representem em determinado espaço e tempo, bem como disponibilizar mecanismos nas linguagens documentais que possibilitem sua adequação a contextos específicos de unidades e sistemas de informação, tais como: remissivas, termos 
relacionados, referenciação, entre outros, afinal “[...] o sistema de informação é o meio pelo qual a posição no domínio é articulada" (FEINBERG, 2007, tradução nossa).

Se os profissionais da informação não forem capazes de prever ou solucionar as biasses, a mera possibilidade da existência das mesmas deve ser informada aos usuários, tentando, assim, tornarem-se mais responsáveis (hidden bias to responsible bias, conforme coloca Feinberg, 2007) face as biasses e se colocarem explicitamente sobre as perspectivas representadas em suas unidades e sistemas de informação.

Em síntese, há três níveis de biasses na representação do conhecimento: bias na indexação (processo); bias nas linguagens documentais (instrumentos); e bias nos índices, resumos e notações de classificação (produtos).

Code $\left(1995^{37}\right.$, citado por OLSON, 1998, p. 244-245, tradução nossa), faz alguns apontamentos em relação à não-neutralidade nesse contexto, os quais são destacados resumidamente a seguir: classificações não são inatas ou naturais, mas construídas por meio de uma base lógica e as mudanças, enquanto discursos, agem sobre elas; os espaços têm fronteiras (incluem e/ ou excluem alguns conceitos); um espaço retórico positivo é uma solução para que discursos marginalizados - oprimidos, colonizados, explorados - sejam ouvidos; tornar as exclusões visíveis significa identificar as fronteiras espaciais para permitir o reconhecimento do que está fora das mesmas; a representação da realidade é uma construção da realidade, assim como a representação da informação é a construção da informação; a classificação produz informação em um processo criativo, criando conhecimentos centrais e periféricos; o contexto e o processo afetam a construção da realidade, pois os autores não criam textos, estes são criados pela leitura realizada pelos profissionais da informação, usuários, instituições etc.

Relativamente à não-neutralidade dos processos de representação do conhecimento, bem como à direta ligação dessas questões com os aspectos contextuais que permeiam tanto a unidade de informação quanto o profissional, Dias, Naves e Moura (2001) alertam para a necessidade de estudos relacionados à análise de domínio terminológico, mais especificamente relacionados ao aboutness (em inglês), também conhecidos como atinência extensional, atinência ou topicalidade (conteúdo intrínseco ao documento) e atinência intensional, significado ou informatividade (conteúdo de interesse para determinados usuários e/ ou comunidades). Nesse contexto, tem-se, o aboutness como algo intrínseco ao documento, enquanto o significado é mutável.

\footnotetext{
${ }^{37}$ CODE, L. Rhetorical spaces: essays in gendered locations. New York: Routledge, 1995.
} 
Relativamente à não-neutralidade da linguagem natural e, consequentemente, das linguagens documentais, destaca-se que a linguagem testemunha uma situação de desequilíbrio da sociedade e da mesma maneira afeta profundamente as nossas representações de mundo, moldando a percepção que uma sociedade ou uma comunidade tem de si mesma.

Assim,

A linguagem é identificada não apenas como lugar onde as relações de dominação e exclusão se cristalizam, mas também onde essas relações são negociadas, produzidas e reproduzidas. De um ponto de vista cognitivo, enfim, a linguagem desempenha um papel ativo na produção da realidade, pois ela fornece o instrumental conceitual (categorias, conceitos) sem o quê a realidade - principalmente a realidade social - não seria identificável nem compreensível (SEMPRINI, 1999, p. 66-67).

De acordo com López-Huertas Pérez e Torres Ramírez (2005), quando se fala em temáticas (interdisciplinaridade) e disciplinas (modelos baseados no desenvolvimento das especialidades como expansão do domínio com claros limites epistemológicos), não há um modelo comumente aceito para a construção de linguagens documentais.

Relativamente à não-neutralidade do profissional,

Todo indexador aproxima-se de um documento com um pacote mental de atitudes, crenças, prejuízos, ideias experimentadas, "fatos", conhecimento geral e "sabedoria convencional". Muitos desses pacotes são úteis para ajudar a entender, interpretar e representar o conteúdo do documento. Algumas vezes, com documentos que são polêmicos para nomear, ou que lidam com assuntos criticamente ou polemicamente, os indexadores poderão ter que lutar com esses materiais que contrastam com suas visões pessoais. [...] Não é necessário para um indexador ser completamente a favor de alguma coisa no interior do documento, mas a indexação deve refletir e representar a forma tanto quanto o conteúdo. $\mathrm{O}$ indexador pode experimentar a distância de algumas partes dos documentos, mas isso pode não ocorrer continuamente na indexação. Embora a indexação seja um trabalho a partir de suas próprias verdades, criadas pelo indexador, e exibindo seu conhecimento geral e especialista e sua perícia técnica, não deve revelar suas crenças, atitudes e julgamentos pessoais (BOOTH, 2001, p. 36, tradução nossa).

Um dos pontos mais mascarados desse problema ético é a bias criada pelo indexador a partir de seus próprios valores morais, conforme sistematização e discussão apresentada por Guimarães et al. (2008).

No que diz respeito às inconsistências na representação do conhecimento geradas a partir do profissional, Olson (2002, p. 52, tradução nossa) conta que as preocupações de Cutter em relação ao indexador "[...] com 'ideias preconcebidas e associações acidentais' 
coincide com a preocupação de Dewey de que 'diferentes bibliotecários, ou o mesmo bibliotecário em tempos diferentes, classificam os mesmos livros ou similares em lugares amplamente diferentes'."

Em síntese, a representação do conhecimento é uma tomada de decisão constante e deve ser defensável, para tanto, está-se apresentando subsídios acerca dos estudos éticos no universo da gestão das linguagens documentais, enquanto pontes para discussões posteriores. 


\section{A QUESTÃO FEMININA}

Pour les droits des femmes contre toutes les discriminations ${ }^{38}$

Le féminisme n’a jamais tué personne

Le machisme tue tous les jours ${ }^{39}$

La misogynie est une théorie, la violence contre les femmes est sa pratique ${ }^{40}$

Contre la violence sexiste. $4^{41}$

Quand une femme dit non

C'est non ${ }^{42}$

Le féminisme est une théorie extrémiste qui consiste à considérer les femmes comme des êtres

humains $^{43}$

${ }^{38}$ No dia 08 de março de 2009, em Paris, orientanda e orientador da presente pesquisa encontraram etiquetas coladas em cabines telefônicas contendo os dois primeiros dizeres em defesa das mulheres e o último, enquanto uma resposta negativa ao feminismo. A terceira e a quarta frase estavam escritas na calçada da Rue des quatre fils (Rua dos quatro filhos) e na placa que indicava o nome da rua havia uma correção por meio de um papel colado: Rue des quatre filles (Rua das quatro filhas). A quinta manifestação encontrava-se colada em uma placa que sinalizava uma proibição. Ressalta-se que no Brasil tais manifestações também ocorrem.

Pelos direitos das mulheres contra todas as discriminações.

${ }^{39} \mathrm{O}$ feminismo jamais matou ninguém. O machismo mata todos os dias.

${ }^{40}$ A misoginia é uma teoria, a violência contra as mulheres é a sua prática.

${ }^{41}$ Contra a violência sexista!

${ }^{42}$ Quando uma mulher diz não, é não.

${ }^{43} \mathrm{O}$ feminismo é uma teoria extremista que consiste em considerar as mulheres como seres humanos. 
Inicia-se esta seção a partir de uma distinção que Santos (2009) tece a partir da metáfora dos espelhos, a qual ressalta o diferente significado dado a esse objeto por homens (objeto utilitário; distinção da imagem que vêm e aquilo que realmente são) e mulheres (imagem mais visual; maior dependência do objeto; usam-no mais frequentemente para compor sua identidade) e a discriminação sexual que emerge dessa imagem para explicar que a sociedade, assim como os indivíduos, utilizam espelhos e o fazem de uma maneira mais feminina do que masculina. Desse modo, “[...] as sociedades são a imagem que têm de si vistas nos espelhos que constroem para reproduzir as identificações dominantes num dado momento histórico" (SANTOS, 2009, p. 47). Esses espelhos são instituições, normatividades, ideologias que estabelecem correspondências e hierarquias, sendo esses dois últimos elementos que, segundo o autor, colaboram para a criação das identidades. Assim, "A ciência, o direito, a educação, a informação, a religião e a tradição estão entre os mais importantes espelhos das sociedades contemporâneas. O que eles refletem é o que as sociedades são. Por detrás ou para além deles, não há nada" (SANTOS, 2009, p. 48). Os espelhos para a sociedade são processos sociais e podem, conforme seu uso, adquirir vida própria. Nesse contexto, a sociedade

[...] entra numa crise que podemos designar como crise da consciência especular: de um lado, o olhar da sociedade à beira do terror de não ver refletida nenhuma imagem que reconheça como sua; do outro lado, o olhar monumental, tão fixo quanto opaco, do espelho tornado estátua que parece atrair o olhar da sociedade, não para que este veja, mas para que seja vigiado (SANTOS, 2009, p. 48).

$\mathrm{O}$ autor teme que pela importância que adquiriram na sociedade moderna a ciência e do direito tenham se tornado estátuas e, consequentemente, mecanismos de controle.

Ressalta-se que os conceitos que serão trabalhados nessa seção são baseados no Multiculturalismo atual, bem como nas discussões que cercam os Direitos Humanos nesse momento histórico-social. Ressalta-se, ainda, que se buscará trazer para a discussão a cultura do Sul, que tem na mestiçagem de seus povos um traço explícito do Multiculturalismo no Brasil. 


\subsection{Multiculturalismo e Direitos Humanos}

As questões afetas ao Multiculturalismo refletem, em sua essência, uma reflexão ética, na medida em que buscam defender um valor maior: a inclusão, ou seja, o resguardo dos direitos de todos os cidadãos. Mas, o Multiculturalismo puro (tal como desenvolvido na década de 90) não cabe mais no mundo atual, pois os Direitos Humanos devem ser respeitados independentemente das questões multiculturais (p. ex.: sob a égide do respeito ao Multiculturalismo não se pode permitir a extirpação de clitóris de meninas e mulheres ${ }^{44}$ ), mas serão apresentadas algumas pontuações, uma vez que o conceito desse movimento apresenta interessantes propósitos de preservação cultural.

O Multiculturalismo traz, em seu bojo, a questão da diferença ${ }^{45}$, e não da desigualdade, com especial destaque para as questões referentes às minorias (aqui denominadas grupos marginalizados, ou seja, grupos ou comunidades que em uma concepção de senso comum encontram-se à margem da sociedade e sofrem os efeitos negativos dessa localização) relativamente às denominadas maiorias (seu lugar, seus direitos, sua identidade e seu reconhecimento), de onde decorrem os denominados conflitos culturais que, segundo Semprini (1999), podem ser resumidos em três áreas problemáticas: a educação; a identidade sexual e as relações interpessoais; e as reivindicações identitárias em busca de uma maior visibilidade social e cultural e por um acesso mais universalizado ao espaço público.

A ideologia universalista leva as sociedades à "[...] transformar a diferença seja num estado transitório rumo a uma ordem de coisas superior, seja num fato pessoal e privado, além do alcance de suas preocupações. Fundamentada na ideologia da igualdade, a cultura política ocidental enxerga a diferença como uma ameaça [...]” (SEMPRINI, 1999, p. 159). Nesse sentido, a diferença evolui e se modifica a partir do espaço, tempo e contexto em que ela é pensada.

\footnotetext{
${ }^{44}$ No século XIX, as dissertações médicas discutiam o "problema” da masturbação feminina e do tamanho adequado do clitóris (definido naturalmente segundo os critérios desses cientistas), sendo as soluções: ablação, excisão e cauterização, recomendando tesouras ou bisturis para cortá-lo e a melhor posição para fazê-lo, alertando, ainda, para possíveis peritonites, abscessos e morte (NAVARRO-SWAIN, 2004, p. 83-84). Atualmente, no Egito e em outros países do Oriente Médio e África, ainda mutilam-se adolescentes, amputando-lhes o clitóris para reduzir o desejo e prazer sexual. Em nome da tradição e cultura já chegam a 100 milhões as mulheres de 26 países africanos com órgãos sexuais mutilados. A cada ano, mais de 2 milhões de mulheres sofrem mutilações nesses países (TELES, 2007, p. 65).

45 Diferenças são "[...] de natureza biológica ou cultural e não significam a superioridade de algumas pessoas em relação a outras; as desigualdades [, por outro lado,] são fruto da arbitrariedade e das injustiças sociais, criando condições de inferioridade para alguns grupos e classes sociais" (TELES, 2007, p. 23).
} 
Em outras palavras, tem-se que o Multiculturalismo traz, à sociedade, a necessidade do reconhecimento e do respeito pelas diferenças na tentativa de promover a coexistência do respeito aos indivíduos e às comunidades cuja importância é ignorada e, consequentemente, pelo rechaço a atitudes monoculturais de grupos dominantes.

A percepção que um individuo tem de si mesmo e de sua individualidade depende de “[...] estruturas cognitivas, esquemas corporais, afinidades comuns e outras qualificações inscritas num quadro que emerge somente no decurso de interações com os membros de seu grupo de pertença e dos outros grupos sociais” (SEMPRINI, 1999, p. 101), ou seja, a partir de suas interações sociais, inclusive com ambientes informacionais e com seus rótulos de representação do conhecimento construídos. Então, segundo o autor, a igualdade formal e o acesso mais universalizado ao espaço público estão relacionados aos atuais conflitos multiculturais.

As condições de assimilação e depois de integração de uma nova sociedade multicultural, como tradicionalmente ocorre, incluindo-se aqui as unidades e os sistemas de informação, são sempre definidas pela monocultura dominante.

A sociedade multicultural é o contexto onde “[...] os diferentes grupos poderiam ver atendidas suas reivindicações de reconhecimento e identidade, preservando ao mesmo tempo a possibilidade de existência de uma dimensão coletiva - ultrapassando os horizontes da etnia - e de instituições igualitárias e democráticas" (SEMPRINI, 1999, p. 144), ou seja, onde os indivíduos teriam direito à cidadania (que não constitui um território perfeitamente homogêneo), conforme prometido pela democracia.

Uma perspectiva positiva é apresentada por Freire (1996, p. 115) quando ensina que o ser humano "[...] é maior do que os mecanismos que o minimizam."

Tem-se iniciado uma discussão sobre universalismos e totalidades e, conforme alerta Santos (2009, p. 27), o Multiculturalismo “[...] tem florescido nos estudos culturais, configurações transdisciplinares onde convergem as diferentes ciências sociais e os estudos literários e onde se tem produzido conhecimento crítico, feminista, antissexista, antirracista, pós-colonial."

Concorda-se com Santos (2001, p. 16) quando define que o Multiculturalismo "[...] é precondição de uma relação equilibrada e mutuamente potenciadora entre a competência global e a legitimidade local, que constituem os dois atributos de uma política contrahegemônica de direitos humanos no nosso tempo."

Os Direitos Humanos trazem, em seu bojo, “[...] três qualidades encadeadas: devem ser naturais (inerentes nos seres humanos), iguais (os mesmos para todo mundo) e universais 
(aplicáveis por toda parte)" (HUNT, 2009, p. 19). Para que essas qualidades fossem aplicáveis todos os indivíduos as possuiriam apenas pelo requisito básico de serem seres humanos, mas esses direitos são significativos apenas a partir do momento que agregam um conteúdo político, ou seja, quando são inseridos em uma sociedade. Mas, além disso, o conceito natural, igualdade e universalidade só poderiam ser considerados em sua essência se todos os seres humanos fossem semelhantes.

Hunt (2009) apresenta aspectos historiográficos que permearam a criação dos Direitos Humanos e para isso utiliza três documentos importantes, sendo eles: Declaração da Independência (Estados Unidos da América, 1776), Declaração dos Direitos do Homem e do Cidadão (França, 1789) e Declaração Universal dos Direitos Humanos (Nações Unidas, 1948).

Assim, como ocorre com os valores morais discutidos na seção anterior, tem-se certeza de que um direito humano está em questão quando este é desrespeitado e automaticamente sente-se uma repulsa, um horror a essa violação.

A revolução dos Direitos Humanos será contínua, mas partiu de “[...] novos tipos de leitura (e de visão e audição) [que] criaram novas experiências individuais (empatia), que por sua vez tornaram possíveis novos conceitos sociais e políticos (os direitos humanos)" (HUNT, 2009, p. 32). Então, para que esses direitos se tornassem autoevidentes, pessoas comuns passaram por novas experiências que mostraram a individualidade inerente a cada um.

Dessa maneira, a autora destaca alguns fatores que estimularam essa mudança de perspectiva, ou seja: a conscientização sobre a tortura e a legalidade com que a mesma era empregada; a leitura de romances, principalmente o repistolar, a partir da qual houve uma identificação com os personagens que exercitavam sua individualidade e ressaltavam a capacidade que existe em cada pessoa; a proliferação de pinturas de retratos; a valorização da individualidade dos corpos e a repulsa pela sua violação (o que rendeu um valor mais positivo aos corpos durante o século XVIII); a mudança da concepção de honra; a abolição da escravidão (a qual, segundo a autora, não seria concebível em 1794 sem a declaração inicial); as discussões sobre os Direitos Humanos em contraposição a estrutura hierárquica da sociedade; as explicações sobre as diferenças (principalmente as explicações biológicas que emergiram no século XVIII); o surgimento das organizações não-governamentais (ONGs) que começaram a pressionar o governo; entre outros.

A inserção desses e de outros fatores na discussão dos Direitos Humanos aconteceu lentamente e sua concretização também. A ligação entre os Direitos Humanos e a tortura e o castigo cruel utilizados como punição e como forma de extrair informações, por exemplo, 
demorou a ser feita inclusive pela elite educada e por alguns reformadores, como explica Hunt (2009), pois esses cidadãos não viam a tortura e o castigo cruel como desrespeitando os Direitos Humanos quando usados para fins de julgamento e punição.

Conforme esses sentimentos e concepções foram se inserindo na vida social, alguns comportamentos tiveram que se modificar, como os hábitos de educação e higiene, por exemplo.

Quando se adentram discussões sobre os Direitos Humanos não há como não considerar as lutas de gênero, pois este "[...] interfere na formulação e na implementação da legislação, dos conceitos da normatização, de direitos, de justiça” (TELES, 2007, p. 60).

As mulheres, enquanto dependentes de seus pais e maridos (patriarcado) não eram vistas como capazes de ter autonomia moral, isto é, não adquiririam ao longo da vida os Direitos Humanos, como ocorria ou poderia ocorrer com as crianças do sexo masculino, os criados, os sem-propriedade e, inclusive, os escravos.

A honra e a virtude das mulheres, esclarece Hunt (2009), era privada e doméstica, enquanto a dos homens era pública, desse modo, mesmo que fossem julgadas e punidas por algum delito, as mulheres não tinham direitos políticos a perder, como acontecia com os homens. As mulheres, “[...] nunca ganharam direitos políticos iguais durante a Revolução. Elas ganharam, entretanto, direitos iguais de herança e o direito ao divórcio" (HUNT, 2009, p. 150).

As discussões sobre os direitos das mulheres "[...] veio à tona periodicamente na Europa durante os séculos XVII e XVIII, sobretudo com respeito à educação das mulheres, ou à falta dessa educação [...]" (HUNT, 2009, p. 169). Em contrapartida, seus direitos sociais e políticos não foram exigidos por meio de guerras, panfletos, competições públicas de publicações, comissões do governo ou organizações durante as Revoluções Francesa ou Americana, como aconteceu com os protestantes franceses, com os judeus e com os escravos. Hunt (2009) explica que, talvez, isso tenha se dados pelo fato de as mulheres não constituírem uma minoria perseguida, além do que ninguém estava forçando-as a mudar de identidade.

Essas discussões sobre os direitos das mulheres ocorreram na França e na Inglaterra por volta de 1790 e nos Estados Unidos por volta de 1792 (HUNT, 2009).

A partir dos aspectos apresentados por Teles (2007) pode-se dizer que a violação dos Direitos Humanos não se dá apenas em espaços e por agentes públicos, mas, também, em espaços e agentes privados, como o lar e o cônjuge, por exemplo. Atualmente, o Estado é responsável pela violação dos Direitos Humanos e têm nas medidas de segurança pública e no estabelecimento de políticas públicas instrumentos para intimidar essas violações. 
Os Direitos Humanos são universais, inalienáveis, indivisíveis e interdependentes. Mas, esse caráter natural e autoevidente que se instalou no âmago desses conceitos estimulam o surgimento e a proliferação de ideologias da diferença, nem sempre sadias.

Após o estabelecimento e divulgação da Declaração Universal dos Direitos Humanos (1948) houve, e talvez ainda há, uma falsa ilusão de finalização da questão, mas a sua essência nunca poderá parar de ser discutida uma vez que o mundo tal como está hoje, abriga muitas culturas e suas especificidades têm de ser consideradas. Assim, teria que haver uma combinação entre as diretrizes fornecidas pelas declarações e a inclusão das especificidades culturais.

Santos (2001) realiza essa discussão e comenta que essa política dos Direitos Humanos é ao mesmo tempo reguladora e emancipadora e retoma que:

[...] enquanto a primeira geração de direitos humanos (os direitos civis e políticos) foi concebida como uma luta da sociedade civil contra o Estado, considerado como principal violador potencial dos direitos humanos, a segunda e a terceira gerações (direitos econômicos e sociais e direitos culturais, da qualidade de vida etc.) pressupõem que o Estado [Estado-nação e globalização] é o principal garante dos direitos humanos (SANTOS, 2001, p. 8-9).

Nesse contexto, tem-se uma falsa ideia de homogeneização, isto é, quando algo se insere em uma dimensão global, se esquece que uma dimensão local também está inserida nele. O autor diferencia o localismo globalizado (elementos dos países dominantes são inseridos em determinado local) e o globalismo localizado (impacto das práticas e imperativos transnacionais nas condições locais), assim “[...] enquanto forem concebidos como direitos humanos universais, os direitos humanos tenderão a operar como localismo globalizado - uma forma de globalização de-cima-para-baixo" (SANTOS, 2001, p. 15). Uma solução apresentada pelo autor seria reconceitualizar os Direitos Humanos como sendo multiculturais.

Santos (2001) salienta que atualmente há quatro regimes internacionais de aplicações dos Direitos Humanos: o europeu, o interamericano, o africano e o asiático e que "Todas as culturas tendem a considerar os seus valores máximos como os mais abrangentes, mas apenas a cultura ocidental tende a formulá-los como universais" (SANTOS, 2001, p. 16).

Essa discussão não pode ocorrer em um ambiente competitivo entre culturas diferentes defendendo seus valores máximos sobre o que é e o que compõe a dignidade humana, 
destacando que em algumas culturas compor a dignidade humana não garante que determinada premissa adentre os Direitos Humanos.

Uma possível solução seria

[...] um diálogo intercultural sobre a dignidade humana que pode levar, eventualmente, a uma concepção mestiça de direitos humanos, uma concepção que, em vez de recorrer a falsos universalismos, se organiza como uma constelação de sentidos locais, mutuamente inteligíveis, e se constitui em redes de referências normativas capacitantes (SANTOS, 2001, p. 20).

Esse diálogo deve ser permeado por dois imperativos interculturais aceitos pelos grupos participantes.

O primeiro imperativo é enunciado da seguinte maneira: “[...] das diferentes versões de uma dada cultura, deve ser escolhida aquela que representa o círculo mais amplo de reciprocidade dentro dessa cultura, a versão que vai mais longe no reconhecimento do outro" (SANTOS, 2001, p. 28).

O segundo imperativo é enunciado da seguinte maneira:

uma vez que todas as culturas tendem a distribuir pessoas e grupos de acordo com dois princípios concorrentes de pertença hierárquica, e, portanto, com concepções concorrentes de igualdade e diferença, as pessoas e os grupos sociais têm o direito de ser iguais quando a diferença os inferioriza, e o direito de ser diferentes quando a igualdade os descaracteriza (SANTOS, 2001, p. 28).

No contexto da representação do conhecimento, dois pontos devem ser negociados: amparar as especificidades culturais de comunidades discursivas não negando a necessária “compatibilidade universal" visando à comunicação científica.

\subsection{A questão feminina}

A discussão entrará a partir desse momento nos aspectos que permeiam o preconceito e a discriminação em relação às mulheres, para tanto se ressalta a seguinte constatação de Santos (2009, p. 87): "O binômio cultura/ natureza pertencente a uma longa família de dualismos em que podemos distinguir, entre outros, abstrato/ concreto, espírito/ corpo, sujeito/ objeto, ideal/ real." O autor salienta o sexismo inerente a esses dualismos uma vez que o 
primeiro polo é sempre considerado dominante e da mesma maneira masculino. Mas, esses dualismos estão tão intrínsecos a educação e aos comportamentos e manifestações científicas e sociais que passam, muitas vezes, desapercebidos.

Auad (2003, p. 87) recorda que "A opressão contra as mulheres aparece de diferentes formas em todas as classes e camadas sociais, em diferentes grupos étnicos e culturais.”

Em resposta a isso, as feministas estão certas de que o feminismo é um movimento político e social, bem como de que existem feministas e feminismos, mas o movimento como um todo, segundo Auad (2003, p. 87-88):

1. questiona as relações de poder, a opressão e a exploração de grupos de pessoas uns sobre os outros;

2. contrapõe-se radicalmente às relações estabelecidas em nossa sociedade entre o masculino e o feminino, isto é, às relações de gênero vigentes;

3. propõe uma transformação social, econômica, política e ideológica da sociedade.

Os movimentos feministas apresentam algumas mudanças em seus objetos de luta ao longo do tempo, o que alguns autores denominam como sendo ondas do feminismo, mas destaca-se apenas que durante suas trajetórias os feminismos buscaram primeiramente uma igualdade entre os sexos com objetivos jurídico-legais, civis e sufragistas; em seguida, são inseridas as discussões de gênero $^{46}$ (Exemplos dessa fase são os filmes: Cartas a uma $\operatorname{ditadura}^{47}$; e $\mathrm{O}$ sorriso de Mona $\mathrm{Lisa}^{48}$ ); um outro momento surge, enquanto debate pósmoderno, ou seja, movimentos feministas com o objetivo de inserção da mulher sem a exclusão do homem, passando-se de um feminismo essencialista para um feminismo diferencialista (a igualdade para afirmar as diferenças). Essa última passagem exigirá dos homens uma mudança de postura, uma vez que eles serão, assim como as mulheres, portadores de direitos e deveres, mas não mais portadores de privilégios.

\footnotetext{
${ }^{46} \mathrm{O}$ termo gênero "[...] deve ser empregado para explicitar uma ordem social e institucional que impulsiona a construção sociocultural de ser mulher e de ser homem, o que tem determinado desigualdades históricas entre os sexos. A construção institucional se dá em níveis econômico, social, político e cultural" (TELES, 2007, p. 50). Segundo Aguilar García (2008, tradução nossa), gênero é uma categoria de análise social e não deve ser confundido com o termo mulher. Algumas autoras sugerem a inclusão de termos intermediários entre sexogênero de maneira a evitar o reducionismo dessa relação e incluem distinções como "[...] corporização sexuada, sexualidade, identidade de gênero, papel de gênero, simbolismo de gênero etc." Ver definições denotativas do termo gênero nas páginas 74-75.

${ }^{47}$ CARTAS a uma ditadura. Produção de Inês de Medeiros. Portugal: Faux Edições e Audiovisuais Ltda., 2006. 1 DVD.

${ }^{48}$ MONA Lisa Smile. Produção de Elaine Goldsmith-Thomas, Deborah Schindler e Paul Schiff. Estados Unidos: Columbia Pictures, 2003. 1 DVD.
} 
O essencialismo retoma a discussão das negativas concepções relacionadas às mulheres ao longo do tempo, considerando-as genéricas (ou seja, enquanto as mulheres eram rotuladas como mulheres sem mais, os homens eram rotulados a partir de sua família, profissão, cargo, enfim eram rotulados a partir das imagens construídas acerca deles) e associando-as a variáveis de submissão e fragilidade. O pensamento misógino, ou seja, o desprezo em relação às mulheres, apresenta, na maioria das vezes,

[...] uma autojustificativa conveniente para a posição secundária das mulheres ao contê-las no interior de corpos que são representados, até construídos, como frágeis, imperfeitos, desregrados, não confiáveis, sujeitos a várias intrusões que estão fora do controle consciente. A sexualidade feminina e os poderes de reprodução das mulheres são as características (culturais) definidoras das mulheres e, ao mesmo tempo, essas mesmas funções tornam a mulher vulnerável, necessitando de proteção ou de tratamento especial, conforme foi variadamente prescrito pelo patriarcado. A oposição macho/ fêmea tem sido intimamente aliada à oposição mente/ corpo (GROSZ, 2000, p. $67^{49}$ citado por AZERÊDO, 2007, p. 23).

Aguilar García (2008) apresenta profícua revisão teórica sobre o feminismo. Partindo das origens do sistema sexo-gênero, o artigo caracteriza o feminismo francês da diferença, o feminismo radical e o movimento Queer dos anos 90, bem como as principais teorias e teóricas que constroem esse domínio do conhecimento e representam essa comunidade discursiva.

O campo teórico relativo aos estudos de gênero, conforme esclarece Teles (2007), despontou juntamente com outros movimentos sociais que eclodiram na década de 1980 buscando identidade, tais como: negras, lésbicas, gays, travestis, transexuais, portadoras do vírus HIV/ Aids, presidiárias, portadoras de necessidades especiais, idosas, imigrantes, indígenas etc.

Assim, a essa reflexão são inseridas outras variáveis, ou seja, tem-se que refletir a questão feminina a partir da classe social, cultura, etnia, geração, opção sexual, raça e religião.

Por exemplo, "A figura da Amélia introduz a necessidade de se considerar a categoria classe social para pensarmos o preconceito contra a mulher, e, por sua vez, a figura da mulata e da mulher negra [...]" (AZERÊDO, 2007, p. 21).

Outro exemplo é explicado por Navarro-Swain (2004), ou seja, a heterossexualidade compulsória e a naturalização dos papéis femininos e masculinos além se assegurar uma

\footnotetext{
${ }^{49}$ GROSZ, E. Corpos reconfigurados. Cadernos Pagu, Campinas, v. 14, p. 45-86, 1994.
} 
dominação hierárquica tida como natural, reafirma o patriarcado e coloca as relações homossexuais entre as mulheres como um perigo que acarretaria a perda do poder masculino.

No século XIX, para encontrar aspectos relacionados à homossexualidade feminina em certos tratados era preciso buscar "[...] entre os canibais, os zoófilos, necrófilos, coprófagos, estupradores, assassinos passionais, manifestações estas classificadas em conjunto como 'psicopatologia sexual'” (NAVARRO-SWAIN, 2004, p. 55) ${ }^{50}$. A essência dessa percepção foi mantida durante muito tempo e, somente a partir de lutas dos movimentos feministas e dos Direitos Humanos, é que se começou a ver ações mais concretas para a dissolução desse rótulo imposto por valores morais e religiosos de um grupo dominante.

Em relação as homossexuais femininas, ou seja, as lésbicas ou lesbianas, não se deve estabelecer padrões ou identidades fixas, pois isso seria rotular uma verdadeira lésbica, tal como se faz com as verdadeiras mulheres, conforme sinaliza Navarro-Swain (2004).

Apesar de todas essas variáveis expostas, o preconceito contra a mulher continua se cristalizando e naturalizando de maneira que inclusive as mulheres acabam perpetuando-o. $\mathrm{O}$ processo de produção do preconceito se dá no decorrer de todas a nossa existência, pois já nascemos em um mundo com discursos, significados e sentidos (isto é, significados em um dado contexto).

O preconceito gera violência. A naturalização e impunidade da violência contra as mulheres vêm sendo discutidas e amparadas juridicamente e em declarações, conferências, instituições, trabalhos acadêmicos, ações afirmativas etc.

A violência contra os Direitos Humanos das mulheres ocorre, como demonstra Teles (2007): a partir da morte materna; a partir do tráfico sexual; ausência das mulheres indígenas (seja em políticas públicas, seja em discussões teóricas); ausência de representação feminina na política; conjugal; de gênero (também denominada violência sexista); doméstica (também denominada violência familiar ou na família); em relação as migrantes; na área policial ou judiciária; na educação (ao reforçar estereótipos sexistas, por exemplo); nas guerras (abuso moral e sexual das mulheres capturadas em guerras); no trabalho (por meio do estupro; menores salários; dificuldade de acesso ao mercado; são as primeiras a serem demitidas mediante cortes etc.); nos presídios; nos serviços de saúde (realizar o procedimento de curetagem sem anestesia, por exemplo); patrimonial; psicológica; sexual; a partir de agressões verbais ou físicas ou ambas.

\footnotetext{
50 “Ao nomear, identificar, rotular as lesbianas enquanto bias da natureza, caricatura do masculino ou certa patologia, as ciências e o senso comum criaram, ao mesmo tempo, o espaço de sua existência, de sua presença no mundo" (NAVARRO-SWAIN, 2004, p. 63), permitindo a identificação e união de indivíduos com as mesmas necessidades de conhecimento, possibilitando muitas saídas do armário (out of the closet, em inglês).
} 
Essa violência tem um aspecto natural perante a maior parte das sociedades, as quais encontram desculpas para que elas ocorram, muitas vezes culpando a própria vítima pela agressão sofrida, ou culpando fatores que são sim agravantes, mas nunca determinantes, tais como: o alcoolismo, a pobreza, a falta de instrução, entre outros.

Assim, “[...] a teoria e a prática feministas se desenvolveram através da produção de uma linguagem nova que desconstrói as definições e os conceitos que nos prendem a uma subjetividade sujeitada" (AZERÊDO, 2007, p. 109).

Nesse contexto, o diferencialismo ressurge acompanhando a nova realidade das mulheres. Atualmente, as mulheres chefiam famílias sem a infraestrutura necessária do Estado; competem, mesmo com os preconceitos muitas vezes presentes, pela inserção no mercado de trabalho; utilizam tecnologias para o controle e redução de fertilidade; e são diferentes entre si (TELES, 2007).

A necessária mudança do sentido da palavra mulher "[...] tem se dado de forma lenta e se dá sempre por meio de relações de poder, da desigualdade dos poderes, de suas lutas" (AZERÊDO, 2007, p. 30), sendo assim esse conceito mudará apenas quando as próprias mulheres refletirem sobre ele, adaptarem-no a sua realidade e defendê-lo, ou seja, responsabilizarem-se por ele, pois o conceito mulher não deve, de maneira alguma, ser considerado universal e estático.

Antes de iniciar a discussão da máxima que as mulheres figuram um domínio delicado no tocante a representação do conhecimento, mais especificamente nas linguagens documentais, uma vez que questões científicas são mescladas com especificidades históricas, sociais e culturais, far-se-á uma exposição sobre a situação feminina na ciência, a partir da reflexão estatisticamente fundamentada de Schiebinger (2001).

A ciência e suas instituições (assim como a sociedade e suas ideologias) não são de gênero neutras, pois valores atribuídos às mulheres foram excluídos de seus contextos (a empatia é tida como uma maneira de conhecer específica das mulheres, por exemplo), enquanto desigualdades de gênero foram construídas na produção e estruturação do conhecimento. Desse modo, para que as mulheres tornem-se iguais na ciência, seriam “[...] necessárias mudanças, não apenas nas mulheres, mas também nas aulas de ciências, nos currículos, laboratórios, teorias, prioridades e programas de pesquisa" (SCHIEBINGER, 2001, p. 24).

Há críticas em relação à maneira "das mulheres" fazerem ciência e aos métodos supostamente femininos que empregam, mas: 
É tempo de afastar-se de concepções de ciência feminista como empática, não-dominadora, ambientalista, ou "favorável às pessoas". É tempo de voltar-se, ao invés disso, para instrumentos de análise pelos quais a pesquisa científica possa ser desenvolvida, bem como criticada em linhas feministas (SCHIEBINGER, 2001, p. 31).

A exclusão das mulheres da ciência causa prejuízos tanto para as próprias quanto para a ciência e o conhecimento produzido, mas a autora salienta que essa formalização rigorosa e excludente ocorreu na ciência a partir do fim do século XVII com seus arranjos informais desfeitos e início do século XIX com suas institucionalização e com a profissionalização da ciência, pois anteriormente as mulheres tinham mais acesso e participação. Dois problemas com raízes históricas profundas são ainda muito utilizados nessa discussão, sendo eles: a oposição responsabilidades domésticas $\mathrm{X}$ responsabilidades profissionais e relógio da carreira acadêmica X relógio biológico, conforme ressalta Schiebinger (2001).

Destacam-se, dessa maneira, "Dois desenvolvimentos básicos na ciência e na sociedade europeia - a privatização da família e a profissionalização da ciência - [os quais] foram cruciais para na estruturação desse histórico choque de culturas" (SCHIEBINGER, 2001, p. 141).

A obra da autora faz uma completa reflexão envolvendo profissões, produção científica, ciência (matemática, física, química, biologia e engenharias; poucas pontuações foram feitas sobre as denominadas humanidades e ciências sociais), formação escolar e acadêmica, educação infantil, estereótipos, comportamentos e brinquedos e conclui que as mudanças que ocorreram até hoje não se deram de maneira "natural", mas são resposta às condições sociais e climas de opinião.

Interesses políticos, bem como políticas de financiamento influenciam a produção de conhecimento, mas fatores como instrumentos de análise de gênero deveriam também influenciar essa produção, pois além de evidenciar a posição da mulher na comunidade científica (p. ex.: a obtenção de igualdade sexual numa conferência por meio do mesmo número de palestrantes de ambos os sexos), responderia como o gênero influencia o conteúdo da ciência (p. ex.: estruturação de uma amostra representativa de animais ou humanos para um experimento específico ou um conjunto de observações; a reflexão sobre o fato de que a escolha de objetos de estudo pode ter implicações além daquelas relacionadas diretamente a fêmeas e machos).

Assim, não basta que universidades recrutem mulheres por meio de iniciativas e políticas públicas (mesmo porque isso acontece apenas quando há verba disponível), pois são necessários “[...] programas projetados para mudar as culturas internas dos departamentos de 
ciência [...]” (SCHIEBINGER, 2001, p. 347). Algumas instituições apoiam reformas de currículo, mas ainda não estruturam mecanismos para detectar biasses na pesquisa.

\subsection{A questão feminina na representação do conhecimento}

No tocante a representação do conhecimento, o conceito, isto é, a significação surge a partir da diferença ambientada em um plano comum, mas esses elementos são vistos pela sociedade como a desigualdade em uma cultura. Essa significação ocorre a partir da língua que atua como "[...] palco privilegiado da luta de classes, expressão e registro dos valores e sentimentos contraditórios de exploradores e explorados" (CARBONI; MAESTRI, 2003, p. $10)$.

A língua, desse modo,

[...] não é função do sujeito falante nem sucessão de palavras correspondentes a outras equivalentes. É um sistema-estrutura de valores e formas. Os sistemas de valores não são construções particulares de um indivíduo; são, antes, o resultado de todo um contexto sócio-histórico que determina as condições de produção do discurso (CINTRA et al., 2002, p. $31)$.

Por exemplo, no dicionário, gênero consiste em:

[Do lat. genus, eris, 'classe', 'espécie', poss. pelo pl. lat. genera, ou pelo lat. *generum, com mud. de declinação]. S. m. 1. Lóg. Classe cuja extensão se divide em outras classes, as quais, em relação à primeira, são chamadas espécies. 2. Lóg. Um dos predicáveis: característica(s) que uma coisa tem em comum com outra, e que lhe(s) determina(m) a essência, quando acrescida da diferença [Cf., nesta acepç., classe]. 3. P. ext. Qualquer agrupamento de indivíduos, objetos, fatos, ideias, que tenham caracteres comuns; espécie, classe, casta, variedade, ordem, qualidade, tipo. 4. Maneira, modo, estilo. 5. Nas obras de um artista, de uma escola, cada uma das categorias que, por tradição, se definem e classificam segundo o estilo, a natureza ou a técnica. 6. Classe ou natureza do assunto abordado por um artista. 7. Antrop. A forma culturalmente elaborada que a diferença sexual toma em cada sociedade, e que se manifesta nos papéis e status atribuídos a cada sexo e constitutivos da identidade sexual dos indivíduos. 8. Biol. Categoria taxonômica compreendida entre a família e a espécie. 9. E. Ling. Categoria gramatical que dispõe os nomes de uma língua em classes (como feminino, masculino, neutro, animado, inanimado) de acordo com: (a) a referência pronominal (a casa/ ela; o menino/ ele); (b) a concordância com os modificadores (a menina bonita/ o gato gordo); (c) a presença de determinados afixos (como, 
p. ex., -triz). 10. Geom. Anal. Diferença entre o número máximo de pontos duplos que uma curva unicursal pode ter e o número dos que ela realmente possui; deficiência. 11. Geom. Anal. Metade do número de cortes que devem ser feitos em uma superfície para que ela se torne simplesmente conexa. $\sim \mathrm{V}$. gêneros. Gênero de vida. Conjunto de atividades habituais, provenientes da tradição, mercê das quais o homem assegura a sua existência, adaptando a natureza em seu proveito. Gênero humano. A espécie humana; a humanidade. Comum de dois gêneros. E. Ling. V. comum-de-dois. Fazer gênero. Bras. Gír. Fingir ser o que não é. Não fazer o gênero de. Bras. Não estar conforme a opinião ou gosto de (alguém); não agradar a. (FERREIRA, 1999, p. 980).

Para a presente pesquisa, duas das definições apresentadas acima são imprescindíveis, sendo elas: a) a número 7, que o dicionário optou por inserir em Antropologia e que abarca todas a discussão apresentada aqui sobre a mulher; e b) a número 9, enquanto categoria gramatical e que também abarca a discussão apresentada, uma vez que se está tratando sobre linguagem documental, ou seja, um léxico.

Quando se pensa na presente pesquisa a partir dessas duas definições, compreende-se a sua real complexidade, pois consiste em uma discussão antropológica e conceitual, ou seja, mutável e com muitas variáveis, que perpassa obrigatoriamente uma categoria gramatical, ou seja, mais estática do que mutável e normativa.

Por esse motivo, a linguagem documental necessita de uma dinâmica que a adeque ao momento histórico-social, mas em alguns casos, os preconceitos estão implícitos na própria linguagem natural e isso não será facilmente modificado. Mas, por outro lado, quando se fala em linguagens documentais há como se criar mecanismos que se não excluem ao menos sinalizam potenciais preconceitos.

No contexto específico da OC, destacam-se alguns estudos aplicados relacionados às questões de gênero e suas possíveis biasses, sendo eles: perspectivas de gênero e discriminação de "minorias" na CDU (SANTOS; MADINA; SERRA, 1999); como a mulher se encontra representada e nomeada na CDU (MORÁN SUÁREZ; RODRIGUÉZ BRAVO, 2001); a ORC de gênero na Internet (LÓPEZ-HUERTAS; BARITÉ ROQUETA, 2002); a análise da representação terminológica em quatro tesauros direcionados às questões da mulher - Europa, Espanha, Itália e Brasil (LÓPEZ-HUERTAS; TORRES; BARITÉ, 2004); a comparação entre como duas culturas diferentes, Espanha e Uruguai, podem influenciar o desenvolvimento de um campo de conteúdo como os Gender Studies, e como isso pode afetar a OC em SORC (LÓPEZ-HUERTAS, 2008a); e a questão da mulher nas linguagens documentais: listas de cabeçalhos de assunto (Lista de encabezamientos de materia para las bibliotecas públicas; Lista de encabezamientos de materia de la Red de bibliotecas del 
Consejo Superior de Investigaciones Científicas; e Encabezamientos de materia de la biblioteca universitária, Universidad de Sevilla) e tesauros (Tesauro de la Unesco; Tesauro ISOC de Psicologia; Thesaurus d'història de la dona; Tesauro "Mujer") (RODRIGUÉZ BRAVO, 2007).

Os referidos estudos salientam e exemplificam discriminações de gênero e constatam que "[...] há a necessidade de um modelo de organização do conhecimento ideal para cada domínio" (LÓPEZ-HUERTAS; TORRES; BARITÉ, 2004, p. 38, tradução nossa).

Outro problema constatado pelos autores é a não-uniformidade da representação do conteúdo documental e a ênfase na representação de aspectos de gênero ligados apenas à sexualidade (especialmente com a homossexualidade), vida familiar ou relacionamentos pessoais.

A partir dos estudos de Rodríguez Bravo (2006) em relação a LSCH, o Thesaurus UNESCO e o European Women's Thesaurus, destaca-se que no tocante a LCSH os cabeçalhos refletem as tradicionais discriminações sociais em relação à mulher, enfatizando aspectos como situação conjugal, sexualidade e procedimentos relacionados à maternidade.

Assim, no tocante às linguagens documentais, seria recomendável incluir as comunidades discursivas marginalizadas “[...] segundo sua condição étnica, linguística, política, religiosa, nacional, ideológica, social, econômica [...]" (CARO CASTRO; SAN SEGUNDO MANUEL, 1999, p. 105, tradução nossa). As autoras citam ainda a falta de atualização, adequação e concretização dos critérios de elaboração, ou seja, a falta de políticas de gestão.

Nas linguagens documentais tradicionais,

a presença feminina é escassa porque a linguagem institui o masculino como universal, como genérico [buscando, talvez, uma economia de linguagem], e, também, inapropriada porque seu discurso de representação do conhecimento mantém os estereótipos femininos, oferecendo uma imagem anacrônica da mulher e apresenta mostras de sexismo (RODRÍGUEZ BRAVO, 2007, tradução nossa).

Especificamente nas questões de gênero, Olson (2002, p. 9, tradução nossa) constata que em questões que envolvem a representação da mulher e para a mulher as padronizações têm três problemas comuns:

- Tratam as mulheres como exceções as normas masculinas;

- Isolam as questões da mulher para separá-las do resto do conhecimento; ou

- $\quad$ Omitem essas questões inteiramente. 
López-Huertas Pérez e Torres Ramírez (2005) salientam mais concretamente essas biasses, ou seja:

- Considerar generalidade como masculinidade;

- Considerar que o sujeito da anticoncepção é a mulher;

- Termos masculinos usados no plural com o conteúdo semântico de homens e mulheres;

- Expressão formada por substantivo + adjetivo, observa-se a tendência de se criar descritores femininos e omitir seus correspondentes masculinos.

Lembrando que mesmo que sejam historicamente e gramaticalmente construídos, esses termos e estruturas geram prejuízos a determinadas comunidades discursivas no tocante ao acesso e recuperação da informação, sendo assim os mecanismos disponibilizados pela Documentação para as linguagens documentais, explicados na seção anterior e retomados na seção 7, podem oferecer elementos para uma maior democratização das mesmas.

Destaca-se que se elegeram as constatações de Olson (2002) e López-Huertas Pérez e Torres Ramírez (2005) apresentadas acima para compor a grade principal de análise dos dados da presente pesquisa.

Tais problemas morais são salientados por Vieira Júnior (2005, p. 11) e, também, pela sociedade, que para garantir a "normalidade" de seus cidadãos utiliza como base alguns mecanismos de controle, tais como: o Estado; a Igreja; a Família; a Escola; a Biblioteca; e os Meios de Comunicação (salientados também por Santos (2009) a partir dos exemplos dos espelhos na página 62).

Comumente, todos os conteúdos documentais referentes às mulheres são rotulados a partir da entrada Mulheres. Nos tesauros produz-se "[...] uma maior simetria no tratamento do feminino e do masculino. As listas de cabeçalhos reservam à mulher um espaço específico e apresentam um abundante número de cabeçalhos para permitir representar a temática feminina oculta no grosso do vocabulário da lista” (RODRÍGUEZ BRAVO, 2007).

Têm-se, então, muitos vazios terminológicos motivados, muitas vezes, por vazios culturais no caso de traduções e versões. Assim, "O grau de precisão da terminologia pode chegar a ser um fiel indicador do nível de desenvolvimento dessa temática em diversas culturas" (LÓPEZ-HUERTAS PÉREZ; TORRES RAMÍREZ, 2005, tradução nossa).

Ao desenvolver uma linguagem documental para amparar os estudos das mulheres, deve-se refletir sobre como representar o masculino. López-Huertas Pérez e Torres Ramírez (2005, tradução nossa), afirmam que "É uma questão importante porque a forma de fazê-lo pode estar marcada por uma ideologia que incida negativamente sobre a objetividade 
desejável." Há uma tendência lógica que orienta a se evitar descritores que incluam os termos Mulher e Mulheres como elemento nuclear.

Considerando que as atitudes sociais devem ser modificadas em respeito aos marginalizados, estigmatizados e excluídos, destaca-se a linguagem documental enquanto um excelente meio para se aplicar essa reflexão.

Para tanto, possíveis auxílios são apresentados por Rodríguez Bravo (2007), sendo eles:

- $\quad$ Inserção da mulher sem que ocorra a ocultação do masculino, ou seja, esforços em busca da "[...] eliminação de estereótipos sexistas das linguagens documentais, busca do equilíbrio entre a presença do homem e da mulher e eliminação de masculinos como falsos genéricos" (RODRÍGUEZ BRAVO, 2007, tradução nossa).

- Inserção de notas que autorizem a utilização do feminino e/ ou o emprego de cabeçalhos/ descritores sintagmáticos para distinguir o masculino do genérico quando não houver outra opção;

- Inserção de qualificadores de gênero junto aos cabeçalhos/ descritores, sendo eles "(M)" e "(H)", quando a temática não representar a humanidade em geral.

A partir da próxima seção, a pesquisa continua caminhando em busca de soluções, pois

[...] estudos críticos e epistemológicos de domínios do conhecimento fornecem conhecimento sobre os fundamentos dos domínios e avaliações críticas de suas declarações de conhecimento. Eles fornecem diretrizes para seleção, organização e recuperação da informação e fornecem o mais alto nível de generalidade sobre necessidades informacionais e critérios de relevância que podem ser obtidos (HJØRLAND, 2002, p. 440, tradução nossa).

Ressalta-se que as pontuações e considerações das próximas seções representam uma primeira tentativa e se encontrarão permanentemente abertas em busca de sinalizações e discussões acerca das biasses no tocante a mulher nas linguagens documentais brasileiras. 


\section{MATERIAL E MÉTODOS}

De modo a fornecer embasamento aplicado à teoria apresentada, a presente pesquisa qualitativa, exploratória e documental, de caráter descritivo, pois dados serão coletados minuciosamente em forma de palavras, e indutivo, na medida em que a análise dos dados busca a teoria fundamentada, contribuirá com a área por meio de subsídios e reflexões.

\subsection{Procedimentos de pesquisa}

Para a identificação dos termos referentes à questão feminina, foi utilizado um domínio conceitual composto pelos termos: feminilidade; feminina(s); feminino(s); feminismo(s); feminista(s); materna(o); maternal; mulher(es); bem como seus respectivos termos em inglês: female; femininity; feminism; feminist; maternal; motherly; woman(en). $\mathrm{O}$ domínio estabelecido procurou englobar a mulher, a teoria feminista e a situação feminina e foi objeto de busca nas seguintes linguagens documentais brasileiras: VCB, VCUSP, TAFBN e CDDireito.

Ressalta-se que, no projeto original dessa pesquisa, além das linguagens documentais alfabéticas brasileiras, havia sido proposta a análise das linguagens documentais internacionais LCSH e CDD, o que não ocorreu por dois motivos, sendo eles: 1) no decorrer da coleta de dados na linguagem documental brasileira TAFBN constatou-se que sendo esta uma versão da LCSH que sinaliza os termos que foram acrescentados ou modificados do original, permitiu que fossem obtidos subsídios iniciais de como a questão feminina é tratada na própria $\mathrm{LCSH}$; e, no tocante a CDD, decidiu-se não analisá-la a partir dessa metodologia nesse momento, devido a grande quantidade de dados que seria gerada a mais, tornando difícil garantir a qualidade da análise e discussão dos mesmos. Além disso, os estudos de Olson (1998, 2002) e Rodríguez Bravo (2006) mantêm-se atuais em relação a essa temática.

Ressalta-se, também, que a CDDireito foi acrescentada ao corpus de modo a representar a categoria de linguagem documental hierárquica na realidade brasileira.

Relativamente às linguagens documentais alfabéticas: VCB, VCUSP, TAFBN, cada termo identificado gerou uma ficha de registro, onde foram registrados seu descritor, nota de 
escopo, relação de equivalência (UP/ USE), relação associativa (TR) e relação hierárquica (TG/ TE), conforme demonstra o exemplo ao final desta subseção.

Já para a análise da linguagem documental hierárquica, a ficha de registro foi preenchida respondendo às seguintes categorias, baseadas em Olson (1998): notação, conceito classificatório, contexto hierárquico e nota, conforme se observa no exemplo ao final desta subseção.

Finalizada a fase de coleta e sistematização de todos os termos encontrados, realizouse a análise de cada contexto a partir de uma grade principal de análise composta pelos estudos de Olson (2002) e López-Huertas Pérez e Torres Ramírez (2005). 
$\underline{\text { Modelos das fichas de registro }}$

\section{LINGUAGENS DOCUMENTAIS ALFABÉTICAS}

\section{P. ex.: Vocabulário Controlado Básico}

\begin{tabular}{|l|l|}
\cline { 2 - 2 } \multicolumn{1}{c|}{} & \\
\hline Feminina & \\
\hline Femininas & \\
\hline Feminino & $\mathrm{X}$ \\
\hline Femininos & \\
\hline Feminismo & \\
\hline Feminismos & \\
\hline Feminista & \\
\hline Feministas & \\
\hline Materna & \\
\hline Maternal & \\
\hline Materno & \\
\hline Mulher & \\
\hline Mulheres & \\
\hline & \\
\hline
\end{tabular}

Descritor: Trabalho feminino

Nota de escopo: $\quad$ NÃO USE Mulher, emprego

NÃO USE Trabalho da mulher

\section{Relação de equivalência (UP/ USE):}

Relação associativa (TR): Emprego

Gestante

Mercado de trabalho

Mulher

Proteção à maternidade

Salário-maternidade

Relação hierárquica (TG/ TE): TE Licença à gestante

Observação: CDD 341.655 


\section{LINGUAGEM DOCUMENTAL HIERÁRQUICA}

\section{Classificação Decimal de Direito}

\begin{tabular}{|c|c|}
\hline Feminina & \\
\hline Femininas & \\
\hline Feminino & \\
\hline Femininos & \\
\hline Feminismo & \\
\hline Feminismos & \\
\hline Feminista & \\
\hline Feministas & \\
\hline Materna & \\
\hline Maternal & \\
\hline Materno & \\
\hline Mulher & $\mathrm{X}$ \\
\hline Mulheres & \\
\hline
\end{tabular}

Notação: 341.2726

Conceito classificatório: Direitos políticos da mulher

Contexto hierárquico:

341 Direito público

341.2 Direito constitucional

341.27 Direitos Fundamentais. Direitos primordiais. Garantias asseguradas aos cidadãos e associações. Direitos do homem. Liberdades fundamentais. Direitos políticos

341.272 Direitos da Pessoa Humana. O Estado e os indivíduos. Liberdades Públicas

341.2726 Direitos políticos da mulher

Nota:

Observação: Índice:

Direitos, políticos da mulher 341.2726

Mulher

direitos políticos 341.2726 


\subsection{Caracterização geral do corpus da pesquisa}

Foi delimitado como corpus de pesquisa o seguinte conjunto de linguagens documentais: VCB, VCUSP, TAFBN e CDDireito.

Tem-se no VCB e no VUSP as duas linguagens documentais de maior abrangência no país. O primeiro, voltado para uma rede cooperativa de bibliotecas sediadas em Brasília, integrantes dos Poderes Legislativo, Judiciário e Executivo da Administração Federal e do Governo do Distrito Federal; e, o segundo, para o maior sistema de bibliotecas universitárias brasileiro abrangendo as áreas do conhecimento inerentes às atividades de ensino, pesquisa e extensão da Universidade de São Paulo (São Paulo - SP).

A TAFBN consiste em uma adaptação da LCSH para as necessidades informacionais do Brasil realizada e gerenciada pela Fundação Biblioteca Nacional (Rio de Janeiro - RJ).

E, a CDDireito instituiu uma expansão realizada por Carvalho (2002) da classe 340 da CDD, referente ao Direito, e é amplamente utilizada por esse domínio do conhecimento.

Assim, a coleta indireta na LCSH servirá de contraponto de análise, na medida em que é muito utilizada para a catalogação de assunto em bibliotecas brasileiras, bem como já foram objetos de abordagem de autores como Berman (1993).

De modo a sintetizar comparativamente as principais características das linguagens documentais estabelecidas para a parte aplicada da presente pesquisa, elaborou-se o quadro Caracterização do corpus da pesquisa, o qual se encontra no Apêndice A. 


\section{RESULTADOS}

Apresenta-se nesta seção a coleta de dados realizada nas linguagens documentais brasileiras: VCB, VCUSP, TAFBN e CDDireito, a qual gerou um total de 360 fichas de registro. Seguem as incidências de cada termo em cada uma das linguagens e, posteriormente, a discussão dessas incidências a partir das semelhanças e diferenças entre os termos e entre as linguagens documentais analisadas.

\subsection{Apresentação dos resultados}

A coleta de dados no VCB gerou 42 fichas de registro, conforme descrimina a tabela abaixo.

\section{Tabela 1 - Incidências no VCB}

\begin{tabular}{l|c} 
Feminilidade & 1 \\
Feminina & 5 \\
Femininas & 0 \\
Feminino & 3 \\
Femininos & 1 \\
Feminismo & 1 \\
Feminismos & 0 \\
Feminista & 1 \\
Feministas & 0 \\
Materna & 2 \\
Maternal & 0 \\
Materno & 4 \\
Mulher & 19 \\
Mulheres & 5 \\
TOTAL & $\mathbf{4 2}$ \\
\hline
\end{tabular}

Destaca-se que os termos materna e maternal foram encontrados também (4 incidências) nos sentidos de: escola maternal, referente ao jardim de infância; e língua materna. Destaca-se, ainda, que conceitos como Participação social, Nível educacional e Responsabilidade civil permitiam a utilização de especificadores subordinados a determinados conteúdos documentais (p. ex.: Mulher, participação social; Mulher casada, responsabilidade civil), bem como a indivíduos ou grupo de pessoas (p. ex.: Mulher, nível educacional). 
A coleta de dados no VCUSP gerou 59 fichas de registro, conforme descrimina a tabela abaixo. No decorrer da coleta de dados houve a incidência do termo Voz Feminilizada, mas como foi uma incidência isolada, a mesma não foi considerada.

Tabela 2 - Incidências no

\begin{tabular}{l|c}
\multicolumn{2}{c}{ VCUSP } \\
\hline Feminilidade & 1 \\
Feminina & 8 \\
Femininas & 0 \\
Feminino & 7 \\
Femininos & 8 \\
Feminismo & 1 \\
Feminismos & 0 \\
Feminista & 0 \\
Feministas & 0 \\
Materna & 6 \\
Maternal & 0 \\
Materno & 9 \\
Mulher & 12 \\
Mulheres & 7 \\
TOTAL & $\mathbf{5 9}$ \\
\hline
\end{tabular}

O VCUSP é um vocabulário controlado muito bem desenvolvido nos temas dos cursos oferecidos pela Universidade de São Paulo, não abrangendo todos os campos do conhecimento com a mesma intensidade. Destacam-se as áreas de Odontologia e Agronomia.

A coleta de dados na TAFBN gerou 246 fichas de registro, conforme descrimina a tabela abaixo. No decorrer da coleta foi necessário se considerar os termos em inglês: Female, Feminist e Maternal para uma busca mais exaustiva, visto que a TAFBN é uma versão adaptada da LCSH, a qual é originalmente em inglês, conforme já destacado.

Tabela 3 - Incidências na

TAFBN

\begin{tabular}{l|c}
\hline Female (inglês) & 13 \\
Feminilidade & 4 \\
Feminina & 3 \\
Femininas & 1 \\
Feminino & 1 \\
Femininos & 0 \\
Feminismo & 8 \\
Feminismos & 0 \\
Feminist (inglês) & 10 \\
Feminista & 1 \\
Feministas & 0 \\
Materna & 0 \\
Maternal & 0 \\
Maternal (inglês) & 3
\end{tabular}




\begin{tabular}{l|c} 
Materno & 0 \\
Mulher & 4 \\
Mulheres & 198 \\
TOTAL & $\mathbf{2 4 6}$ \\
\hline
\end{tabular}

A TAFBN, por ser uma lista de cabeçalhos de assuntos, mantém todos os termos referentes à mulher sob os cabeçalhos de assunto mulher e mulheres.

Essa linguagem documental busca ser igualitária, pois apesar de uma quantidade significantemente inferior de termos estar inserida sob os cabeçalhos de assunto homem e homens em comparação com a quantidade de termos inserida sob os cabeçalhos de assunto mulher e mulheres, a linguagem designa diversos e variados termos para amparar a questão feminina, mas não é equitativa uma vez que reflete biasses comentadas por López-Huertas Pérez e Torres Ramírez (2005) na página 77, os quais refletem, por sua vez, biasses inerentes à própria linguagem natural.

A coleta de dados na CDDireito gerou 13 fichas de registro, conforme descrimina a tabela abaixo.

\begin{tabular}{l|c}
\multicolumn{2}{c}{ Tabela 4 - Incidências na } \\
CDDireito
\end{tabular}

A CDDireito cumpre sua função enquanto uma expansão da classe 340 (Direito) da CDD com objetivo de inserir especificidades do Direito brasileiro e destinada, primeiramente, à biblioteca do Ministério da Fazenda, e, atualmente, também para a indexação de conteúdos documentais da Base de dados da Legislação Federal do Brasil, mantida pela Subchefia para Assuntos Jurídicos da Casa Civil da Presidência da República.

A comparação dos termos encontrados nas quatro linguagens documentais analisadas, bem como a análise e discussão dos resultados, partirá de um quadro comparativo geral em 
um primeiro momento; e, em um segundo momento, cada categoria extraída desse quadro será discutida no âmbito de cada uma das quatro linguagens documentais.

\subsection{Discussão dos resultados}

Os 360 termos encontrados foram inseridos sob as seguintes categorias, as quais serão discutidas a seguir: Criminalidade; Cultura; Direito; Educação; Feminismo; História; Indivíduo; Maternidade; Religião; Saúde e Esporte; Sexualidade; Sociedade; Trabalho.

Optou-se por manter o quadro abaixo na íntegra no interior do texto para que os leitores tenham acesso aos descritores exatamente da maneira como aparecem nas linguagens documentais trabalhadas, permitindo, assim, melhor visualização das comparações.

\begin{tabular}{|c|c|c|c|}
\hline Categoria & Linguagem & Descritor & $\begin{array}{c}\text { Número da } \\
\text { ficha de registro }\end{array}$ \\
\hline \multirow[t]{26}{*}{ Criminalidade } & \multirow{3}{*}{ CDDireito } & $\begin{array}{l}\text { Instituições penitenciárias para } \\
\text { mulheres e para meninas }\end{array}$ & 011 \\
\hline & & $\begin{array}{l}\text { Mulheres delinquentes } \\
\text { (Alcoólatras, alienadas, prostitutas } \\
\text { etc.) }\end{array}$ & 012 \\
\hline & & Tráfico de mulheres & 009 \\
\hline & \multirow{9}{*}{ TAFBN } & Crime contra as mulheres & 021 \\
\hline & & Criminosas & 022 \\
\hline & & Mulheres homicidas & 115 \\
\hline & & Mulheres maltratadas & 127 \\
\hline & & Prisioneiras & 182 \\
\hline & & Prostituição & 217 \\
\hline & & Violência contra as jovens & 200 \\
\hline & & Violência contra as mulheres & 199 \\
\hline & & Vítimas de abuso sexual & 194 \\
\hline & \multirow{11}{*}{$\mathrm{VCB}$} & Discriminação sexual & 018 \\
\hline & & Lenocínio & 030 \\
\hline & & Mulher delinquente & 002 \\
\hline & & Mulher delinquente & 003 \\
\hline & & Mulher delinquente & 017 \\
\hline & & Penitenciária de mulheres & 007 \\
\hline & & Penitenciária de mulheres & 012 \\
\hline & & Penitenciária de mulheres & 022 \\
\hline & & Penitenciária de mulheres & 023 \\
\hline & & Penitenciária de mulheres & 025 \\
\hline & & Violência contra a mulher & 031 \\
\hline & \multirow[t]{3}{*}{ VCUSP } & Mulher delinquente & 002 \\
\hline & & Prisões para mulheres & 042 \\
\hline & & Violência contra a mulher & 056 \\
\hline
\end{tabular}




\begin{tabular}{|c|c|c|c|}
\hline & & Violência na família (UP) & 005 \\
\hline & & Violência na família (UP) & 006 \\
\hline \multirow{20}{*}{ Cultura } & \multirow{19}{*}{ TAFBN } & Circuncisão feminina & 207 \\
\hline & & Feminilidade na literatura & 221 \\
\hline & & Folclore das mulheres & 040 \\
\hline & & Fotografia de mulheres & 041 \\
\hline & & Mulheres - Biografia & 013 \\
\hline & & Mulheres - Canções e música & 014 \\
\hline & & Mulheres - Coleções literárias & 016 \\
\hline & & Mulheres e literatura & 100 \\
\hline & & Mulheres e paz & 103 \\
\hline & & Mulheres - Linguagem & 050 \\
\hline & & Mulheres na arte & 136 \\
\hline & & Mulheres na cultura popular & 141 \\
\hline & & Mulheres na literatura & 149 \\
\hline & & Mulheres na música & 151 \\
\hline & & Mulheres na ópera & 152 \\
\hline & & Mulheres no cinema & 164 \\
\hline & & Mulheres - Retratos & 056 \\
\hline & & Periódicos para mulheres & 197 \\
\hline & & Rádio e mulheres & 106 \\
\hline & VCUSP & Coro feminino & 016 \\
\hline \multirow{21}{*}{ Direito } & \multirow{8}{*}{ CDDireito } & $\begin{array}{l}\text { Autorização judiciária dada à } \\
\text { mulher casada }\end{array}$ & 006 \\
\hline & & Capacidade jurídica da mulher & 008 \\
\hline & & Direitos da mulher em geral & 004 \\
\hline & & $\begin{array}{l}\text { Direitos do marido sobre os bens da } \\
\text { mulher }\end{array}$ & 005 \\
\hline & & Direitos políticos da mulher & 001 \\
\hline & & $\begin{array}{l}\text { Mulher casada. Autoridade marital. } \\
\text { Autorização marital }\end{array}$ & 003 \\
\hline & & Mulheres e menores comerciantes & 013 \\
\hline & & Voto das mulheres & 010 \\
\hline & \multirow{4}{*}{ TAFBN } & Direitos das mulheres & 026 \\
\hline & & Marido e mulher (Direito) & 004 \\
\hline & & Mulheres - Estatuto legal, leis, etc. & 035 \\
\hline & & Mulheres - Sufrágio & 059 \\
\hline & \multirow{5}{*}{ VCB } & Direitos da mulher & 004 \\
\hline & & Direitos políticos da mulher & 005 \\
\hline & & Estatuto da mulher casada & 008 \\
\hline & & Sociedade comercial entre cônjuges & 027 \\
\hline & & Voto da mulher & 032 \\
\hline & \multirow{4}{*}{ VCUSP } & Direitos da mulher & 017 \\
\hline & & Direitos políticos da mulher & 018 \\
\hline & & Sufrágio feminino & 053 \\
\hline & & Voto da mulher & 057 \\
\hline \multirow[t]{7}{*}{ Educação } & \multirow{6}{*}{ TAFBN } & Educação feminina & 201 \\
\hline & & Educação sanitária para mulheres & 030 \\
\hline & & Educação sexual para mulheres & 031 \\
\hline & & Mulheres de nível superior & 091 \\
\hline & & Mulheres - Ensino profissional & 033 \\
\hline & & Mulheres na educação & 142 \\
\hline & VCB & Educação feminina & 006 \\
\hline
\end{tabular}




\begin{tabular}{|c|c|c|c|}
\hline & & Educação feminina & 020 \\
\hline & VCUSP & Educação feminina & 022 \\
\hline \multirow{24}{*}{ Feminismo } & \multirow{19}{*}{ TAFBN } & Cinema feminista & 231 \\
\hline & & Crítica feminista & 232 \\
\hline & & $\begin{array}{l}\text { - Crítica feminista (Subdivisão } \\
\text { controlada para obras sagradas) }\end{array}$ & 246 \\
\hline & & Crítica literária feminista & 234 \\
\hline & & Ecofeminismo & 230 \\
\hline & & Estudos feministas & 238 \\
\hline & & Ética feminina & 233 \\
\hline & & Feminismo & 223 \\
\hline & & $\begin{array}{l}\text { Feminismo - Aspectos religiosos - } \\
\text { Cristianismo }\end{array}$ & 224 \\
\hline & & Feminismo e ciência & 228 \\
\hline & & Feminismo e educação & 225 \\
\hline & & Feminismo e literatura & 226 \\
\hline & & Feminismo na literatura & 229 \\
\hline & & Feministas & 240 \\
\hline & & Psicanálise e feminismo & 227 \\
\hline & & Psicologia feminista & 235 \\
\hline & & Teologia feminista & 239 \\
\hline & & Teoria feminista & 237 \\
\hline & & Terapia feminista & 236 \\
\hline & \multirow{3}{*}{$\mathrm{VCB}$} & Feminismo & 011 \\
\hline & & Feminismo & 014 \\
\hline & & Feminismo & 037 \\
\hline & \multirow{2}{*}{ VCUSP } & Feminismo & 004 \\
\hline & & Feminismo & 009 \\
\hline \multirow{6}{*}{ História } & \multirow{5}{*}{ TAFBN } & Mulheres - História & 043 \\
\hline & & $\begin{array}{l}\text { Mulheres - História - Idade Média, } \\
500-1500\end{array}$ & 046 \\
\hline & & $\begin{array}{l}\text { Mulheres - História - Renascença, } \\
\text { 1450-1600 }\end{array}$ & 045 \\
\hline & & $\begin{array}{l}\text { Mulheres - História - Período } \\
\text { moderno, 1600- }\end{array}$ & 044 \\
\hline & & $\begin{array}{l}\text { Mulheres no cristianismo - História } \\
\text { - Igreja primitiva, ca. } 30-600\end{array}$ & 144 \\
\hline & VCUSP & História da mulher & 031 \\
\hline \multirow[t]{15}{*}{ Indivíduo } & \multirow[t]{15}{*}{ TAFBN } & Amizade entre mulheres & 209 \\
\hline & & Autoaceitação em mulheres & 011 \\
\hline & & Autoestima em mulheres & 006 \\
\hline & & Autorrealização em mulheres & 012 \\
\hline & & Beleza feminina (Estética) & 203 \\
\hline & & Calvície em mulheres & 216 \\
\hline & & Defesa pessoal para mulheres & 024 \\
\hline & & Etiqueta feminina & 202 \\
\hline & & Feminilidade & 219 \\
\hline & & Feminilidade (Filosofia) & 220 \\
\hline & & Grávidas & 113 \\
\hline & & Lesbianismo & 212 \\
\hline & & Lésbicas & 116 \\
\hline & & Menopausa & 206 \\
\hline & & Mulher (Filosofia) & 001 \\
\hline
\end{tabular}




\begin{tabular}{|c|c|c|c|}
\hline & & $\begin{array}{l}\text { Mulheres (Subdivisão controlada } \\
\text { para serviços militares (não pode } \\
\text { ser subdividido por local) e para } \\
\text { guerras) }\end{array}$ & 244 \\
\hline & & Mulheres brancas & 069 \\
\hline & & Mulheres casadas & 071 \\
\hline & & Mulheres de meia-idade & 089 \\
\hline & & Mulheres divorciadas & 093 \\
\hline & & Mulheres fatais & 111 \\
\hline & & Mulheres - Identidade & 049 \\
\hline & & Mulheres idosas & 117 \\
\hline & & Mulheres índias & 121 \\
\hline & & $\begin{array}{l}\text { Mulheres iranianas de origem } \\
\text { americana }\end{array}$ & 123 \\
\hline & & Mulheres jovens & 125 \\
\hline & & Mulheres saaráuis & 186 \\
\hline & & Mulheres solteiras & 187 \\
\hline & & Negras & 162 \\
\hline & & Personificadores femininos & 213 \\
\hline & & Relações homem-mulher & 218 \\
\hline & & Roupas femininas & 204 \\
\hline & & Roupas íntimas femininas & 198 \\
\hline & \multirow{6}{*}{ VCB } & Cônjuge & 013 \\
\hline & & Feminilidade (Psicologia) & 010 \\
\hline & & Lesbianismo & 035 \\
\hline & & Mulher & 015 \\
\hline & & Mulher casada & 016 \\
\hline & & Mulher divorciada & 019 \\
\hline & \multirow{7}{*}{ VCUSP } & Estereótipos (Psicologia) & 026 \\
\hline & & Feminilidade & 059 \\
\hline & & Moda feminina & 037 \\
\hline & & Mulher casada & 001 \\
\hline & & Relações homem-mulher & 047 \\
\hline & & Vestuário feminino & 055 \\
\hline & & Voz feminina & 058 \\
\hline \multirow{18}{*}{ Maternidade } & & Amor materno & 242 \\
\hline & TAFBN & Carência materna & 241 \\
\hline & & Mães (TG: Mulheres) & 243 \\
\hline & & Aleitamento materno & 001 \\
\hline & $\mathrm{VCR}$ & Leite materno & 041 \\
\hline & $\mathrm{VCB}$ & Mortalidade materna & 038 \\
\hline & & Nutrição materna & 039 \\
\hline & & Aleitamento materno & 010 \\
\hline & & Amor materno & 011 \\
\hline & & Ausência materna & 012 \\
\hline & & Comportamento materno animal & 014 \\
\hline & & Enfermagem materno-infantil & 024 \\
\hline & VCUSP & Exposição materna & 027 \\
\hline & & Idade materna & 033 \\
\hline & & Mortalidade materna & 038 \\
\hline & & Relações mãe-criança & 015 \\
\hline & & Relações mãe-criança & 043 \\
\hline & & Substitutos do leite humano (UP) & 052 \\
\hline
\end{tabular}




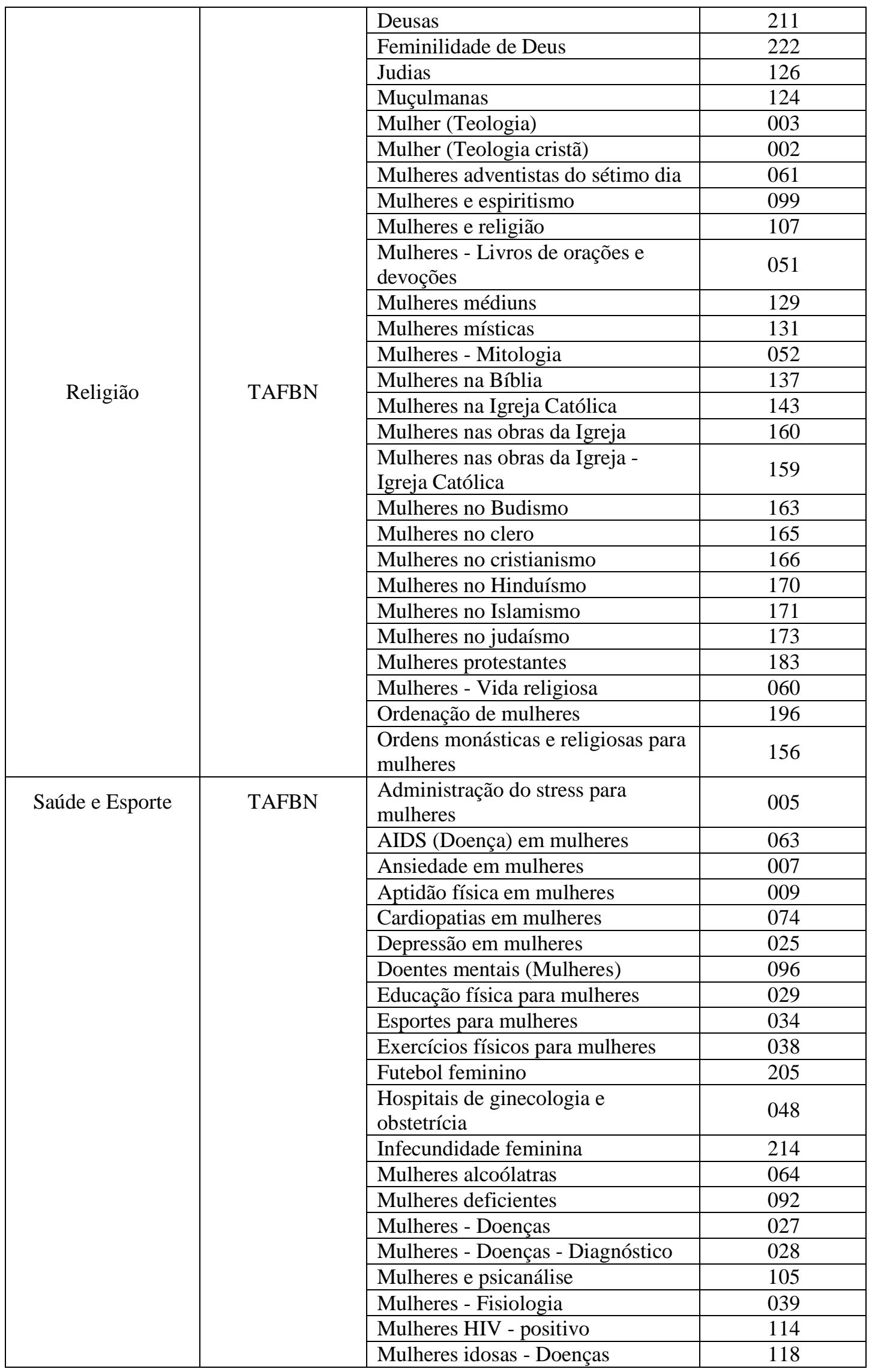




\begin{tabular}{|c|c|c|c|}
\hline & & Mulheres - Nutrição & 053 \\
\hline & & Mulheres - Psicologia & 054 \\
\hline & & Mulheres - Saúde e higiene & 042 \\
\hline & & Mulheres - Saúde mental & 058 \\
\hline & & Mulheres surfistas & 188 \\
\hline & & Obesidade em mulheres & 177 \\
\hline & & Parapsicologia e mulheres & 102 \\
\hline & & Serviços de saúde para mulheres & 023 \\
\hline & \multirow{4}{*}{ VCB } & Psicologia da mulher & 024 \\
\hline & & Saúde da mulher & 026 \\
\hline & & Saúde materno-infantil & 040 \\
\hline & & Saúde materno-infantil & 042 \\
\hline & \multirow{18}{*}{ VCUSP } & Centros de saúde materno-infantil & 013 \\
\hline & & Doenças dos genitais femininos & 020 \\
\hline & & Doenças dos genitais femininos & 021 \\
\hline & & Doenças dos genitais femininos & 030 \\
\hline & & Educação física feminina & 023 \\
\hline & & $\begin{array}{l}\text { Escala de segmento de mulheres } \\
\text { alccolistas }\end{array}$ & 025 \\
\hline & & Ginástica feminina & 029 \\
\hline & & Imunidade materno-adquirida & 034 \\
\hline & & Infertilidade feminina & 035 \\
\hline & & Mulher no esporte & 003 \\
\hline & & Neoplasias dos genitais femininos & 039 \\
\hline & & Neoplasias dos genitais femininos & 040 \\
\hline & & Psicologia da mulher & 045 \\
\hline & & Psicologia da mulher & 046 \\
\hline & & Saúde da mulher & 048 \\
\hline & & Saúde materno-infantil & 049 \\
\hline & & Serviços de saúde da mulher & 050 \\
\hline & & Serviços de saúde materna & 051 \\
\hline \multirow{14}{*}{ Sexualidade } & CDDireito & Sexo. Condição da mulher & 002 \\
\hline & \multirow{5}{*}{ TAFBN } & Aparelho genital feminino & 210 \\
\hline & & Esterilização de mulheres & 036 \\
\hline & & Hormônios sexuais & 047 \\
\hline & & Mulheres - Comportamento sexual & 018 \\
\hline & & Orgasmo feminino & 215 \\
\hline & \multirow{4}{*}{ VCB } & Aparelho genital feminino & 034 \\
\hline & & Aparelho genital feminino & 036 \\
\hline & & $\begin{array}{l}\text { Esterilização (controle de } \\
\text { natalidade) }\end{array}$ & 009 \\
\hline & & $\begin{array}{l}\text { Esterilização (controle de } \\
\text { natalidade) }\end{array}$ & 033 \\
\hline & \multirow{4}{*}{ VCUSP } & $\begin{array}{l}\text { Dispositivos anticoncepcionais } \\
\text { femininos }\end{array}$ & 019 \\
\hline & & Genitália feminina & 028 \\
\hline & & Hormônios sexuais femininos & 032 \\
\hline & & Orgasmo feminino & 041 \\
\hline \multirow[t]{4}{*}{ Sociedade } & \multirow[t]{4}{*}{ TAFBN } & $\begin{array}{l}\text { Áreas subdesenvolvidas - Mulheres } \\
\text { do campo }\end{array}$ & 095 \\
\hline & & Consumidoras & 076 \\
\hline & & Internet e mulheres & 097 \\
\hline & & Mulheres - Antropometria & 008 \\
\hline
\end{tabular}




\begin{tabular}{|c|c|c|c|}
\hline & & Mulheres - Aspectos sociológicos & 010 \\
\hline & & Mulheres chefes de família & 072 \\
\hline & & Mulheres comunistas & 085 \\
\hline & & Mulheres - Conduta & 017 \\
\hline & & Mulheres - Condição sociais & 020 \\
\hline & & Mulheres da cidade & 087 \\
\hline & & Mulheres de classe alta & 088 \\
\hline & & Mulheres do campo & 094 \\
\hline & & Mulheres e maçonaria & 101 \\
\hline & & Mulheres e planejamento urbano & 104 \\
\hline & & Mulheres e socialismo & 108 \\
\hline & & $\begin{array}{l}\text { Mulheres em associações sem fins } \\
\text { lucrativos }\end{array}$ & 109 \\
\hline & & Mulheres - Evolução & 037 \\
\hline & & Mulheres imigrantes & 120 \\
\hline & & Mulheres na comunicação de massa & 140 \\
\hline & & Mulheres na imprensa & 145 \\
\hline & & $\begin{array}{l}\text { Mulheres na indústria } \\
\text { cinematográfica }\end{array}$ & 146 \\
\hline & & $\begin{array}{l}\text { Mulheres na indústria de } \\
\text { comunicação de massa }\end{array}$ & 147 \\
\hline & & Mulheres na política & 153 \\
\hline & & Mulheres na propaganda & 154 \\
\hline & & Mulheres na radiodifusão & 155 \\
\hline & & Mulheres na teledifusão & 148 \\
\hline & & Mulheres na vida pública & 158 \\
\hline & & Mulheres no desenvolvimento & 098 \\
\hline & & $\begin{array}{l}\text { Mulheres no desenvolvimento da } \\
\text { comunidade }\end{array}$ & 167 \\
\hline & & $\begin{array}{l}\text { Mulheres no desenvolvimento } \\
\text { econômico }\end{array}$ & 168 \\
\hline & & Mulheres no desenvolvimento rural & 169 \\
\hline & & Mulheres nos sindicatos & 176 \\
\hline & & Mulheres pobres & 180 \\
\hline & & Mulheres - Recreação & 055 \\
\hline & & Mulheres - Sociedades e clubes & 015 \\
\hline & VCUSP & Programa feminino & 044 \\
\hline Trabalho & CDDireito & $\begin{array}{l}\text { Trabalho da mulher. Proteção à } \\
\text { maternidade }\end{array}$ & 007 \\
\hline & TAFBN & Advogadas & 062 \\
\hline & & Arquitetas & 065 \\
\hline & & Aviadoras & 068 \\
\hline & & Compositoras & 084 \\
\hline & & Dramaturgas brasileiras & 070 \\
\hline & & Engenheiras & 110 \\
\hline & & Escritoras & 075 \\
\hline & & Estudantes universitárias & 191 \\
\hline & & Executivas & 133 \\
\hline & & Ferroviárias & 112 \\
\hline & & Filósofas & 077 \\
\hline & & Fotógrafas & 078 \\
\hline & & Legisladoras & 086 \\
\hline & & Médicas & 128 \\
\hline
\end{tabular}




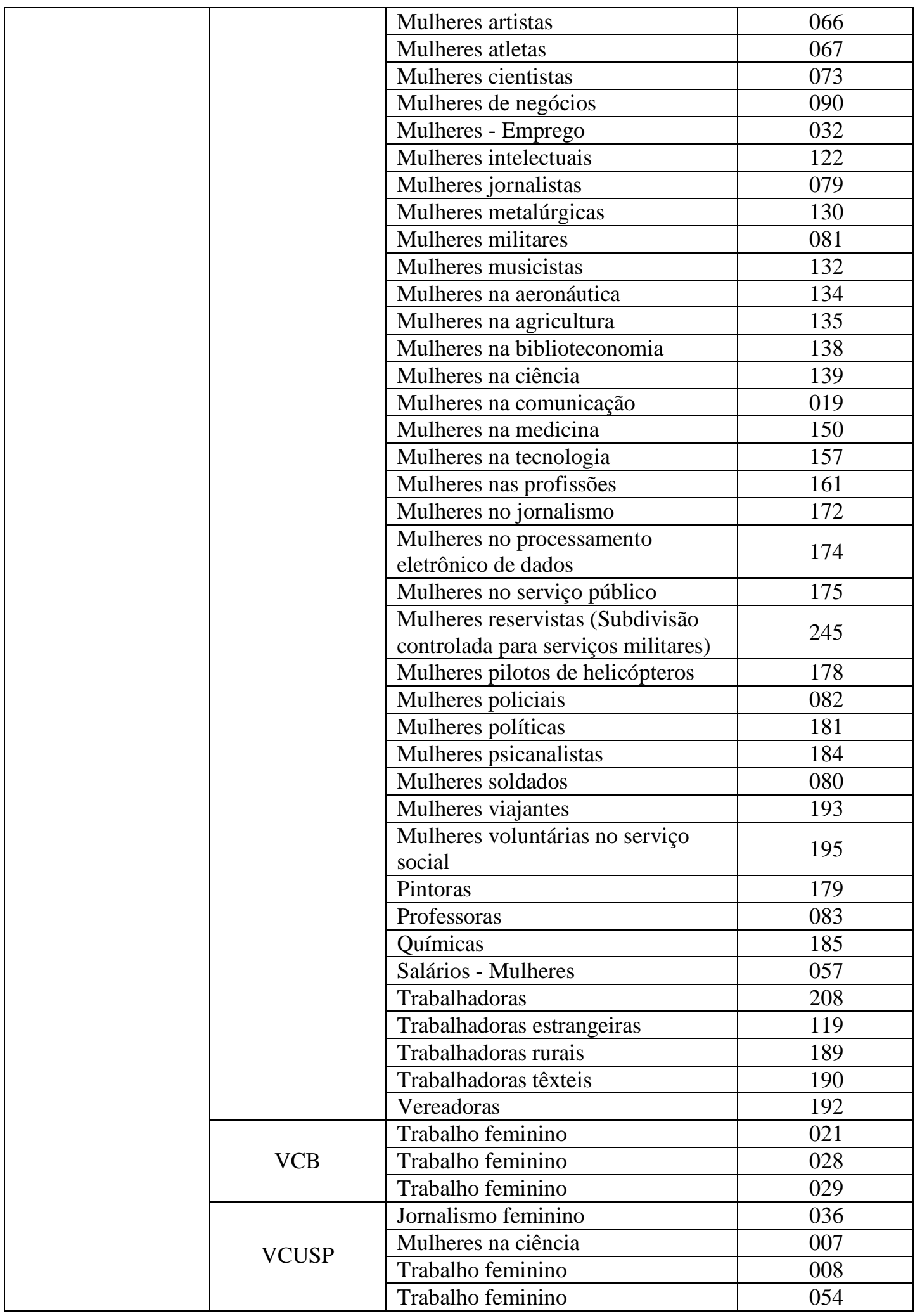

Quadro 1 - Categorização dos termos encontrados nas quatro linguagens documentais brasileiras analisadas

Fonte: Elaborado pela autora. 
A respeito do quadro apresentado, ressalta-se que os termos que aparecem repetidos na mesma linguagem documental dizem respeito ao número de remissivas que os compõem, lembrando que as remissivas são recursos utilizados pelas linguagens documentais para indicar qual é o descritor permitido pela linguagem para representar determinado conceito; sendo assim, os tesauros indicam uma a uma das remissivas que cada descritor contém.

Ressalta-se ainda que os conceitos seguidos pela sigla (UP - usado para) são conceitos cujos termos que foram objeto de busca da presente pesquisa apareceram na remissiva e não no descritor permitido.

Informações adicionais foram colocadas entre parênteses após o conceito, como quando o conceito faz parte de um índice diferente: Subdivisões de assunto, por exemplo.

Dos 360 termos encontrados, 108 descritores encontraram descritor ou descritores semelhantes em uma ou mais linguagens documentais e 252 descritores não encontraram semelhantes e permaneceram isolados.

Explica-se que para uma melhor visualização dos leitores, os termos que foram objetos de busca (feminilidade; feminina(s); feminino(s); feminismo(s); feminista(s); materna(o); maternal; mulher(es)) foram suprimidos dos descritores nos quadros.

\section{Criminalidade}

\begin{tabular}{|c|c|c|c|}
\hline \multicolumn{4}{|c|}{ Semelhantes } \\
\hline Categoria & Linguagem & Descritor & $\begin{array}{c}\text { Número da } \\
\text { ficha de registro }\end{array}$ \\
\hline \multirow[t]{18}{*}{ Criminalidade } & \multirow{5}{*}{ CDDireito } & $\begin{array}{l}\text { Instituições penitenciárias para } \\
\text { mulheres e para meninas }\end{array}$ & 011 \\
\hline & & $\begin{array}{l}\text { delinquentes (Alcoólatras, } \\
\text { alienadas, prostitutas etc.) }\end{array}$ & 012 \\
\hline & & Tráfico & 009 \\
\hline & & Violência contra as jovens & 200 \\
\hline & & Violência contra & 199 \\
\hline & TAFBN & & \\
\hline & \multirow{10}{*}{ VCB } & Lenocínio & 030 \\
\hline & & delinquente & 002 \\
\hline & & delinquente & 003 \\
\hline & & delinquente & 017 \\
\hline & & Penitenciária & 007 \\
\hline & & Penitenciária & 012 \\
\hline & & Penitenciária & 022 \\
\hline & & Penitenciária & 023 \\
\hline & & Penitenciária & 025 \\
\hline & & Violência contra & 031 \\
\hline & \multirow[t]{2}{*}{ VCUSP } & delinquente & 002 \\
\hline & & Prisões & 042 \\
\hline
\end{tabular}




\begin{tabular}{|c|c|c|c|}
\hline & & Violência contra & 056 \\
\hline & & Violência na família (UP) & 005 \\
\hline & & Violência na família (UP) & 006 \\
\hline
\end{tabular}

\begin{tabular}{|c|c|c|c|}
\hline \multicolumn{4}{|c|}{ Diferentes } \\
\hline Categoria & Linguagem & Descritor & $\begin{array}{c}\text { Número da } \\
\text { ficha de registro }\end{array}$ \\
\hline \multirow{10}{*}{ Criminalidade } & CDDireito & & \\
\hline & \multirow{7}{*}{ TAFBN } & Crime contra & 021 \\
\hline & & Criminosas & 022 \\
\hline & & homicidas & 115 \\
\hline & & maltratadas & 127 \\
\hline & & Prisioneiras & 182 \\
\hline & & Prostituição & 217 \\
\hline & & Vítimas de abuso sexual & 194 \\
\hline & VCB & Discriminação sexual & 018 \\
\hline & VCUSP & & \\
\hline
\end{tabular}

Em relação à violência doméstica, o VCUSP insere o descritor Maus-tratos conjugais em Saúde Pública. Bias: Os problemas de maus-tratos não ocorrem necessariamente a partir de aspectos relacionados à saúde, desse modo não deveriam estar inseridos apenas e especificamente nessa classe.

O VCUSP estabelece o descritor Violência na família UP Mulheres espancadas e UP Mulheres maltratadas. Bias: Utilizar um descritor genérico (família) para representar agressões a um indivíduo específico (mulher).

A CDDireito estabelece o conceito classificatório Mulheres delinquentes (Alcoólatras, alienadas, prostitutas etc.) a partir da seguinte hierarquia:

341 Direito público

341.5 Direito penal

341.59 Criminologia e antropologia, sociologia e tecnologia criminais

341.591 Delinquentes ou criminosos e suas espécies

341.5914 Mulheres delinquentes (Alcoólatras, alienadas, prostitutas etc.)

Biasses: Primeiramente, Alcoólatras e Alienadas deveriam estar amparadas em classes relacionadas à saúde e apenas Prostitutas poderia estar inserido sob criminalidade, uma vez que no Brasil a prostituição é considerada ilegal e crime, mas nenhuma dessas especificidades deveria estar inserida sob o descritor Mulheres delinquentes. Em segundo lugar, a hierarquia denota que Mulher delinquente não se insere nos delitos já citados acima, figurando dessa maneira, como um tipo específico de deliquente ou criminoso. 
Em relação a delinquência, o VCUP insere sob Delinquente, as seguintes especificidades: Deliquente juvenil, Deliquente habitual, Deliquente Passional, Delinquente político, Delinquente sexual, Mulher delinquente. Bias: Denota que Mulher delinquente é uma espécie de delinquência e de criminoso.

As duas últimas biasses seriam amenizadas com a não-ausência do masculino, ou seja, caso essa especificação for realmente necessária, essa diferenciação deve ser feita a partir de qualificadores de gênero.

A CDDireito apresenta a seguinte hierarquia para o conceito classificatório Instituições penitenciárias para mulheres e para meninas:

341 Direito público 341.5 Direito penal 341.58 Direito Penitenciário. Direito de Execuções Penais (Ciência penitenciária. Penologia. Ciência repressiva. Política criminal em geral. Execução das penas. Tratamento dos criminosos. Regimes, sistemas penitenciários)

341.581 Estabelecimentos penitenciários 341.5819 Outros estabelecimentos penitenciários

341.58192 Instituições penitenciárias para mulheres e para meninas

Biasses: Inserir Instituições penitenciárias para mulheres e para meninas abaixo de Outros estabelecimentos penitenciários é uma especificidade desnecessária que torna as instituições em questão marginais, sendo que abaixo de Estabelecimentos penitenciários poderiam constar Instituições penitenciárias para homens e para meninos e Instituições penitenciárias para mulheres e para meninas. Outra bias já salientada por Santos, Madina e Serra (1999) se dá pelo fato de não haver um critério para determinar mulheres e meninas, nem um critério de idade para pertencer a cada instituição.

Em síntese, em relação à criminalidade, há uma tendência em tratar as mulheres como exceções as normas masculinas (OLSON, 2002) e a considerar generalidade como masculinidade (LÓPEZ-HUERTAS PÉREZ; TORRES RAMÍREZ, 2005).

\section{Cultura}

\begin{tabular}{|c|c|c|c|}
\hline \multicolumn{4}{|c|}{ Semelhantes } \\
\hline \multirow{2}{*}{ Categoria } & Linguagem & Descritor & $\begin{array}{c}\text { Número da } \\
\text { ficha de registro }\end{array}$ \\
\hline \multirow{2}{*}{ Cultura } & TAFBN & & \\
\cline { 2 - 4 } & VCUSP & & \\
\hline
\end{tabular}




\begin{tabular}{|c|c|c|c|}
\hline \multicolumn{4}{|c|}{ Diferentes } \\
\hline Categoria & Linguagem & Descritor & $\begin{array}{c}\text { Número da } \\
\text { ficha de registro }\end{array}$ \\
\hline \multirow{20}{*}{ Cultura } & \multirow{19}{*}{ TAFBN } & Circuncisão & 207 \\
\hline & & Feminilidade na literatura & 221 \\
\hline & & Folclore das & 040 \\
\hline & & Fotografia de & 041 \\
\hline & & Biografia & 013 \\
\hline & & Canções e música & 014 \\
\hline & & Coleções literárias & 016 \\
\hline & & e literatura & 100 \\
\hline & & e paz & 103 \\
\hline & & Linguagem & 050 \\
\hline & & arte & 136 \\
\hline & & cultura popular & 141 \\
\hline & & literatura & 149 \\
\hline & & música & 151 \\
\hline & & ópera & 152 \\
\hline & & cinema & 164 \\
\hline & & Retratos & 056 \\
\hline & & Periódicos para & 197 \\
\hline & & Rádio e & 106 \\
\hline & VCUSP & Coro & 016 \\
\hline
\end{tabular}

Ressalta-se que da mesma maneira que há Periódicos para mulheres há também Periódicos para homens. Bias: Essa especificidade em relação ao sexo deveria ocorrer em todos quesitos do quadro acima ou deveria ser utilizado o modo genérico juntamente com qualificadores de gênero, pois da maneira como se apresenta remete a uma ideia de tratamento "excepcional" dado ao feminino.

Em síntese, em relação aos aspectos culturais, amparados apenas pela TAFBN e por uma incidência no VCUSP há uma tendência em tratar as mulheres como exceções as normas masculinas (OLSON, 2002), mas como tentativa de incluí-las.

\section{Direito}

\begin{tabular}{|c|c|c|c|}
\hline \multicolumn{4}{|c|}{ Semelhantes } \\
\hline Categoria & Linguagem & Descritor & $\begin{array}{c}\text { Número da } \\
\text { ficha de registro }\end{array}$ \\
\hline \multirow[t]{8}{*}{ Direito } & \multirow{3}{*}{ CDDireito } & Direitos em geral & 004 \\
\hline & & Direitos políticos & 001 \\
\hline & & Voto & 010 \\
\hline & \multirow{2}{*}{ TAFBN } & Direitos & 026 \\
\hline & & Sufrágio & 059 \\
\hline & \multirow{3}{*}{ VCB } & Direitos & 004 \\
\hline & & Direitos políticos & 005 \\
\hline & & Voto & 032 \\
\hline
\end{tabular}




\begin{tabular}{|l|l|l|l|}
\hline \multirow{3}{*}{ VCUSP } & Direitos & 017 \\
\cline { 3 - 3 } & Direitos políticos & 018 \\
\cline { 3 - 3 } & Sufrágio & 053 \\
\cline { 3 - 4 } & Voto & 057 \\
\hline
\end{tabular}

\begin{tabular}{|c|c|c|c|}
\hline \multicolumn{4}{|c|}{ Diferentes } \\
\hline Categoria & Linguagem & Descritor & $\begin{array}{c}\text { Número da } \\
\text { ficha de registro }\end{array}$ \\
\hline \multirow{10}{*}{ Direito } & \multirow{5}{*}{ CDDireito } & $\begin{array}{l}\text { Autorização judiciária dada à } \\
\text { mulher casada }\end{array}$ & 006 \\
\hline & & Capacidade jurídica & 008 \\
\hline & & $\begin{array}{l}\text { Direitos do marido sobre os bens da } \\
\text { mulher }\end{array}$ & 005 \\
\hline & & $\begin{array}{lll}\text { casada. Autoridade marital. } \\
\text { Autorização marital }\end{array}$ & 003 \\
\hline & & Mulheres e menores comerciantes & 013 \\
\hline & \multirow{2}{*}{ TAFBN } & Marido e mulher (Direito) & 004 \\
\hline & & Estatuto legal, leis, etc. & 035 \\
\hline & \multirow{2}{*}{ VCB } & Estatuto da mulher casada & 008 \\
\hline & & Sociedade comercial entre cônjuges & 027 \\
\hline & VCUSP & & \\
\hline
\end{tabular}

A CDDireito insere a seguinte hierarquia para o conceito classificatório Direitos da mulher em geral:

342 Direito privado

342.1 Direito civil

342.16 Direito de família

342.162 Casamento

342.1625 Efeitos do casamento sobre a pessoa dos cônjuges. Deveres e direitos dos cônjuges

342.16252 Mulher casada. Autoridade marital. Autorização marital

342.162522 Direitos da mulher em geral

Bias: O conceito que abrigaria os direitos gerais das mulheres está inserido sob uma condição conjugal Mulher casada. Autoridade marital. Autorização marital, criando uma noção falsa de dependência das temáticas.

A CDDireito insere, ainda, a seguinte hierarquia para o conceito classificatório Sexo. Condição da mulher:

342 Direito privado

342.1 Direito civil

342.11 Parte geral

342.115 Pessoas naturais. Circunstâncias que influem sobre o estado e a capacidade jurídica

342.1156 Sexo. Condição da mulher 
Bias: Aspectos ligados ao sexo não influem diretamente sobre o estado e a capacidade jurídica de nenhum indivíduo.

Em síntese, em relação ao Direito há uma tentativa de salientar os direitos da mulher somente a partir dos direitos políticos que por sua vez são amparados apenas pelo direito que a mesma tem ao voto. Esse aspecto é uma resposta a uma significativa e antiga luta das mulheres, mas os direitos das mulheres englobam muito mais especificidades do que as apresentadas pelas linguagens analisadas. Ou seja, percebe-se a omissão de várias questões inteiramente (OLSON, 2002).

Educação

\begin{tabular}{|c|c|l|c|}
\hline \multicolumn{3}{|c|}{ Semelhantes } \\
\hline \multirow{2}{*}{ Categoria } & Linguagem & \multicolumn{1}{|c|}{ Descritor } & $\begin{array}{c}\text { Número da } \\
\text { ficha de registro }\end{array}$ \\
\hline \multirow{3}{*}{ Educação } & TAFBN & Educação & 201 \\
\cline { 2 - 4 } & \multirow{2}{*}{ VCB } & Educação & 006 \\
\cline { 2 - 4 } & VCUSP & Educaçação & 020 \\
\cline { 2 - 4 } & VCUa & 022 \\
\hline
\end{tabular}

\begin{tabular}{|l|c|l|c|}
\hline \multicolumn{2}{|c|}{ Diferentes } \\
\hline \multirow{4}{*}{ Categoria } & \multirow{2}{*}{ Linguagem } & \multicolumn{1}{c|}{ Descritor } & $\begin{array}{c}\text { Número da } \\
\text { ficha de registro }\end{array}$ \\
\hline \multirow{4}{*}{ Educação } & \multirow{3}{*}{ TAFBN } & Educação sanitária & 030 \\
\cline { 3 - 4 } & & Educação sexual & 031 \\
\cline { 3 - 4 } & & nível superior & 091 \\
\cline { 3 - 4 } & & Ensino profissional & 033 \\
\cline { 3 - 4 } & VCB & & 142 \\
\cline { 3 - 4 } & VCUSP & & \\
\cline { 2 - 4 } & & & \\
\hline
\end{tabular}

As três linguagens consideram a educação das mulheres como um tipo específico de educação e demonstram isso em suas hierarquias, mas apenas o VCUSP explicita tal fato quando utiliza o termo tipo, conforme demonstra a seguinte hierarquia:

CH771 Educação

CH771.12 Tipos de educação

CH771.12.9 Educação feminina

Bias: Há a necessidade de inserir questões femininas nas discussões sobre a educação e os processos de educação em todos os níveis de aprendizado, mas o masculino deve ser repensado da mesma maneira, uma vez que é ainda considerado como genérico ou padrão. 
Tanto na TAFBN quanto no VCB, o descritor Educação sanitária figura como TE, sendo na primeira linguagem como TE do descritor Educação feminina e na segunda como TE do descritor Educação. Bias: Aspectos ligados à educação sanitária não necessitam incluir qualificadores de gênero. No tocante ao VCB, não há coerência em colocar Educação feminina e Educação sanitária, entre outros, em um mesmo nível, ou seja, como TE.

Em síntese, em relação à educação há uma tendência em tratar as mulheres como exceções as normas masculinas (OLSON, 2002) e a considerar generalidade como masculinidade (LÓPEZ-HUERTAS PÉREZ; TORRES RAMÍREZ, 2005).

Feminismo

\begin{tabular}{|c|c|l|c|}
\hline \multicolumn{2}{|c|}{ Semelhantes } \\
\hline \multirow{4}{*}{ Categoria } & \multirow{2}{*}{ Linguagem } & \multicolumn{1}{|c|}{ Descritor } & $\begin{array}{c}\text { Número da } \\
\text { ficha de registro }\end{array}$ \\
\hline \multirow{3}{*}{ Feminismo } & TAFBN & Feminismo & 223 \\
\cline { 2 - 4 } & \multirow{2}{*}{ VCB } & Feminismo & 011 \\
\cline { 2 - 4 } & \multirow{2}{*}{ VCUSP } & Feminismo & 014 \\
\cline { 2 - 4 } & & Feminismo & 037 \\
\cline { 2 - 4 } & & Feminismo & 004 \\
\cline { 2 - 4 } & & Feminismo & 009 \\
\hline
\end{tabular}

\begin{tabular}{|c|c|c|c|}
\hline \multicolumn{4}{|c|}{ Diferentes } \\
\hline Categoria & Linguagem & Descritor & \begin{tabular}{|c|} 
Número da \\
ficha de registro
\end{tabular} \\
\hline \multirow{20}{*}{ Feminismo } & \multirow{18}{*}{ TAFBN } & Cinema & 231 \\
\hline & & Crítica & 232 \\
\hline & & $\begin{array}{l}\text { - Crítica (Subdivisão controlada } \\
\text { para obras sagradas) }\end{array}$ & 246 \\
\hline & & Crítica literária & 234 \\
\hline & & Ecofeminismo & 230 \\
\hline & & Estudos & 238 \\
\hline & & Ética & 233 \\
\hline & & Aspectos religiosos - Cristianismo & 224 \\
\hline & & e ciência & 228 \\
\hline & & e educação & 225 \\
\hline & & e literatura & 226 \\
\hline & & na literatura & 229 \\
\hline & & Feministas & 240 \\
\hline & & Psicanálise & 227 \\
\hline & & Psicologia & 235 \\
\hline & & Teologia & 239 \\
\hline & & Teoria & 237 \\
\hline & & Terapia & 236 \\
\hline & VCB & & \\
\hline & VCUSP & & \\
\hline
\end{tabular}


Em relação ao feminismo, destaca-se que o mesmo foi representado como um movimento social e que a TAFBN inseriu excelentes relações de equivalência e hierárquica, como se vê a seguir:

Relação de equivalência (UP/USE): Emancipação das mulheres; Emancipation of women; Liberação das mulheres; Movimento de liberação das mulheres; Movimento feminista; Women - Emancipation; Women's lib; Women's liberation; Women's liberation movement; Women's movement.

\section{Relação hierárquica (TG/TE):}

TE Discriminação de sexo às mulheres

TE Ecofeminismo

TE Feministas

TE Mulheres - Condições sociais

TE Mulheres - Estatuto legal, leis, etc.

TE Mulheres - História

TE Psicanálise e feminismo

TE Teoria feminista

TE Terapia feminista

TG Movimentos sociais

O VCUSP também tenta ser inclusivo quando apresenta homens e mulheres na estrutura hierárquica do descritor Feminismo:

CH764 Ciências Sociais

CH764.5 Sociologia

CH764.5.4 Gêneros (Grupos sociais)

CH764.5.4.1 Homens

CH764.5.4.2 Mulheres

CH764.5.4.2.1 Feminismo

Bias: Atualmente, o feminismo consiste em um movimento que ampara tanto mulheres como homens em suas lutas e reflexões, conforme demonstra a discussão sobre as ondas do feminismo, que se inicia na página 69.

Em síntese, as linguagens documentais alfabéticas ampararam esse importante quesito que envolve as mulheres, mas apenas a TAFBN explorou o Feminismo mais afundo e disponibilizou descritores que compõem as contribuições metodológicas do Feminismo, bem como seu impacto em algumas áreas da ciência. 
História

\begin{tabular}{|c|c|l|c|}
\hline \multicolumn{4}{|c|}{ Semelhantes } \\
\hline \multirow{2}{*}{ Categoria } & Linguagem & \multicolumn{1}{|c|}{ Descritor } & $\begin{array}{c}\text { Número da } \\
\text { ficha de registro }\end{array}$ \\
\hline \multirow{2}{*}{ História } & TAFBN & História & 043 \\
\cline { 2 - 4 } & VCUSP & História da & 031 \\
\hline
\end{tabular}

\begin{tabular}{|c|c|l|c|}
\hline \multicolumn{4}{|c|}{ Diferentes } \\
\hline \multirow{2}{*}{ Categoria } & \multirow{2}{*}{ Linguagem } & \multicolumn{1}{|c|}{ Descritor } & $\begin{array}{c}\text { Número da } \\
\text { ficha de registro }\end{array}$ \\
\hline \multirow{3}{*}{ História } & \multirow{3}{*}{ TAFBN } & História - Idade Média, 500-1500 & 046 \\
\cline { 3 - 4 } & & História - Renascença, 1450-1600 & 045 \\
\cline { 3 - 4 } & & $\begin{array}{l}\text { História - Período moderno, 1600- } \\
\text { no cristianismo - História - Igreja } \\
\text { primitiva, ca. 30-600 }\end{array}$ & 044 \\
\cline { 3 - 4 } & VCUSP & & 144 \\
\hline
\end{tabular}

A TAFBN disponibiliza uma nota de escopo referente ao descritor Mulheres História, que explica que além de englobar a história específica das mulheres, engloba também a participação das mulheres na História "geral":

Nota de escopo: Usado para obras que tratam da história das mulheres, incluindo as que tratam coletivamente de suas condições legais, sócio-econômicas, políticas, participação em acontecimentos históricos, contribuição à sociedade etc. Obras específicas sobre as condições sociais e status das mulheres, inclusive discussões do ponto de vista histórico, entram em Mulheres - Condições sociais.

Ressalta-se que o VCUSP disponibilizou apenas o descritor História da mulher inserido abaixo do descritor Historiografia. Bias: Salientando apenas a história especificamente da mulher, a linguagem não considera a participação das mulheres na História como um todo, o que, atualmente, não é mais aceito.

Em síntese, percebe-se que a TAFBN está atenta à importância das mulheres na História, principalmente quando especifica os períodos históricos.

\section{Indivíduo}

\begin{tabular}{|c|c|l|c|}
\hline \multicolumn{4}{|c|}{ Semelhantes } \\
\hline \multirow{2}{*}{ Categoria } & \multirow{2}{*}{ Linguagem } & \multicolumn{1}{|c|}{ Descritor } & $\begin{array}{c}\text { Número da } \\
\text { ficha de registro }\end{array}$ \\
\hline \multirow{2}{*}{ Indivíduo } & \multirow{2}{*}{ TAFBN } & Feminilidade & 219 \\
\cline { 3 - 4 } & & Lesbianismo & 212 \\
\cline { 3 - 4 } & & Mulher (Filosofia) & 001 \\
\hline
\end{tabular}




\begin{tabular}{|l|l|l|}
\hline & casadas & 071 \\
\cline { 3 - 3 } & Relações homem-mulher & 218 \\
\cline { 2 - 3 } & Roupas & 204 \\
\cline { 2 - 3 } & Feminilidade (Psicologia) & 010 \\
\cline { 2 - 3 } & Lesbianismo & 035 \\
\cline { 2 - 3 } & Mulher & 015 \\
\cline { 2 - 3 } & casada & 016 \\
\hline \multirow{4}{*}{ VCB } & Feminilidade & 059 \\
\cline { 2 - 3 } & casada & 001 \\
\cline { 2 - 3 } & Relações homem-mulher & 047 \\
\cline { 2 - 3 } & Vestuário & 055 \\
\hline
\end{tabular}

\begin{tabular}{|c|c|c|c|}
\hline \multicolumn{4}{|c|}{ Diferentes } \\
\hline Categoria & Linguagem & Descritor & $\begin{array}{c}\text { Número da } \\
\text { ficha de registro }\end{array}$ \\
\hline \multirow{32}{*}{ Indivíduo } & \multirow{27}{*}{ TAFBN } & Amizade & 209 \\
\hline & & Autoaceitação & 011 \\
\hline & & Autoestima & 006 \\
\hline & & Autorrealização & 012 \\
\hline & & Beleza (Estética) & 203 \\
\hline & & Calvície & 216 \\
\hline & & Defesa pessoal & 024 \\
\hline & & Etiqueta & 202 \\
\hline & & Feminilidade (Filosofia) & 220 \\
\hline & & Grávidas & 113 \\
\hline & & Lésbicas & 116 \\
\hline & & Menopausa & 206 \\
\hline & & $\begin{array}{l}\text { Mulheres (Subdivisão controlada } \\
\text { para serviços militares (não pode } \\
\text { ser subdividido por local) e para } \\
\text { guerras) }\end{array}$ & 244 \\
\hline & & brancas & 069 \\
\hline & & meia-idade & 089 \\
\hline & & divorciadas & 093 \\
\hline & & fatais & 111 \\
\hline & & Identidade & 049 \\
\hline & & idosas & 117 \\
\hline & & índias & 121 \\
\hline & & iranianas de origem americana & 123 \\
\hline & & jovens & 125 \\
\hline & & saaráuis & 186 \\
\hline & & solteiras & 187 \\
\hline & & Negras & 162 \\
\hline & & Personificadores & 213 \\
\hline & & Roupas íntimas & 198 \\
\hline & \multirow{2}{*}{ VCB } & Cônjuge & 013 \\
\hline & & divorciada & 019 \\
\hline & \multirow{3}{*}{ VCUSP } & Estereótipos (Psicologia) & 026 \\
\hline & & Moda & 037 \\
\hline & & Voz & 058 \\
\hline
\end{tabular}


Quando se pensou a mulher enquanto indivíduo, destacaram-se os seguintes aspectos: Mulher como gênero; feminilidade (enquanto uma característica da mulher advinda da Psicologia, que pode também ser uma especificidade relacionada ao sexo); casamento; relações homem-mulher; lesbianismo; vestuário.

Em relação ao descritor Gênero, destaca-se os elementos do VCB:

NÃ̃ USE Identidade de gênero

NÃO USE Identidade sexual

\section{Relação associativa (TR):}

TR Homem

TR Mulher

TR Relações de gênero

Notação de classificação associada: CDD 305.3

Nota de escopo: "Princípio que transforma as diferenças biológicas entre os sexos em desigualdades sociais estruturando a sociedade sobre a assimetria das relações entre homens e mulheres" (Tesauro para estudos de gênero e sobre mulheres / Fundação Carlos Chagas).

Em relação às mulheres homossexuais, na TAFBN o descritor Lesbianismo é UP, entre outros, Homossexualismo feminino e tem como TG Homossexualismo e TG Mulheres Comportamento sexual. No VCB, também há uma relação de equivalência Lesbianismo UP Homossexualismo feminino e tem como TG Homossexualismo. Ressalta-se que os homens homossexuais também são representados dessa maneira. Bias: Utilização do sufixo -ismo (conforme explicação da página 56) e na TAFBN o descritor Lesbianismo está inserido abaixo de Mulheres - Comportamento sexual, o que ressalta apenas o aspecto sexual inerente à realidade das lésbicas.

No VCB o adjetivo masculino aparece apenas relacionado a Homossexualismo.

No VCUSP, a maioria dos conteúdos relacionados à homossexualidade, bem como a cultura e outras áreas com uma epistemologia em construção e com um senso comum muito diversificado encontram-se dentro do campo maior Psicologia, ressaltando, dessa maneira, a representação sob biasses desses conteúdos documentais.

Em relação aos homossexuais, há uma remissiva em seu caráter mais democrático, que direciona: Homossexualismo ver Homossexualidade.

Destaca-se que dos temas abordados pela presente seção, este é o que mais reforça estereótipos sociais, como, por exemplo, o descritor Mulheres fatais UP Mulheres sedutoras (TAFBN). 
Maternidade

\begin{tabular}{|c|c|l|c|}
\hline \multicolumn{2}{|c|}{ Semelhantes } \\
\hline \multirow{3}{*}{ Categoria } & \multirow{2}{*}{ Linguagem } & \multicolumn{1}{c|}{ Descritor } & $\begin{array}{c}\text { Número da } \\
\text { ficha de registro }\end{array}$ \\
\hline \multirow{4}{*}{ Maternidade } & TAFBN & Amor & 242 \\
\cline { 2 - 4 } & \multirow{2}{*}{ VCB } & Aleitamento & 001 \\
\cline { 2 - 4 } & \multirow{2}{*}{ VCUSP } & Mortalidade & 038 \\
\cline { 2 - 4 } & & Aleitamento & 010 \\
\cline { 3 - 4 } & & Amor & 011 \\
\cline { 2 - 4 } & Mortalidade & 038 \\
\hline
\end{tabular}

\begin{tabular}{|c|c|c|c|}
\hline \multicolumn{4}{|c|}{ Diferentes } \\
\hline Categoria & Linguagem & Descritor & $\begin{array}{c}\text { Número da } \\
\text { ficha de registro }\end{array}$ \\
\hline \multirow{12}{*}{ Maternidade } & \multirow{2}{*}{ TAFBN } & Carência & 241 \\
\hline & & Mães (TG: Mulheres) & 243 \\
\hline & \multirow{2}{*}{ VCB } & Leite & 041 \\
\hline & & Nutrição & 039 \\
\hline & \multirow{8}{*}{ VCUSP } & Ausência & 012 \\
\hline & & Comportamento animal & 014 \\
\hline & & Enfermagem materno-infantil & 024 \\
\hline & & Exposição & 027 \\
\hline & & Idade & 033 \\
\hline & & Relações mãe-criança & 015 \\
\hline & & Relações mãe-criança & 043 \\
\hline & & Substitutos do leite humano (UP) & 052 \\
\hline
\end{tabular}

No VCUSP, os termos referentes à gravidez encontram-se representados sem biasses em áreas como: Gravidez; Gravidez de alto risco; Gravidez na adolescência; Gravidez no diabetes, não colocando apenas a mulher como sujeito da concepção e cuidados, como ocorre normalmente. Sobre a maternidade, há também descritores no contexto do Direito Civil (Mães, Ação de investigação de maternidade, Mãe solteira); no contexto da Psicologia Aplicada (Adolescentes, Mães adolescentes). Ressalta-se que essa temática encontra-se mais representada pela figura da mulher uma vez que biologicamente a mãe desempenha papéis que não se estendem aos pais, tais como a gestação e o aleitamento.

\section{Religião}

\begin{tabular}{|c|c|c|c|}
\hline \multicolumn{4}{|c|}{ Semelhantes } \\
\hline Categoria & Linguagem & Descritor & $\begin{array}{c}\text { Número da } \\
\text { ficha de registro }\end{array}$ \\
\hline Religião & TAFBN & & \\
\hline
\end{tabular}




\begin{tabular}{|c|c|c|c|}
\hline \multicolumn{4}{|c|}{ Diferentes } \\
\hline Categoria & Linguagem & Descritor & $\begin{array}{c}\text { Número da } \\
\text { ficha de registro }\end{array}$ \\
\hline \multirow{27}{*}{ Religião } & \multirow{27}{*}{ TAFBN } & Deusas & 211 \\
\hline & & Feminilidade de Deus & 222 \\
\hline & & Judias & 126 \\
\hline & & Muçulmanas & 124 \\
\hline & & (Teologia) & 003 \\
\hline & & (Teologia cristã) & 002 \\
\hline & & adventistas do sétimo dia & 061 \\
\hline & & espiritismo & 099 \\
\hline & & religião & 107 \\
\hline & & Livros de orações e devoções & 051 \\
\hline & & médiuns & 129 \\
\hline & & místicas & 131 \\
\hline & & Mitologia & 052 \\
\hline & & Bíblia & 137 \\
\hline & & Igreja Católica & 143 \\
\hline & & obras da Igreja & 160 \\
\hline & & obras da Igreja - Igreja Católica & 159 \\
\hline & & Budismo & 163 \\
\hline & & clero & 165 \\
\hline & & cristianismo & 166 \\
\hline & & Hinduísmo & 170 \\
\hline & & Islamismo & 171 \\
\hline & & judaísmo & 173 \\
\hline & & protestantes & 183 \\
\hline & & Vida religiosa & 060 \\
\hline & & Ordenação & 196 \\
\hline & & Ordens monásticas e religiosas & 156 \\
\hline
\end{tabular}

Especificidades ligadas a questões religiosas e de Religião foram salientadas apenas pela TAFBN e, apesar de tratar as mulheres como exceções as normas masculinas (OLSON, 2002) e a considerar generalidade como masculinidade (LÓPEZ-HUERTAS PÉREZ; TORRES RAMÍREZ, 2005), mostra-se tão inclusiva quanto se mostrou nos aspectos ligados à História apresentados anteriormente.

Destaca-se apenas que o descritor Mulher (Teologia cristã) da TAFBN, mesmo apresentando a relação hierárquica: TG Homem (Teologia cristã) e TG Mulher (Teologia) apresenta uma bias em sua nota de escopo:

Nota de escopo: Usado para obras que tratam da teologia cristã do sexo feminino. Obras sobre a teologia do gênero humano e de pessoas do sexo masculino, do ponto de vista de duas ou mais religiões entram em Homem (Teologia cristã). Obras sobre a teologia cristã do gênero humano entram em Homem (Teologia). 
Bias: Termos masculinos usados no plural com o conteúdo semântico de homens e mulheres, ou seja, o modo genérico. Ressalta-se que essa nota de escopo salienta uma bias inerente à própria linguagem natural e dessa maneira cumpre a sua real função da nota de escopo (ou nota explicativa, definição) não apenas do termo, mas do discurso que essa linguagem documental utiliza.

Saúde e Esporte

\begin{tabular}{|c|c|c|c|}
\hline \multicolumn{4}{|c|}{ Semelhantes } \\
\hline Categoria & Linguagem & Descritor & $\begin{array}{c}\text { Número da } \\
\text { ficha de registro }\end{array}$ \\
\hline \multirow{21}{*}{ Saúde e Esporte } & \multirow{7}{*}{ TAFBN } & Educação física & 029 \\
\hline & & Esportes & 034 \\
\hline & & Infecundidade & 214 \\
\hline & & alcoólatras & 064 \\
\hline & & Psicologia & 054 \\
\hline & & Saúde e higiene & 042 \\
\hline & & Serviços de saúde & 023 \\
\hline & \multirow{4}{*}{$\mathrm{VCB}$} & Psicologia & 024 \\
\hline & & Saúde & 026 \\
\hline & & Saúde materno-infantil & 040 \\
\hline & & Saúde materno-infantil & 042 \\
\hline & \multirow{10}{*}{ VCUSP } & Educação física & 023 \\
\hline & & Escala de segmento de alccolistas & 025 \\
\hline & & Infertilidade & 035 \\
\hline & & no esporte & 003 \\
\hline & & Psicologia & 045 \\
\hline & & Psicologia & 046 \\
\hline & & Saúde & 048 \\
\hline & & Saúde materno-infantil & 049 \\
\hline & & Serviços de saúde & 050 \\
\hline & & Serviços de saúde & 051 \\
\hline
\end{tabular}

\begin{tabular}{|c|c|c|c|}
\hline \multicolumn{4}{|c|}{ Diferentes } \\
\hline Categoria & Linguagem & Descritor & $\begin{array}{c}\text { Número da } \\
\text { ficha de registro }\end{array}$ \\
\hline \multirow[t]{11}{*}{ Saúde e Esporte } & \multirow[t]{11}{*}{ TAFBN } & Administração do stress & 005 \\
\hline & & AIDS (Doença) & 063 \\
\hline & & Ansiedade & 007 \\
\hline & & Aptidão física & 009 \\
\hline & & Cardiopatias & 074 \\
\hline & & Depressão & 025 \\
\hline & & Doentes mentais & 096 \\
\hline & & Exercícios físicos & 038 \\
\hline & & Futebol & 205 \\
\hline & & $\begin{array}{llll}\begin{array}{l}\text { Hospitais } \\
\text { obstetrícia }\end{array} & \text { de } & \text { ginecologia } & \text { e } \\
\end{array}$ & 048 \\
\hline & & deficientes & 092 \\
\hline
\end{tabular}




\begin{tabular}{|l|l|c|}
\hline \multirow{5}{*}{} & Doenças & 027 \\
\cline { 2 - 3 } & Doenças - Diagnóstico & 028 \\
\cline { 2 - 3 } & psicanálise & 105 \\
\cline { 2 - 3 } & Fisiologia & 039 \\
\cline { 2 - 3 } & HIV - positivo & 114 \\
\cline { 2 - 3 } & idosas - Doenças & 118 \\
\cline { 2 - 3 } & Nutrição & 053 \\
\cline { 2 - 3 } & Saúde mental & 058 \\
\cline { 2 - 3 } & surfistas & 188 \\
\cline { 2 - 3 } & Obesidade & 177 \\
\cline { 2 - 3 } & Parapsicologia & 102 \\
\hline \multirow{5}{*}{ VCB } & & 013 \\
\hline \multirow{5}{*}{ VCUSP } & Centros de saúde materno-infantil & 020 \\
\cline { 2 - 3 } & Doenças dos genitais & 021 \\
\cline { 2 - 3 } & Doenças dos genitais & 030 \\
\cline { 2 - 3 } & Doenças dos genitais & 029 \\
\cline { 2 - 3 } & Ginástica & 034 \\
\cline { 2 - 3 } & Imunidade materno-adquirida & 039 \\
\cline { 2 - 3 } & Neoplasias dos genitais & 040 \\
\cline { 2 - 3 } & Neoplasias dos genitais & \\
\hline
\end{tabular}

Em relação à saúde das mulheres há uma tendência em salientar aspectos relacionados à educação sanitária, sexualidade e maternidade, como demonstra o exemplo a seguir do descritor Saúde da mulher do VCB:

Relação associativa (TR): Aborto; Aleitamento materno; Anticoncepcional; Direitos da mulher; Educação sexual; Gravidez; Higiene sexual; Menopausa; Parto; Planejamento familiar.

Bias: Considerar que o sujeito da anticoncepção é a mulher, bem como salientar aspectos ligados a Educação sanitária, pois não há a necessidade de incluir termos referentes a gênero em descritores como educação sanitária e higiene.

Os aspectos relacionados à Psicologia dizem respeito tanto a Feminilidade (TR no VCB) e a Psicologia aplicada do homem e Psicologia aplicada da mulher (TE no VCUSP), quanto às especificidades não apenas femininas (como demonstra o descritor Mulheres Psicologia da TAFBN):

Relação hierárquica (TG/TE):

TE Animus (Psicanalise)

TE Ansiedade em mulheres

TE Assertividade em mulheres

TE Autoaceitação em mulheres

TE Autoestima em mulheres

TE Autorrealização (Psicologia) em mulheres

TE Autorrealização em mulheres 
TE Motivo de realização em mulheres

TE Mulheres na liderança

Ressalta-se que no exemplo acima há a seguinte relação associativa: TR Mulheres Saúde mental. Bias: Os aspectos apresentados como TE desse descritor não podem ser relacionados à saúde mental, uma vez que esse relacionamento poderia ser feito apenas com aspectos que têm um padrão de normalidade, como os aspectos ligados à saúde do coração, por exemplo.

Em relação ao esporte e à educação física, destaca-se a tentativa da TAFBN de incluir a mulher em algumas especificidades, como futebol, ginástica, modelagem física, treinamento com peso e voo livre.

Em síntese, em relação aos aspectos ligados à saúde e ao esporte há uma tendência em tratar as mulheres como exceções as normas masculinas (OLSON, 2002) e a considerar generalidade como masculinidade (LÓPEZ-HUERTAS PÉREZ; TORRES RAMÍREZ, 2005). Em relação à saúde, acrescenta-se a tendência em designar maior, mas não exclusiva, responsabilidade à mulher no que diz respeito à concepção e anticoncepção.

\section{Sexualidade}

\begin{tabular}{|c|c|c|c|}
\hline \multicolumn{4}{|c|}{ Semelhantes } \\
\hline Categoria & Linguagem & Descritor & $\begin{array}{c}\text { Número da } \\
\text { ficha de registro }\end{array}$ \\
\hline \multirow{13}{*}{ Sexualidade } & CDDireito & & \\
\hline & \multirow{4}{*}{ TAFBN } & Aparelho genital & 210 \\
\hline & & Esterilização & 036 \\
\hline & & Hormônios sexuais & 047 \\
\hline & & Orgasmo & 215 \\
\hline & \multirow{4}{*}{ VCB } & Aparelho genital & 034 \\
\hline & & Aparelho genital & 036 \\
\hline & & $\begin{array}{lll}\begin{array}{l}\text { Esterilização } \\
\text { natalidade) }\end{array} & \text { (controle } & \text { de } \\
\end{array}$ & 009 \\
\hline & & $\begin{array}{lll}\begin{array}{l}\text { Esterilização } \\
\text { natalidade) }\end{array} & \text { (controle } & \text { de } \\
\end{array}$ & 033 \\
\hline & \multirow{4}{*}{ VCUSP } & Dispositivos anticoncepcionais & 019 \\
\hline & & Genitália & 028 \\
\hline & & Hormônios sexuais & 032 \\
\hline & & Orgasmo & 041 \\
\hline
\end{tabular}

\begin{tabular}{|c|c|l|c|}
\hline \multicolumn{4}{|c|}{ Diferentes } \\
\hline \multirow{2}{*}{ Categoria } & Linguagem & \multicolumn{1}{c|}{ Descritor } & $\begin{array}{c}\text { Número da } \\
\text { ficha de registro }\end{array}$ \\
\hline \multirow{2}{*}{ Sexualidade } & CDDireito & Sexo. Condição & 002 \\
\cline { 2 - 4 } & TAFBN & Comportamento sexual & 018 \\
\hline
\end{tabular}




\begin{tabular}{|l|c|l|l|}
\hline & VCB & & \\
\cline { 2 - 3 } & VCUSP & & \\
\hline
\end{tabular}

Em relação à sexualidade, as linguagens inserem descritores referentes aos órgãos genitais femininos e hormônios sexuais, bem como seus correspondentes masculinos, descritores referentes ao orgasmo feminino e descritores referentes à esterilização e anticoncepcionais. Em relação à esterilização, destaca-se o descritor Esterilização (controle de natalidade) do $\mathrm{VCB}$, enquanto um conceito democrático:

\section{Relação de equivalência (UP/USE): \\ Esterilização da mulher \\ Esterilização feminina \\ Relação associativa (TR): \\ TR Controle de natalidade \\ TR Planejamento familiar \\ Relação hierárquica (TG/TE): \\ TG Anticoncepcional}

Em síntese, em relação à sexualidade há uma equidade entre o feminino e o masculino nos descritores das linguagens documentais analisadas. Talvez isso se dê pelo fato de que aspectos ligados à liberdade sexual da mulher, bem como da igual responsabilidade de mulheres e homens em relação à anticoncepção são amplamente discutidos na sociedade. Lembrando que em relação à maternidade e saúde essa equidade ainda não ocorre.

\section{Sociedade}

\begin{tabular}{|c|c|c|c|}
\hline \multicolumn{4}{|c|}{ Semelhantes } \\
\hline \multirow{2}{*}{ Categoria } & Linguagem & Descritor & $\begin{array}{c}\text { Número da } \\
\text { ficha de registro }\end{array}$ \\
\hline \multirow{2}{*}{ Sociedade } & TAFBN & & \\
\cline { 2 - 4 } & VCUSP & & \\
\hline
\end{tabular}

\begin{tabular}{|l|c|l|c|}
\hline \multicolumn{2}{|c|}{ Diferentes } \\
\hline \multirow{2}{*}{ Categoria } & \multirow{2}{|c|}{ Linguagem } & \multicolumn{1}{c|}{ Descritor } & $\begin{array}{c}\text { Número da } \\
\text { ficha de registro }\end{array}$ \\
\hline \multirow{2}{*}{ Sociedade } & \multirow{2}{*}{ TAFBN } & Áreas subdesenvolvidas - do campo & 095 \\
\cline { 3 - 4 } & & Consumidoras & 076 \\
\cline { 3 - 4 } & & Internet & 097 \\
\cline { 3 - 4 } & Antropometria & 008 \\
\cline { 3 - 4 } & & Aspectos sociológicos & 010 \\
\cline { 3 - 4 } & & chefes de família & 072 \\
\hline
\end{tabular}




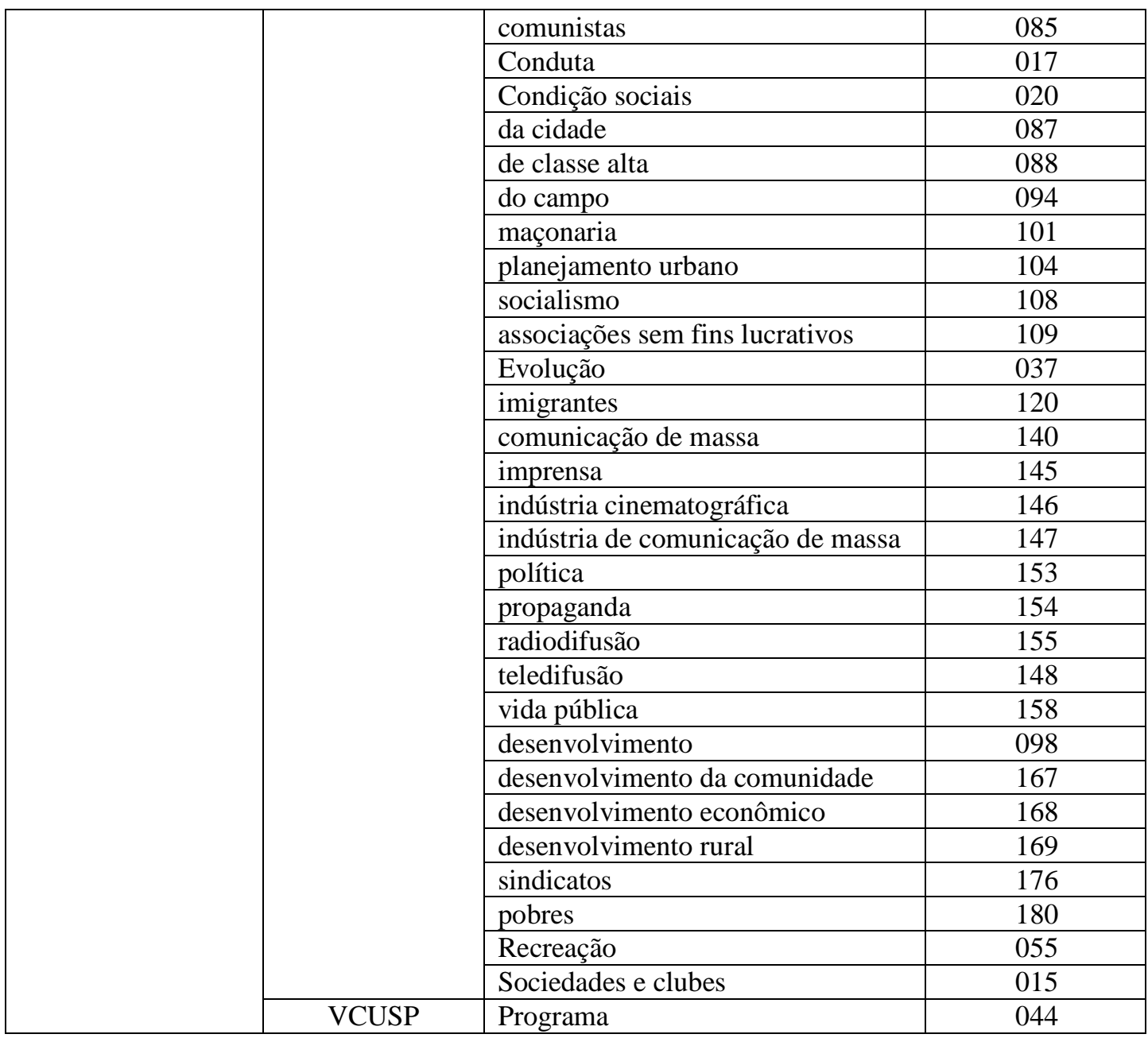

Apenas a TAFBN atentou-se para importantíssimos aspectos sociais das mulheres, que não são equitativos em relação aos homens, mas trazem elementos para a discussão feminina, sendo eles relacionados à classe, desenvolvimentos econômico, rural e de comunidades, bem como relacionados à comunicação e meios de comunicação.

\section{Trabalho}

\begin{tabular}{|c|c|l|c|}
\hline \multicolumn{2}{|c|}{ Semelhantes } \\
\hline \multirow{3}{*}{ Categoria } & \multirow{2}{|c|}{ Linguagem } & \multicolumn{1}{|c|}{ Descritor } & $\begin{array}{c}\text { Número da } \\
\text { ficha de registro }\end{array}$ \\
\hline \multirow{4}{*}{ Trabalho } & CDDireito & & \\
\cline { 2 - 4 } & \multirow{3}{*}{ TAFBN } & jornalistas & 079 \\
\cline { 3 - 4 } & & ciência & 139 \\
\cline { 3 - 4 } & & jornalismo & 172 \\
\cline { 3 - 4 } & Trabalhadoras & 208 \\
\cline { 2 - 4 } & \multirow{2}{*}{ VCB } & Trabalho & 021 \\
\cline { 3 - 4 } & & Trabalho & 028 \\
\hline
\end{tabular}




\begin{tabular}{|l|l|l|c|}
\hline & Trabalho & 029 \\
\cline { 2 - 3 } & \multirow{4}{*}{ VCUSP } & Jornalismo & 036 \\
\cline { 2 - 3 } & ciência & 007 \\
\cline { 2 - 3 } & Trabalho & 008 \\
\cline { 2 - 3 } & Trabalho & 054 \\
\hline
\end{tabular}

\begin{tabular}{|c|c|c|c|}
\hline \multicolumn{4}{|c|}{ Diferentes } \\
\hline Categoria & Linguagem & Descritor & $\begin{array}{c}\text { Número da } \\
\text { ficha de registro }\end{array}$ \\
\hline \multirow[t]{42}{*}{ Trabalho } & CDDireito & Trabalho. Proteção à maternidade & 007 \\
\hline & \multirow[t]{41}{*}{ TAFBN } & Advogadas & 062 \\
\hline & & Arquitetas & 065 \\
\hline & & Aviadoras & 068 \\
\hline & & Compositoras & 084 \\
\hline & & Dramaturgas brasileiras & 070 \\
\hline & & Engenheiras & 110 \\
\hline & & Escritoras & 075 \\
\hline & & Estudantes universitárias & 191 \\
\hline & & Executivas & 133 \\
\hline & & Ferroviárias & 112 \\
\hline & & Filósofas & 077 \\
\hline & & Fotógrafas & 078 \\
\hline & & Legisladoras & 086 \\
\hline & & Médicas & 128 \\
\hline & & artistas & 066 \\
\hline & & atletas & 067 \\
\hline & & cientistas & 073 \\
\hline & & de negócios & 090 \\
\hline & & Emprego & 032 \\
\hline & & intelectuais & 122 \\
\hline & & metalúrgicas & 130 \\
\hline & & militares & 081 \\
\hline & & musicistas & 132 \\
\hline & & aeronáutica & 134 \\
\hline & & agricultura & 135 \\
\hline & & biblioteconomia & 138 \\
\hline & & comunicação & 019 \\
\hline & & medicina & 150 \\
\hline & & tecnologia & 157 \\
\hline & & profissões & 161 \\
\hline & & processamento eletrônico de dados & 174 \\
\hline & & serviço público & 175 \\
\hline & & $\begin{array}{l}\text { reservistas (Subdivisão controlada } \\
\text { para serviços militares) }\end{array}$ & 245 \\
\hline & & pilotos de helicópteros & 178 \\
\hline & & policiais & 082 \\
\hline & & políticas & 181 \\
\hline & & psicanalistas & 184 \\
\hline & & soldados & 080 \\
\hline & & viajantes & 193 \\
\hline & & voluntárias no serviço social & 195 \\
\hline & & Pintoras & 179 \\
\hline
\end{tabular}




\begin{tabular}{|l|l|l|c|}
\hline \multirow{4}{*}{} & Professoras & 083 \\
\cline { 3 - 3 } & Químicas & 185 \\
\cline { 3 - 3 } & Salários & 057 \\
\cline { 3 - 3 } & Trabalhadoras estrangeiras & 119 \\
\cline { 3 - 3 } & Trabalhadoras rurais & 189 \\
\cline { 2 - 3 } & Trabalhadoras têxteis & 190 \\
\cline { 2 - 3 } & Vereadoras & 192 \\
\hline & VCB & & \\
\hline & VCUSP & & \\
\hline
\end{tabular}

Em síntese, quando se fala em mulheres no trabalho ou no mercado de trabalho há uma tendência a considerá-las como exceções as normas masculinas (OLSON, 2002), exceto quando a profissão é tida como tipicamente feminina (p. ex.: aeromoça, bibliotecária, enfermeira etc.) como ocorreu na grande maioria das discussões desta seção.

Em relação ao trabalho das mulheres, destacam-se as relações associativas do descritor Trabalho feminino do $\mathrm{VCB}$, as quais destacam apenas a maternidade:

Relação associativa (TR): Emprego; Gestante; Mercado de trabalho; Mulher; Proteção à maternidade; Salário-maternidade.

Outro aspecto importantíssimo é a presença dos descritores Mulheres na ciência (TAFBN) e Mulheres na ciência (VCUSP); Mulheres jornalistas e Mulheres no jornalismo (TAFBN) e Jornalismo feminino (VCUSP), os quais remontam a discussão de Schiebinger (2001) apresentada a partir da página 72.

A partir dos 108 descritores que encontraram semelhantes em uma ou mais linguagens documentais, apresenta-se o seguinte panorama geral das temáticas abordadas em relação à questão feminina: Criminalidade (CDDireito, VCB, VCUSP - instituições penitenciárias, deliquentes, tráfico de mulheres e violência); Direito (CDDireito, TAFBN, VCB, VCUSP direitos, direito político e voto); Educação (TAFBN, VCB, VCUSP - educação); Feminismo (TAFBN, VCB, VCUSP - feminismo); História (TAFBN, VCUSP - história, história da mulher); Indivíduo (TAFBN, VCB, VCUSP - gênero, feminilidade, casamento, relações homem-mulher, lesbianismo e vestuário); Maternidade (TAFBN, VCB, VCUSP - amor materno, aleitamento e mortalidade); Saúde e Esporte (TAFBN, VCB, VCUSP - educação física, esporte, infecundidade e infertilidade, alcoólatras, psicologia, saúde e higiene, saúde materno-infantil e serviços de saúde); Sexualidade (TAFBN, VCB, VCUSP - aparelho genital, hormônios sexuais, orgasmo e controle de natalidade); Trabalho (TAFBN, VCB, VCUSP - trabalho, mulheres na ciência e no jornalismo). 
Assim, dessas dez temáticas extraídas, houve comunicações entre as seguintes linguagens documentais:

- TAFBN - VCB - VCUSP (termos semelhantes nas temáticas: educação; feminismo; indivíduo; maternidade; saúde e esporte; sexualidade; e trabalho);

- CDDireito - TAFBN - VCB - VCUSP (termos semelhantes na temática: direito);

- CDDireito - VCB - VCUSP (termos semelhantes na temática: criminalidade);

- TAFBN - VCUSP (termos semelhantes na temática: história).

As temáticas Cultura (TAFBN, VCUSP), $\underline{\text { Religião }}$ (TAFBN) e Sociedade (TAFBN, VCUSP) não encontraram descritores semelhantes e exceto duas incidências pertencentes ao VCUSP todas as outras foram extraídas da TAFBN que, enquanto lista de cabeçalhos de assunto, tenta abranger todas as áreas do conhecimento.

Para tanto, e a vista do corpus analisado, confirmam-se as seguintes biasses apresentadas pela literatura: as linguagens documentais tratam as mulheres como exceções as normas masculinas ou omitem essas questões inteiramente (OLSON, 2002).

Todas as linguagens documentais consideram generalidade como masculinidade e utilizam termos masculinos usados no plural com o conteúdo semântico de homens e mulheres, bem como há uma tendência de se criar descritores femininos e omitir seus correspondentes masculinos (LÓPEZ-HUERTAS PÉREZ; TORRES RAMÍREZ, 2005).

Essas biasses apresentadas por López-Huertas Pérez e Torres Ramírez (2005) e confirmadas pela presente pesquisa são o reflexo do sexismo inerente à própria linguagem natural.

Por outro lado, as seguintes possibilidades de biasses apresentadas pela literatura não foram confirmadas pela presente pesquisa: as linguagens documentais isolam as questões da mulher para separá-las do resto do conhecimento (OLSON, 2002), bem como consideram que o sujeito da anticoncepção é a mulher (LÓPEZ-HUERTAS PÉREZ; TORRES RAMÍREZ, 2005). Essas possíveis biasses remontam um preconceito inerente a uma tradição já repensada pelas reflexões atuais, pela literatura científica e por parte do senso comum. 


\section{CONSIDERAÇÕES FINAIS}

No âmbito acadêmico, o profissional da informação encontra-se no início de uma reflexão acerca da dimensão social implícita no processo de representação do conteúdo documental, nos instrumentos que utiliza para tal tarefa e nos substitutos gerados para esse recurso informacional, bem como da presença da influência pessoal e da ausência de neutralidade nesse contexto.

No âmbito da prática profissional, o profissional da informação vem atentando para a necessidade do entendimento da articulação de cada domínio do conhecimento para representá-lo de maneira a que os usuários pertencentes a essa comunidade discursiva sintamse refletidos no sistema de informação a partir de seu catálogo, seus substitutos, sua ordenação dos documentos nas prateleiras ou no ambiente digital, seu atendimento, ou seja, a partir de como esse sistema de informação está demonstrando enxergá-lo.

Mas, ressalta-se que muitas vezes a análise documental e a classificação não são nem ao menos realizadas nas unidades de informação, principalmente nas que utilizam o sistema de catalogação cooperativa a partir da importação de substitutos prontos, as quais realizam, quando muito, a inserção de um termo tópico que melhor represente os interesses de determinada unidade de informação no campo 650 (“Assunto - Termo Tópico”) do registro catalográfico do formato MARC 21 destinado a inserir um termo tópico como entrada secundária de um assunto, pois o substituto, isto é, o registro catalográfico já contém uma entrada principal que não é modificada.

Os mesmos discursos científicos objetos da atuação do profissional da informação “[...] sofrem, em sua apreensão da realidade, o filtro das representações sociais, das imagens tradicionais, dos papéis e lugares designados às pessoas e às coisas, da importância atribuída a certos atos ou a alguns fatos" (NAVARRO-SWAIN, 2004, p. 14). Sendo assim, estão sendo pensados e repensados a partir de valores morais e preconceitos tanto quanto do denominado senso comum.

Então, as denominadas "normalidade" e "universalidade" são impostas ao comportamento humano a partir de uma construção que é moldada por mecanismos de controle social, moral, educacional, religioso e informacional e a partir de perfis préestabelecidos, criando, então, anormalidades, ou seja, preconceitos. 
E no tocante a mulher? O que fazer? Ressaltar as diferenças de gênero podendo com isso reforçá-las e criar "dissabores" onde antes não parecia ter nada de errado ou ignorar essas discussões e deixar que as hierarquias e discriminações continuem dominantes?

Teles (2007) defende que a participação política das mulheres é o caminho mais seguro para se obterem índices mais justos de equidade. Concorda-se com a afirmação e acrescenta-se que na representação do conhecimento deve ocorrer ato semelhante, ou seja, as próprias mulheres devem pensar, repensar e discutir descritores das linguagens documentais que as representem, não apenas como procedimento técnico, mas como uma afirmação de identidade, contra uma representação mimetista dos estereótipos proliferados pela sociedade, pois "A superação da linguagem escravizada constitui processo solidário à liberação do próprio conceito, já que o processo de crítica do mundo social e natural dá-se através de ampliação da consciência apenas possível de ser organizada, processada e expressada linguisticamente" (CARBONI; MAESTRI, 2003, p. 88). Lembrando ainda, que a linguagem documental, enquanto vocabulário controlado, é uma prática social (CINTRA et al, 2002) e perpetua conceitos.

Entende-se que a utilização de linguagens documentais especializadas, ou seja, que amparam domínios do conhecimento específicos não substituirá a utilização das linguagens documentais enciclopédicas ou terminologias de assunto universais utilizadas pela maioria das unidades e sistemas de informação, as quais amparam os domínios do conhecimento a partir de uma dimensão mais ampla em busca de uma padronização e universalidade necessárias para a organização, acesso e recuperação do conhecimento, mas aconselha-se que os profissionais da informação trabalhem com ambas concomitantemente.

Dessa maneira, o profissional da informação colaborará para a concretização dos SORC para uso global, os quais necessitam “[...] incorporar todas as várias bases sintáticas e semânticas de toda e qualquer cultura do mundo e, seus criadores [...] necessitam criar técnicas para a criação policultural da informação" (BEGHTOL, 2002b, p. 45, tradução nossa). Para isso, as biasses na representação do conhecimento devem ser constatadas e prevenidas.

Ressalta-se a necessidade de explicitação de biasses inerentes às linguagens documentais, pois mesmo que essa atitude, talvez, ressalte preconceitos, é extremamente necessária uma vez que não faz parte da missão dos profissionais da informação acomodaremse perante uma situação de discriminação, mesmo sendo esta a materialização de um preconceito presente e, muitas vezes e infelizmente, proliferado pela sociedade. 
Mas, essa democratização da linguagem documental não poderá ser feita a partir da exclusão de biasses e criação de ferramentas idôneas, como sugerem López-Huertas Pérez e Torres Ramírez (2005), pois como foi dito durante todo o trabalho, a linguagem documental reflete a sociedade que a utiliza e modificá-la a partir de uma pretensa exclusão de biasses fará com que a mesma não reflita mais essa sociedade, mas sim uma sociedade ideal a partir da visão de um indivíduo ou grupo, ou seja, a partir da materialização do "politicamente correto".

Para a democratização das linguagens documentais confirmam-se os seguintes mecanismos para prevenção de biasses: inserção de notas que autorizem a utilização do feminino el ou o emprego de descritores sintagmáticos para distinguir o masculino do genérico quando não houver outra opção; e inserção de qualificadores de gênero junto aos descritores, sendo eles “ $(M)$ ” $e$ “(H)”, quando a temática não representar a humanidade em geral (RODRÍGUEZ BRAVO, 2007).

Esses mecanismos de gestão das linguagens documentais somados à reflexão e aplicação de mecanismos como remissivas e termos relacionados explorados em todas as suas potencialidades, criarão e aperfeiçoarão contextos, deixando-os mais inclusivos e equitativos.

Tais mecanismos de gestão das linguagens documentais lhes dão dinamismo e configuram-se viáveis a partir das atuais tecnologias de informação e comunicação e dos ambientes digitais de processamento, armazenamento e recuperação, uma vez que as unidades de informação não realizam a re-indexação ou a re-classificação de seus acervos.

Sendo assim, os profissionais da informação se tornariam mais responsáveis face à ocorrência de biasses na representação do conhecimento a partir da explicitação dos discursos que sua unidade de informação representa, bem como a missão que segue e a comunidade discursiva que pretende incluir em seus produtos. Essa é a premissa de atuação democrática defendida pela presente pesquisa.

Assim, já que a exclusão de todas as biasses ou a inclusão de todos os usuários não é possível a partir da representação do conhecimento pela indexação (estabelecimento de conceitos que representem o conteúdo documental) e pela classificação (estabelecimento de notações de classificação que representem o recurso informacional), as quais utilizam linguagens documentais (ou seja, vocabulários controlados), devem-se utilizar os mecanismos que a Documentação fundamentou, e muito comumente outras áreas utilizam como sendo algo novo, criando, assim, o maior número de pontes informacionais entre um coletivo de informações (produção do conhecimento) e um coletivo de usuários (uso do conhecimento 
registrado e socializado) interagindo em contextos multiculturais, mas ao mesmo tempo sob os pilares construídos e em vias de construção pelos Direitos Humanos.

Finaliza-se com a sinalização de uma ponta de iceberg, qual seja a temática biasses, constatada apenas a partir da percepção de seus efeitos danosos. Ressalta-se que há uma lacuna na literatura da área de OC a esse respeito, sendo assim, clama-se por estudos mais verticalizados no tocante ao mapeamento teórico e conceitual do problema ético das biasses apresentado nesta pesquisa. 


\section{REFERÊNCIAS}

AGUILAR GARCÍA, T. El sistema sexo-género en los movimientos feministas. @mnis: Revue de Civilisation Contemporaine de l'Université de Bretagne Occidentale, 2008. Disponível em: 〈http://www.univ-brest.fr/amnis/documents/Aguilar2008.pdf>. Acesso em: 15 set. 2009.

AUAD, D. Feminismo: que história é essa? Rio de Janeiro: DP\&A, 2003.

AUSTIN, D.; DALE, P. Diretrizes para o estabelecimento e desenvolvimento de tesauros monolíngues. Brasília: IBICT/ SENAI, 1993.

AZERÊDO, S. Preconceito contra a "mulher": Diferença, poemas e corpos. São Paulo: Cortez, 2007. (Preconceitos, 1).

BAIR, S. C. Toward a code of ethics. Technical Services Quarterly, New York, v. 23, n. 1, p. 13-26, 2005.

BARITÉ, M. Organización del conocimiento: un nuevo marco teórico-conceptual en Bibliotecología y Documentación. In: CARRARA, K. (Org.). Educação, universidade e pesquisa. Marília: UNESP; São Paulo: FAPESP, 2001. p. 35-60.

BEGHTOL, C. A proposed ethical warrant for global knowledge representation and organization systems. Journal of Documentation, London, v. 58, n. 5, p. 507-532, 2002a.

BEGHTOL, C. Ethical decision-making for knowledge representation and organization systems for global use. Journal of the American Society for Information Science and Technology, New York, v. 56, n. 9, p. 903-912, 2005.

BEGHTOL, C. Universal concepts, cultural warrant and cultural hospitality. In: LÓPEZHUERTAS, M. J. (Ed.). Challenges in knowledge representation and organization for the $21^{\text {st }}$ century: integration of knowledge across boundaries. Würzburg: ERGON-Verlag, 2002b. p. 45-49. (Advances in Knowledge Organization, 8).

BERMAN, S. Prejudices and antipathies: A Tract on the LC Subject Heads Concerning People. 2. ed. Jeffersin; North Carolina; London: McFarland \& Company, Inc., 1993.

BOOTH, P. F. Indexing: the manual of good practice. Munchen: K. G. Saur, 2001. 
BORKO, H. Information science: what is it? American Documentation, New York, v. 19, n. 1, p. 3-5, 1968.

BRASCHER, M.; CAFÉ, L. Organização da Informação ou Organização do Conhecimento? In: ENCONTRO NACIONAL DE PESQUISA EM CIÊNCIA DA INFORMAÇÃO, 9., 2008, São Paulo. Diversidade cultural e políticas de informação: anais... São Paulo: Universidade de São Paulo, 2008.

BREY, P. The ethics of representation and action in virtual reality. Ethics and Information Technology, Dordrecht, v. 1, n. 1, p. 5-14, 1999.

BUCKLAND, M. K. Information as thing. Journal of the American Society for Information Science, New York, v. 42, n. 5, p. 351-360, 1991.

CARBONI, F.; MAESTRI, M. A linguagem escravizada. São Paulo: Expressão Popular, 2003.

CARO CASTRO, C.; SAN SEGUNDO MANUEL, R. Lenguajes documentales y exclusión social. In: LÓPEZ-HUERTAS, M. J.; FERNÁNDEZ-MOLINA, J. C. (Ed.). La representación y la organización del conocimiento en sus distintas perspectivas: su influencia en la recuperación de la información. Granada: Universidad de Granada, 1999. p. 101-108.

CARVALHO, D. de Q. Classificação Decimal de Direito. 4 ed. rev. e atual. Brasília: Presidência da República, 2002. Disponível em: 〈www.planalto.gov.br〉. Acesso em: 06 junho 2009.

CHAUMIER, J. As técnicas documentais. Lisboa: Publicações Europa-América, 1971. (Ciências Aplicadas, 6).

CINTRA, A. M. M. Estratégias de leitura em documentação. In: SMIT, J. W. (Coord.). Análise documentária: a análise da síntese. 2. ed. Brasília: IBICT, 1987. p. 30-37.

CINTRA, A. M. M. et al. Para entender as linguagens documentárias. 2. ed. rev. e atual. São Paulo: Editora Polis, 2002.

CONSELHO Federal de Biblioteconomia. Código de ética profissional do bibliotecário, 2002. Disponível em: <http://hdl.handle.net/123456789/215>. Acesso em: 17 set. 2009. 
CORTINA, A.; MARTÍNEZ, E. Ética. São Paulo: Edições Loyola, 2005.

CUNHA, I. M. R. F. Análise Documentária. In: SMIT, J. W. (Coord.). Análise documentária: a análise da síntese. 2. ed. Brasília: IBICT, 1987. p. 40-62.

DAHLBERG, I. Ethics and knowledge organization: in memory of Dr. S. R. Ranganathan in his centenary year. International Classification, Frankfurt, v. 19, n. 1, p. 1-2, 1992.

DAHLBERG, I. Feature. Interview with Ingetraut Dahlberg. December 2007. Knowledge Organization, Würzburg, v. 35, n. 2/3, p. 82-85, 2008.

DAHLBERG, I. Knowledge organization: its scope and possibilities. Knowledge Organization, Würzburg, v. 20, n. 4, p. 211-222, 1993.

DIAS, E. W.; NAVES, M. M. L.; MOURA, M. A. O usuário pesquisador e a análise de assunto. Perspectivas em Ciência da Informação, Belo Horizonte, v. 6, n. 2, p. 205-221, 2001.

EMENTA da linha "Produção e Organização da Informação" da Faculdade de Filosofia e Ciências, UNESP, Campus de Marília. Disponível em:

$\langle$ http://www.marilia.unesp.br/index.php?CodigoMenu=363\&CodigoOpcao=366>. Acesso em: 03 julho 2009.

ESTEBAN NAVARRO, M. A.; GARCÍA MARCO, F. J. Las "primeras jornadas sobre organización del conocimiento: organización del conocimiento e información científica". Scire, Zaragoza, v. 4, p. 149-157, 1995.

ESTEBAN NAVARRO, M. A. Principios, reglas y técnica para la gestión del vocabulario y la estructura de los lenguajes documentales. In: GARCÍA MARCO, F. J. (Ed.). Organización del conocimiento en sistemas de información y documentación. Zaragoza: Universidad de Zaragoza, 1997. p. 127-147.

FEINBERG, M. Hidden bias to responsible bias: an approach to information systems based os Haraway's situated knowledges. Information Research, Sweden, v. 12, n. 4, 2007.

FERNÁNDEZ-MOLINA, J. C. et al. Aspectos éticos de las nuevas tecnologías de la información y la comunicación y su reflejo en la organización del conocimiento. In: GASCÓN, J.; BURGUILLOS, F.; PONS, A. (Org.). La dimensión humana de la organización del conocimiento. Barcelona: Universitat de Barcelona, 2005. p. 177-186. 
FERNÁNDEZ-MOLINA, J. C.; GUIMARÃES, J. A. C. Ethical aspects of knowledge organization and representation in the digital environment: their articulation in profesional codes of ethics. In: LÓPEZ-HUERTAS, M. J. (Ed.). Challenges in knowledge representation and organization for the $21^{\text {st }}$ century: integration of knowledge across boundaries. Würzburg: ERGON Verlag, 2002. p. 487-492. (Advances in Knowledge Organization, 8).

FERREIRA, A. B. de H. Novo Aurélio Século XXI: o dicionário da língua portuguesa. 3. ed. rev. e ampl. Rio de Janeiro: Nova Fronteira, 1999.

FREIRE, P. Pedagogia da autonomia: saberes necessários à prática educativa. São Paulo: Paz e Terra, 1996. (Leitura).

FROEHLICH, T. J. Ethical concerns of information professionals in an international context. In: ALVAREZ-OSSORIO, J. R.; GOEDGEBUURE, B. G. (Ed.). New worlds in information and documentation. Amsterdan: Elsevier; FID, 1994. p. 459-470.

GARCÍA GUTIÉRREZ, A. Knowledge organization from a "culture of the border" towards a transcultural ethics of mediation. In: LÓPEZ-HUERTAS, M. J. (Ed.). Challenges in knowledge representation and organization for the $21^{\text {st }}$ century: integration of knowledge across boundaries. Würzburg: ERGON Verlag, 2002. p. 516-522. (Advances in Knowledge Organization, 8).

GIL URDICIAIN, B. Manual de lenguajes documentales. 2. ed. rev. ampl. Gijón: Ediciones Trea, S. L., 2004.

GORMAN, M. Our enduring values: librarianship in the $21^{\text {st }}$ century. Chicago; London: ALA, 2000.

GUIMARÃES, J. A. C. A dimensão teórica do tratamento temático da informação (TTI) no universo científico da International Society for Knowledge Organization - ISKO. Marília: UNESP, 2006a. Projeto de Produtividade em Pesquisa apresentado ao CNPq referente ao período: mar. 2007-fev. 2010.

GUIMARÃES, J. A. C. Aspectos éticos do tratamento temático da informação (TTI): elementos para sua caracterização a partir da interface das dimensões profissional, pedagógica e investigativa na área da Biblioteconomia no Mercosul. Marília: UNESP, 2003. Projeto Integrado de Pesquisa apresentado ao CNPq referente ao período: 2003-2006.

GUIMARÃES, J. A. C. Aspectos éticos do tratamento temático da informação (TTI):

elementos para sua caracterização a partir da interface das dimensões profissional, pedagógica 
e investigativa na área de Biblioteconomia no Mercosul. Marília: UNESP, 2007. Relatório de Produtividade do Projeto Integrado de Pesquisa referente ao período 2003-2006 apresentado ao CNPq.

GUIMARÃES, J. A. C. Aspectos éticos em organização e representação do conhecimento (ORC): uma reflexão preliminar. In: GONZÁLEZ DE GÓMEZ, M. N.; ORRICO, E. G. D. (Org.). Políticas de memória e informação: reflexos na organização do conhecimento. Natal: EDUFRN, 2006b. p. 237-264.

GUIMARAES, J. A. C. As políticas de indexação como elementos para a gestão do conhecimento nas organizações. In: VIDOTTI, S. A. B. G. (Org.). Tecnologia e conteúdos informacionais. São Paulo: Polis, 2004. p. 43-52.

GUIMARÃES, J. A. C. Ciência da informação, arquivologia e biblioteconomia: em busca do necessário diálogo entre o universo teórico e os fazeres profissionais. In: GUIMARÃES, J. A. C.; FUJITA, M. S. L. (Org.). Ensino e Pesquisa em Biblioteconomia no Brasil: a emergência de um novo olhar. Marília: Fundepe; São Paulo: Cultura Acadêmica Editora, 2008. p. 33-43.

GUIMARÃES, J. A. C. et al. Aspectos éticos en organización y representación del conocimiento: un análisis de la bibliografia científica en busca de una categorización preliminar de valores. In: GASCÓN, J.; BURGUILLOS, F.; PONS, A. (Org.). La dimensión humana de la organización del conocimiento. Barcelona: Universitat de Barcelona, 2005. p. 278-285.

GUIMARÃES, J. A. C. et al. Ethics in the Knowledge Organization Environment: an overview of values and problems in the LIS literature. In: ARSENAULT, C.; TENNIS, J. T. (Ed.). Cultural and Identity in Knowledge Organization. Würzburg: ERGON Verlag, 2008. p. 340-346. (Advances in Knowledge Organization, 11).

GUIMARAES, J. A. C.; FERNÁNDEZ-MOLINA, J. C. Los aspectos éticos de la organización y representación del conocimiento en la revista Knowledge Organization. In: FRÍAS, J. A.; TRAVIESO, C. (Org.). Tendencias de investigación en organización del conocimiento. Salamanca: Universidad de Salamanca, 2003. p. 809-816.

GUIMARÃES, J. A. C.; MORAES, J. B. E.; NASCIMENTO, L. M. B. do. A diplomática como perspectiva metodológica para o tratamento de conteúdo de documentos técnicos. In: VALENTIM, M. L. P. (Org.). Métodos qualitativos de pesquisa em ciência da informação. São Paulo: Polis, 2005. p. 135-160. 
GUIMARÃES, J. A. C. O profissional da informação sob o prisma de sua formação. In: VALENTIM, M. L. P. (Ed.). Profissionais da Informação: formação, perfil e atuação profissional. São Paulo: Polis, 2000a. p. 53-70.

GUIMARÃES, J. A. C. Perspectivas de ensino e pesquisa em organização do conhecimento em cursos de biblioteconomia do Mercosul: uma reflexão. In: ENCUENTRO DE EDIBCIC, 5., Granada. La formación de profisionales y investigadores de la formación para la sociedad del conocimiento: actas. Granada: Universidad de Granada, 2000b. p. 206-216.

HJØRLAND, B. Deliberate Bias in Knowledge Organization? In: ARSENAULT, C.; TENNIS, J. T. (Ed.). Cultural and Identity in Knowledge Organization. Würzburg: ERGON Verlag, 2008a. p. 256-260. (Advances in Knowledge Organization, 11).

HJØRLAND, B. Domain analysis in information science: Eleven approaches traditional as well as innovative. Journal of Documentation, London, v. 58, n. 4, p. 422-462, 2002.

HJØRLAND, B. Fundamentals of knowledge organization. Knowledge Organization, Würzburg, v. 30, n. 2, p. 87-111, 2003.

HJØRLAND, B. What is knowledge organization (KO)? Knowledge Organization, Würzburg, v. 35, n. 2/3, p. 86-101, 2008 b.

HUDON, M. Multilingual thesaurus construction: integrating the views of different cultures in one gateway to knowledge and concepts. Knowledge Organization, Würzburg, v. 24, n. 2 , p. 84-91, 1997.

HUNT, L. A invenção dos direitos humanos; Uma história. São Paulo: Companhia das Letras, 2009.

KNOWLEDGE ORGANIZATION: international journal devoted to concept theory, classification, indexing, and knowledge representation, Würzburg, v. 35, n. 2/3, 2008.

KOEHLER, W.; PEMBERTON, J. M. A search for core values: towards a model code of ethics for information professionals. Journal of Information Ethics, Jefferson, v. 9, n. 1, p. 26-54, 2000.

LCSH - Library of Congress Subject Headings. Disponível em:

<http://www.loc.gov/cds/lcsh.html\#lcsh20>. Acesso em: 08 jan. 2009. 
LÓPEZ-HUERTAS, M. J. Análisis del dominio interdisciplinar para la representación y organización del conocimiento. In: GONZÁLEZ DE GÓMEZ, M. N.; ORRICO, E. G. D. (Org.). Políticas de memória e informação: reflexos na organização do conhecimento. Natal: EDUFRN, 2006. p. 209-235.

LÓPEZ-HUERTAS, M. J.; BARITÉ ROQUETA, M. -G. Knowledge representation and organization of gender studies on the Internet: towards integration. In: LÓPEZ-HUERTAS, M. J. (Ed.). Challenges in knowledge representation and organization for the $21^{\text {st }}$ century: integration of knowledge across boundaries. Würzburg: ERGON Verlag, 2002. p. 393-403. (Advances in Knowledge Organization, 8).

LÓPEZ-HUERTAS, M. J. Cultural impact on Knowledge Representation and Organization in a Subject Domain. In: ARSENAULT, C.; TENNIS, J. T. (Ed.). Cultural and Identity in Knowledge Organization. Würzburg: ERGON Verlag, 2008a. p. 340-346. (Advances in Knowledge Organization, 11).

LÓPEZ-HUERTAS, M. J. Some current research questions in the field of knowledge organization. Knowledge Organization, Würzburg, v. 35, n. 2/3, p. 113-136, 2008b.

LÓPEZ-HUERTAS, M. J.; TORRES, I.; BARITÉ, M. Terminological representation of specialized areas in conceptual structures: the case of gender studies. In: MCILWAINE, I. (Ed.). Knowledge organization and the global information society. Würzburg: ERGON Verlag, 2004. p. 35-39. (Advances in Knowledge Organization, 9).

LÓPEZ-HUERTAS PÉREZ, M. J.; TORRES RAMÍREZ, I. de. Terminología de género. Sesgos, interrogantes, posibles respuestas. Datagramazero: Revista de Ciência da Informação, Rio de Janeiro, v. 6, n. 5, 2005.

MCILWAINE, I. C.; MITCHELL, J. S. Preface to especial issue. "What is knowledge organization". Knowledge Organization, Würzburg, v. 35, n. 2/3, p. 79-81, 2008.

MEADOW, C. T. et al. Text Information Retrieval Systems. 3. ed. London: Elsevier, 2007.

MILANI, S. O. Aspectos éticos em organização e representação do conhecimento (ORC): uma análise preliminar de valores e problemas a partir da literatura internacional da área. 2007. 115 f. Trabalho de Conclusão de Curso (Graduação em Biblioteconomia) - Faculdade de Filosofia e Ciências, Universidade Estadual Paulista, Marília, 2007.

MILANI, S. O. Aspectos éticos em organização e representação do conhecimento (ORC): uma análise preliminar de valores e problemas a partir do Journal of the American Society for Information Science and Technology - JASIST e do Journal of Documentation (1995-2004). 
Marília: UNESP, 2006. Relatório final de Iniciação Científica apresentado à FAPESP referente ao período: out. 2005-set. 2006.

MILANI, S. O. et al. Os desvios na representação do conhecimento em um contexto multicultural: abordagens teóricas. In: ROMERO, N. L. (Ed.). Nuevas perspectivas para la difusión y organización del conocimiento. Valencia: Universidad Politécnica de Valencia, 2009. p. 180-190.

MORÁN SUÁREZ, M. A.; RODRÍGUEZ BRAVO, B. La imagen de la mujer en la clasificación decimal universal (CDU). In: EXTREMEÑO PLACER, A. (Ed.). La representación y Organización del Conocimiento: metodologías, modelos e aplicaciones. Alcalá de Henares: Universidad de Alcalá, 2001. 1 CD-ROM.

NAVARRO-SWAIN, T. O que é lesbianismo. São Paulo: Brasiliense, 2004. (Primeiros Passos, 313).

OLSON, H. A. Mapping beyond dewey's boundaries: constructing classificatory space for marginalized knowledge domains (Dewey Decimal Classification excludes some groups). Library Trends, Champaign, v. 47, n. 2, p. 233-254, 1998.

OLSON, H. A. The power to name: locating the limits or subject representation in libraries. Dordrecht: Kluwer Academic Publisher, 2002.

OLSON, H. A. Transgressive deconstructions: feminist/ postcolonial methodology for research in Knowledge Organization. In: FRÍAS, J. A.; TRAVIESO, C. (Org.). Tendencias de investigación en organización del conocimiento. Salamanca: Universidad de Salamanca, 2003. p. 731-740.

ORLANDI, E. P. Discurso e Texto: Formulação e Circulação dos Sentidos. 3. ed. Campinas: Pontes, 2008.

PINHO, F. A. Aspectos éticos em representação do conhecimento: em busca do diálogo entre Antonio García Gutiérrez, Michèle Hudon e Clare Beghtol. 2006. 123 f. Dissertação (Mestrado em Ciência da Informação) - Faculdade de Filosofia e Ciências, Universidade Estadual Paulista, Marília, 2006.

PINTO MOLINA, M. Interdisciplinary approaches to the concept and practice of written text documentary content analysis (WTDCA). Journal of Documentation, London, v. 50, n. 2, p. 111-133, 1994. 
RAFFERTY, P. The representation of knowledge in library classification schemes.

Knowledge Organization, Würzburg, v. 28, n. 4, 2001.

RODRÍGUEZ BRAVO, B. La integració de la dona en els llenguatges documentals: una utopia necessària. BiD: textos universitaris de biblioteconomia i documentació, Barcelona, $\mathrm{n}$. 18, 2007. Disponível em:

<http://www2.ub.edu/bid/consulta_articulos.php?fichero=18rodri1.htm>. Acesso em: 24 jun. 2009.

RODRÍGUEZ BRAVO, B. The Visibility of Women in Indexing Languages. In: BUDIN, G.; SWERTZ, C.; MITGUTSCH, K. (Ed.). Knowledge Organization for a Global Learning Society. Würzburg: ERGON Verlag, 2006. (Advances in Knowledge Organization, 10). p. 413-422.

SANTOS, B. de S. A crítica da razão indolente: Contra o desperdício da experiência. 7. ed. São Paulo: Cortez, 2009. (Para um novo senso comum: a ciência, o direito e a política na transição paradigmática, 1).

SANTOS, B. de S. Para uma concepção multicultural dos direitos humanos. Contexto Internacional, Rio de Janeiro, v. 23, n. 1, p. 7-34, 2001.

SANTOS, T. M.; MADINA, A. M.; SERRA, R. S. CDU: perspectiva de género y discriminación de minorías. In: GARCÍA MARCO, F. J. (Ed.). Organización del conocimiento en sistemas de información: actas del III Encuentro de ISKO - España. Zaragoza: Universidad de Zaragoza, 1999. p. 103-118.

SARACEVIC, T. Ciência da Informação: origem, evolução e relações. Perspectivas em Ciência da Informação, Belo Horizonte, v. 1, n. 1, p. 41-62, 1996.

SCHIEBINGER, L. O feminismo mudou a ciência? Bauru: EDUSC, 2001. (Mulher).

SEMPRINI, A. Multiculturalismo. Bauru: EDUSC, 1999. (Verbum).

SMIT, J. W.; BARRETO, A. de A. Ciência da informação: base conceitual para a formação do profissional. In: VALENTIM, M. L. P. (Org.). Formação do profissional da informação. São Paulo: Polis, 2002. p. 9-23.

SMIT, J. W. Eu, bibliotecário, RG XXXXX e CPF YYYYY, trabalho em arquivo ou museu... algum problema? Palavra-chave, São Paulo, v. 8, p. 12-13, 1994. 
SMIT, J. W. O que é documentação. 2. ed. São Paulo: Brasiliense, 1987.

STRAIOTO, A. C.; GUIMARÃES, J. A. C. A abordagem facetada no contexto da organização do conhecimento: elementos históricos. Páginas a\&b (arquivos \& bibliotecas), Lisboa, n. 14, p. 109-136, 2004.

TAFBN - Terminologia de Assuntos da Fundação Biblioteca Nacional. Disponível em: <http://www.bn.br/portal/?plugin=Isbn\&url=http://catalogos.bn.br/scripts/odwp012k.dll?IND EXLIST=assuntos_pr:assuntos\&tit=Terminologia\%20de\%20Assuntos $>$. Acesso em: 07 jan. 2008.

TELES, M. A. de A. O que são direitos humanos das mulheres. São Paulo: Brasiliense, 2007. (Primeiros Passos, 321).

VAAGAN, R. A. The ethics of librarianship: an international survey. Munchen: K. G. Saur, 2002.

VAN DER WALT, M. S. Round-table: Ethics in knowledge representation and organization. In: LÓPEZ-HUERTAS, M. J. (Ed.). Challenges in knowledge representation and organization for the $21^{\text {st }}$ century: integration of knowledge across boundaries. Würzburg: ERGON Verlag, 2002. (Advances in Knowledge Organization, 8).

VCB - Vocabulário Controlado Básico. Brasília: Biblioteca Acadêmico Luiz Viana Filho, 2007. (Edições da Biblioteca do Senado Federal, 2). 1 CD-ROM. Disponível em: <http://www.senado.gov.br/sf/biblioteca/RVBI/publicacoes.asp>. Acesso em: 09 jan. 2008.

VCUSP - Vocabulário Controlado da Universidade de São Paulo. Disponível em: <http://143.107.73.99/Vocab/Sibix652.dll>. Acesso em: 06 jan. 2008.

VERGUEIRO, W. C. S. Ética profissional versus ética social: uma abordagem sobre os mitos da biblioteconomia. Palavra-chave, São Paulo, v. 8, p. 8-11, 1994.

VIEIRA JUNIOR, N. C. Uso de informação como forma de amenizar os preconceitos acerca da homossexualidade. Londrina. 2005. 55 f. Trabalho de Conclusão de Curso (Graduação em Biblioteconomia) - Universidade Estadual de Londrina, Londrina, 2005. 
$\stackrel{9}{9}$

\begin{tabular}{|c|c|c|}
\hline 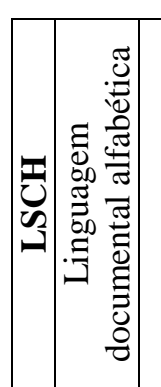 & 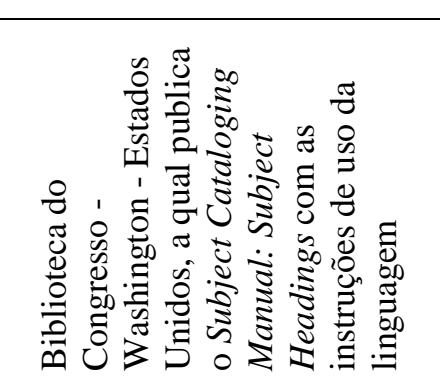 & 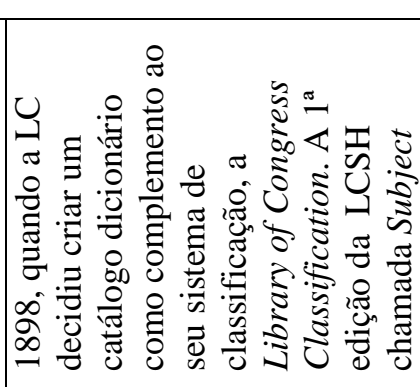 \\
\hline 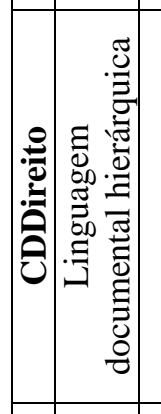 & 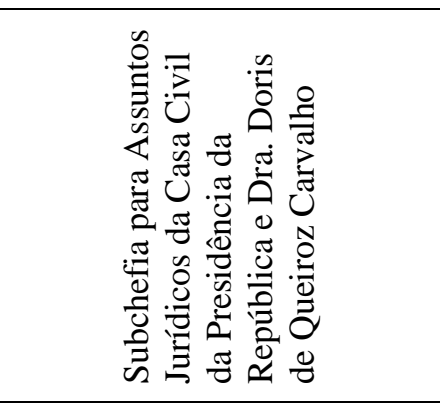 & 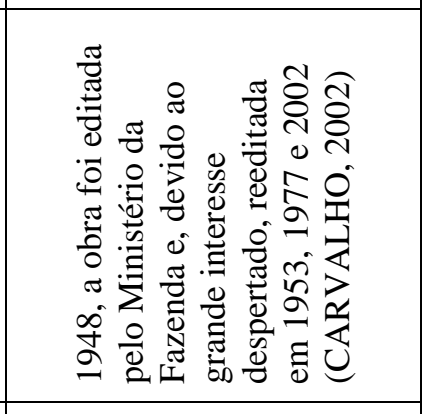 \\
\hline 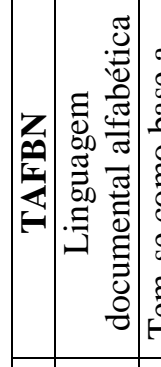 & 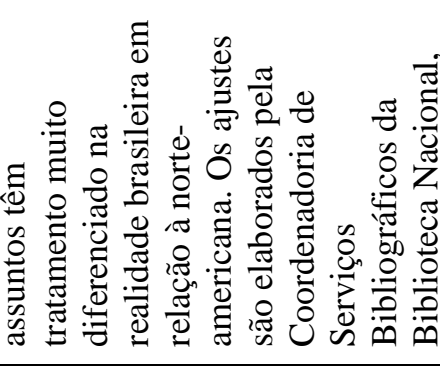 & 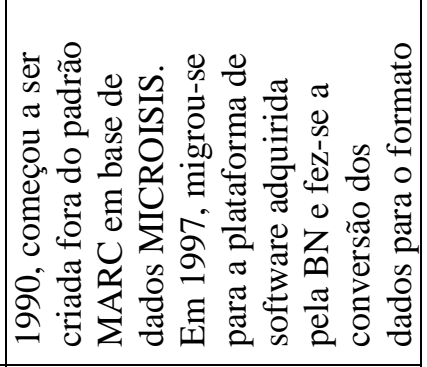 \\
\hline 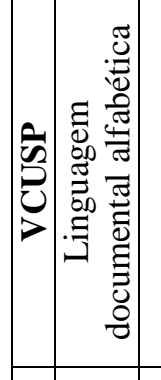 & 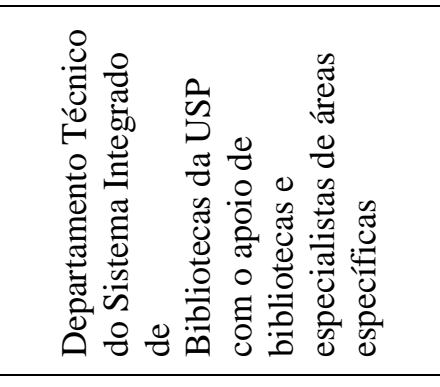 & 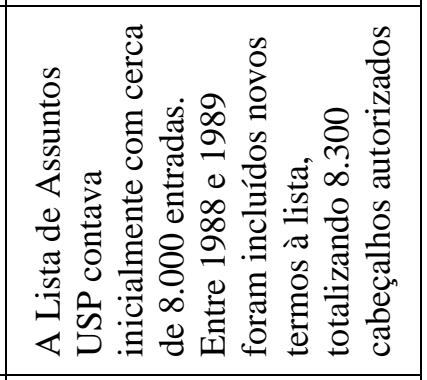 \\
\hline 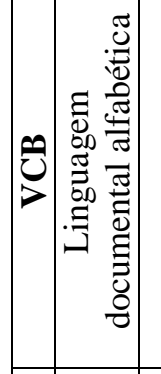 & 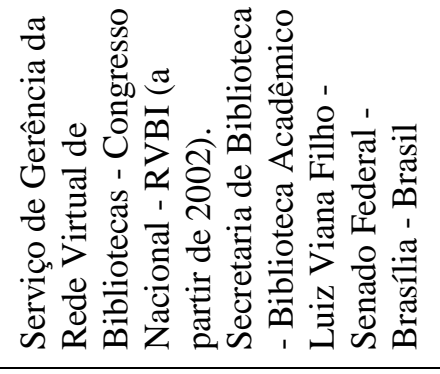 & 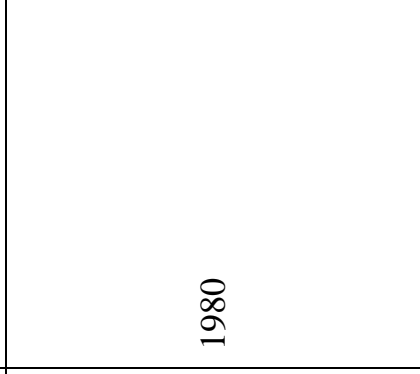 \\
\hline 童 & & 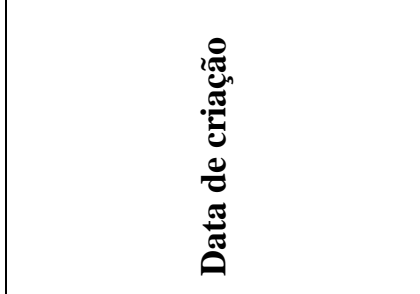 \\
\hline
\end{tabular}


$\bar{n}$

\begin{tabular}{|c|c|}
\hline 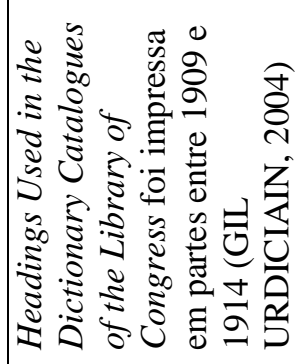 & 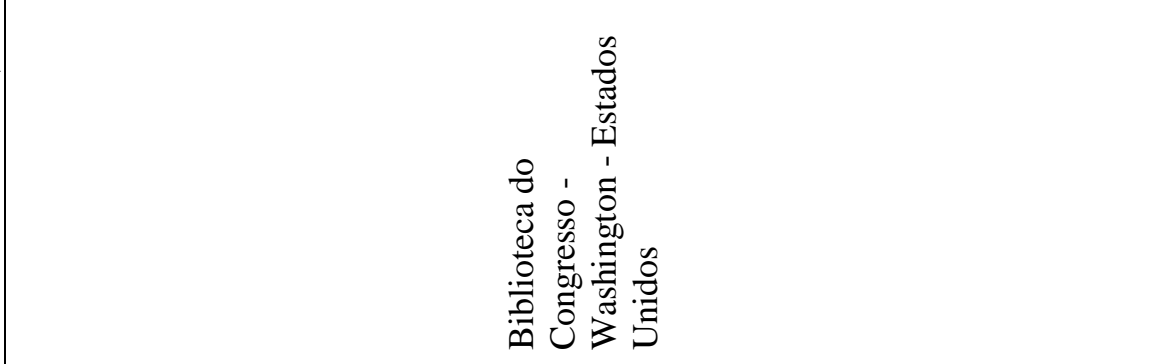 \\
\hline & 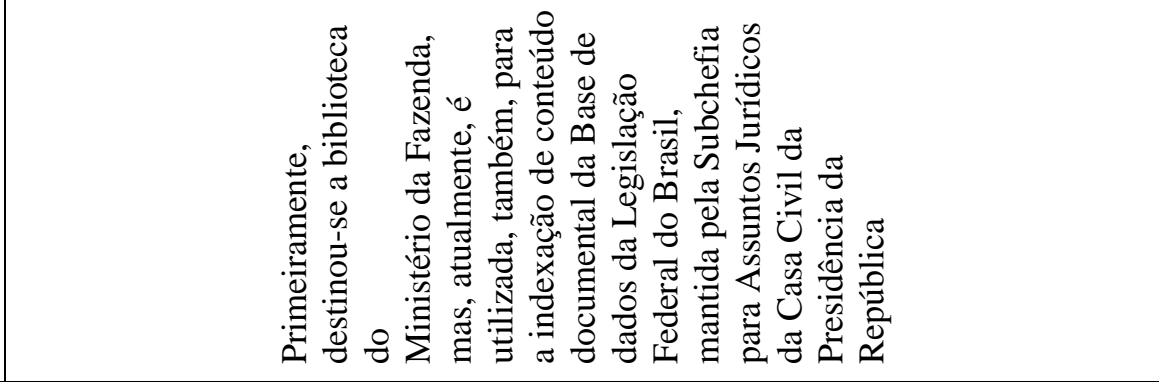 \\
\hline$\frac{x}{\Sigma}$ & 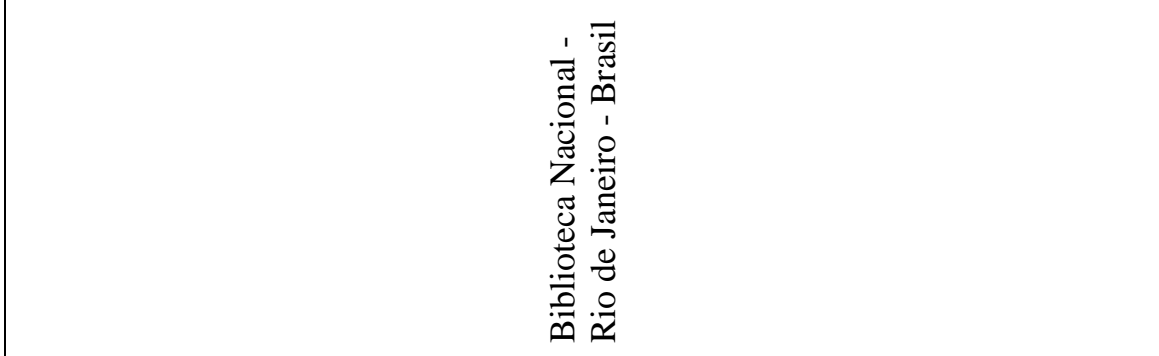 \\
\hline & 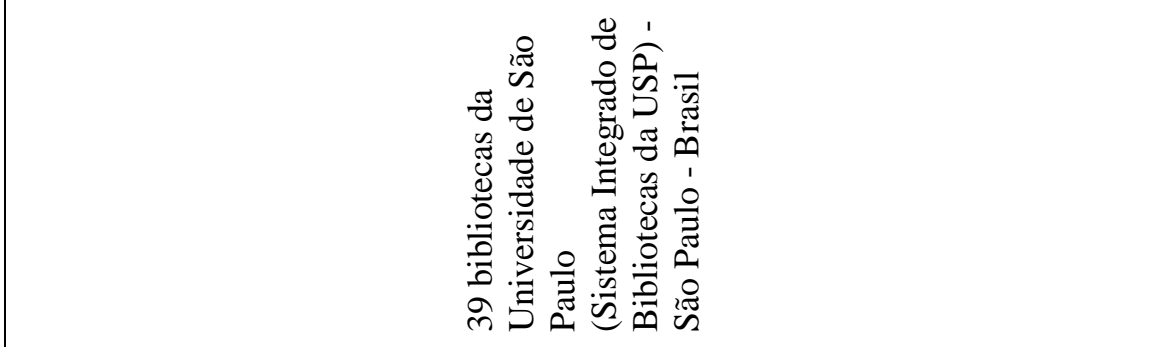 \\
\hline & 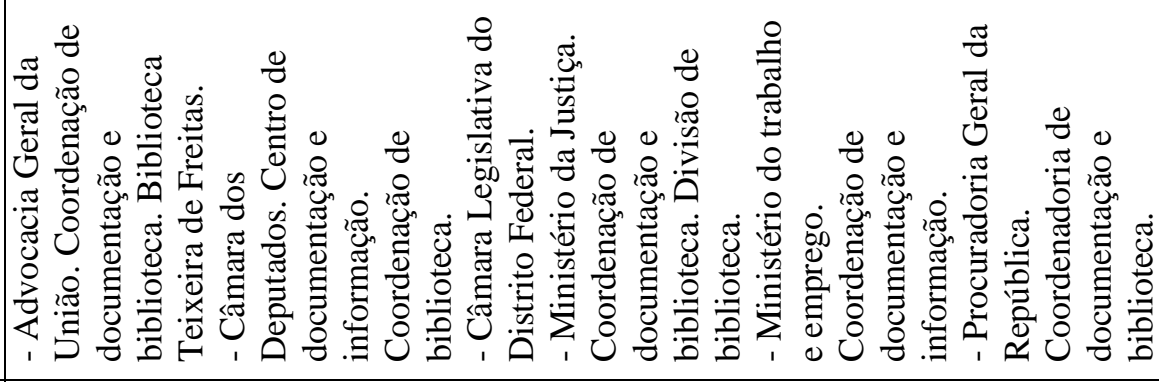 \\
\hline & 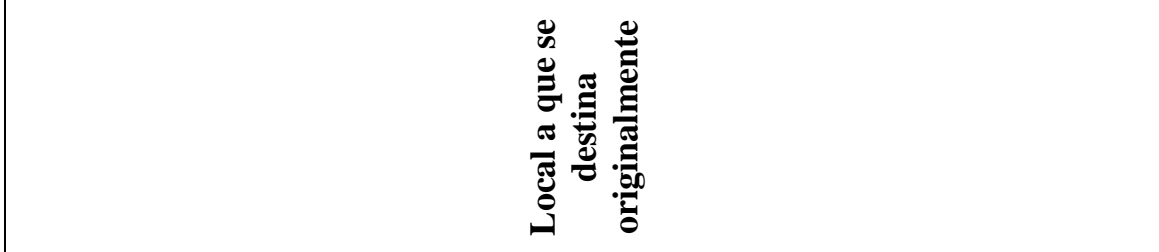 \\
\hline
\end{tabular}




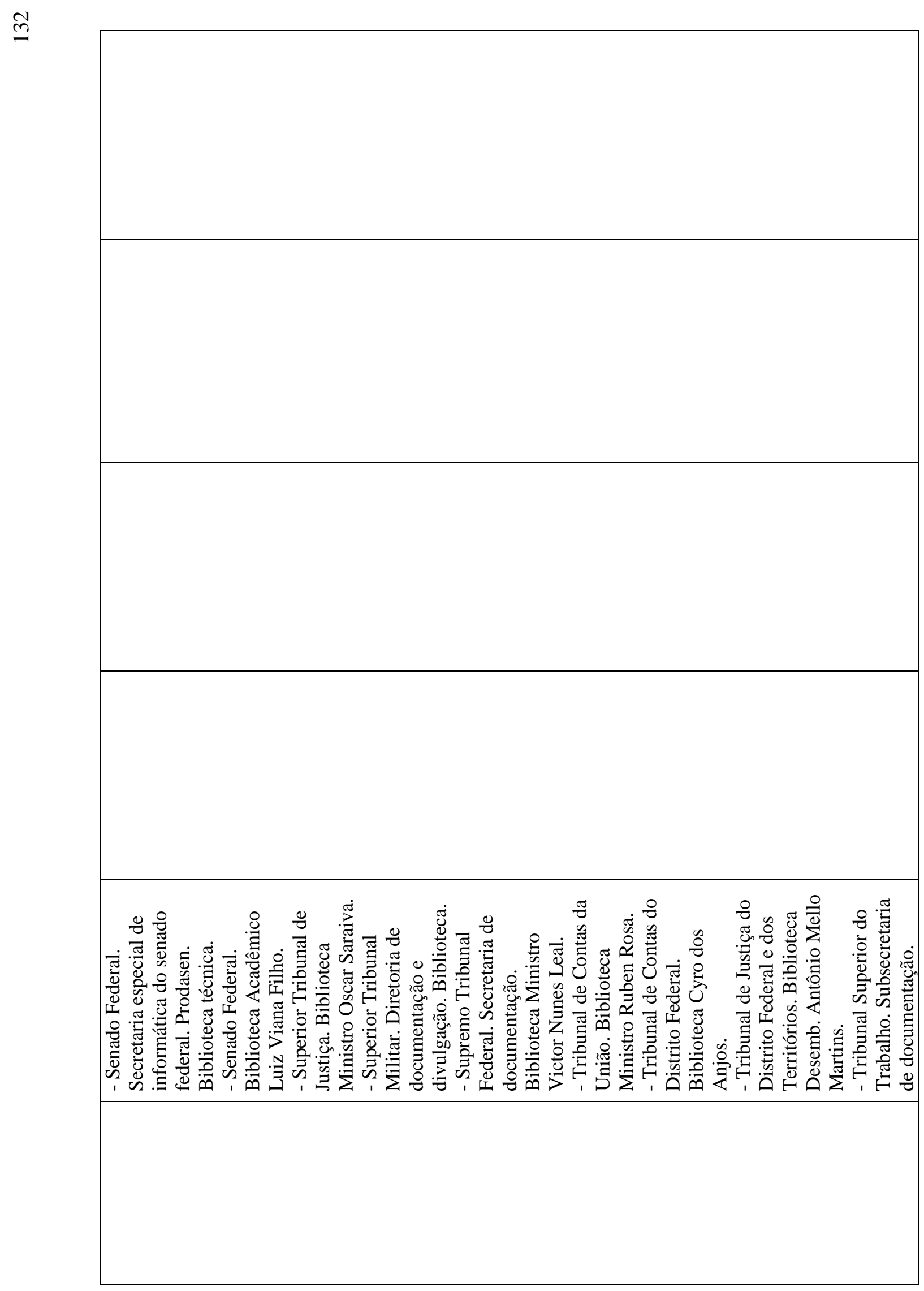




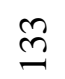

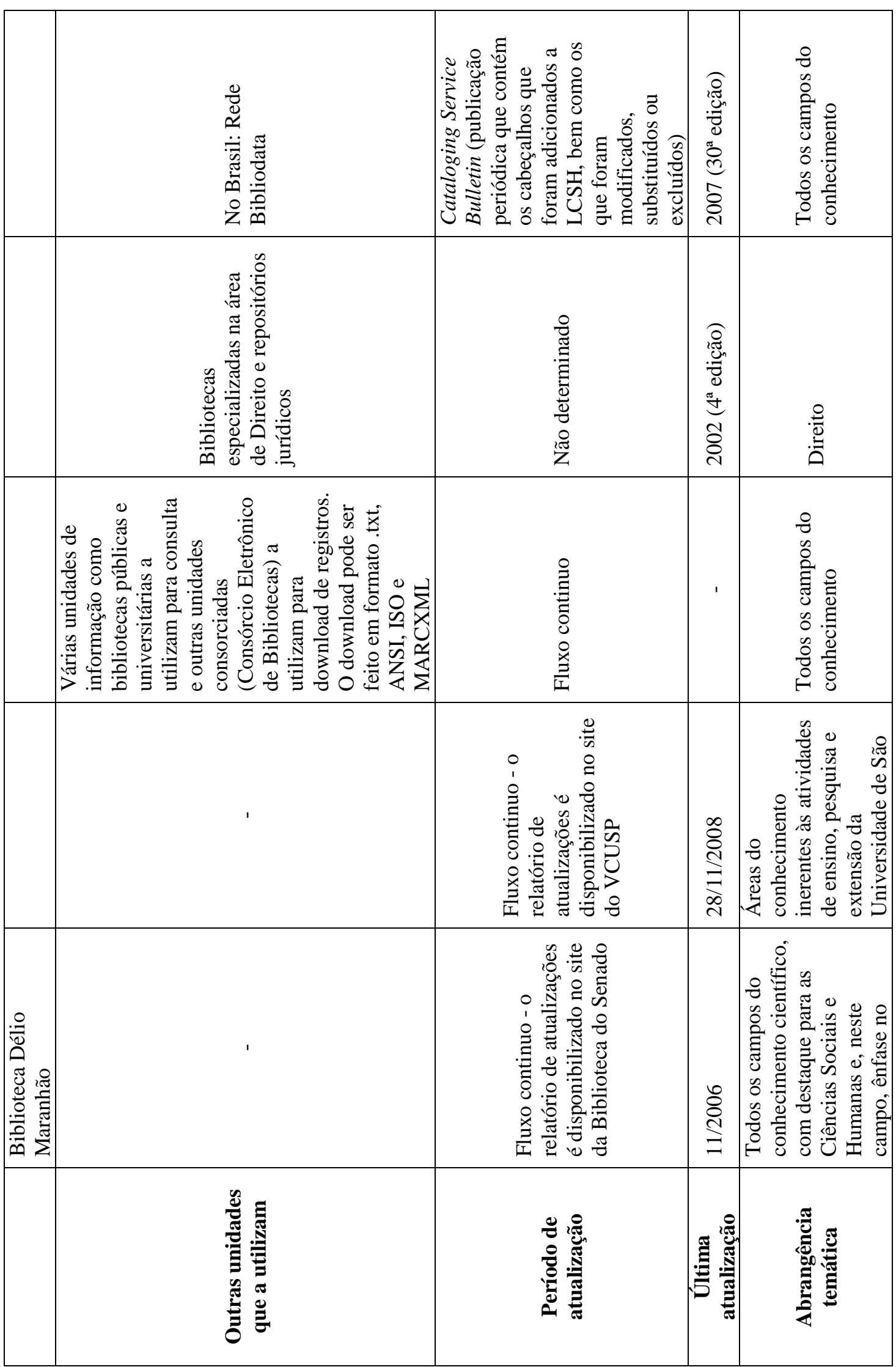


声

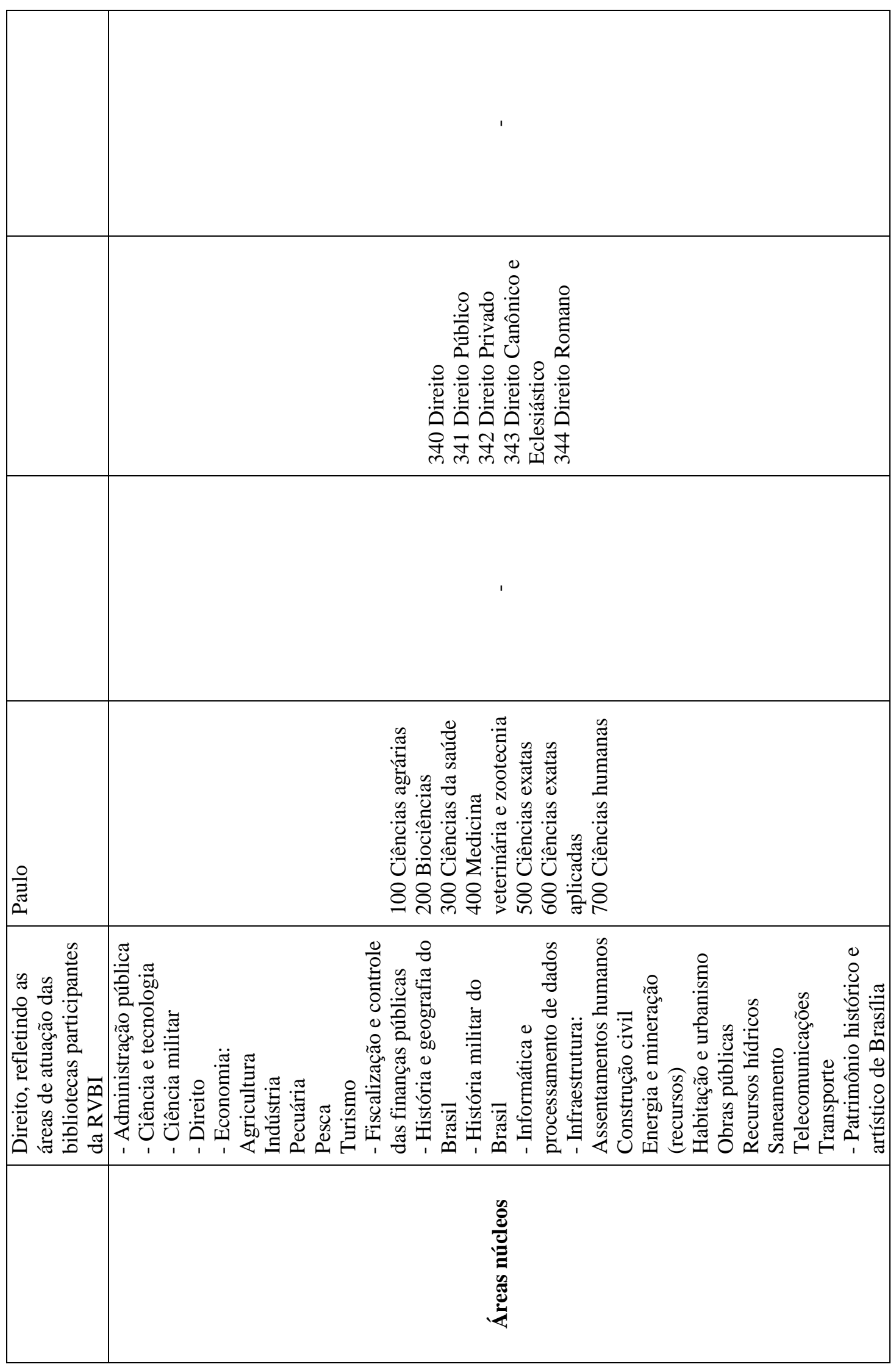




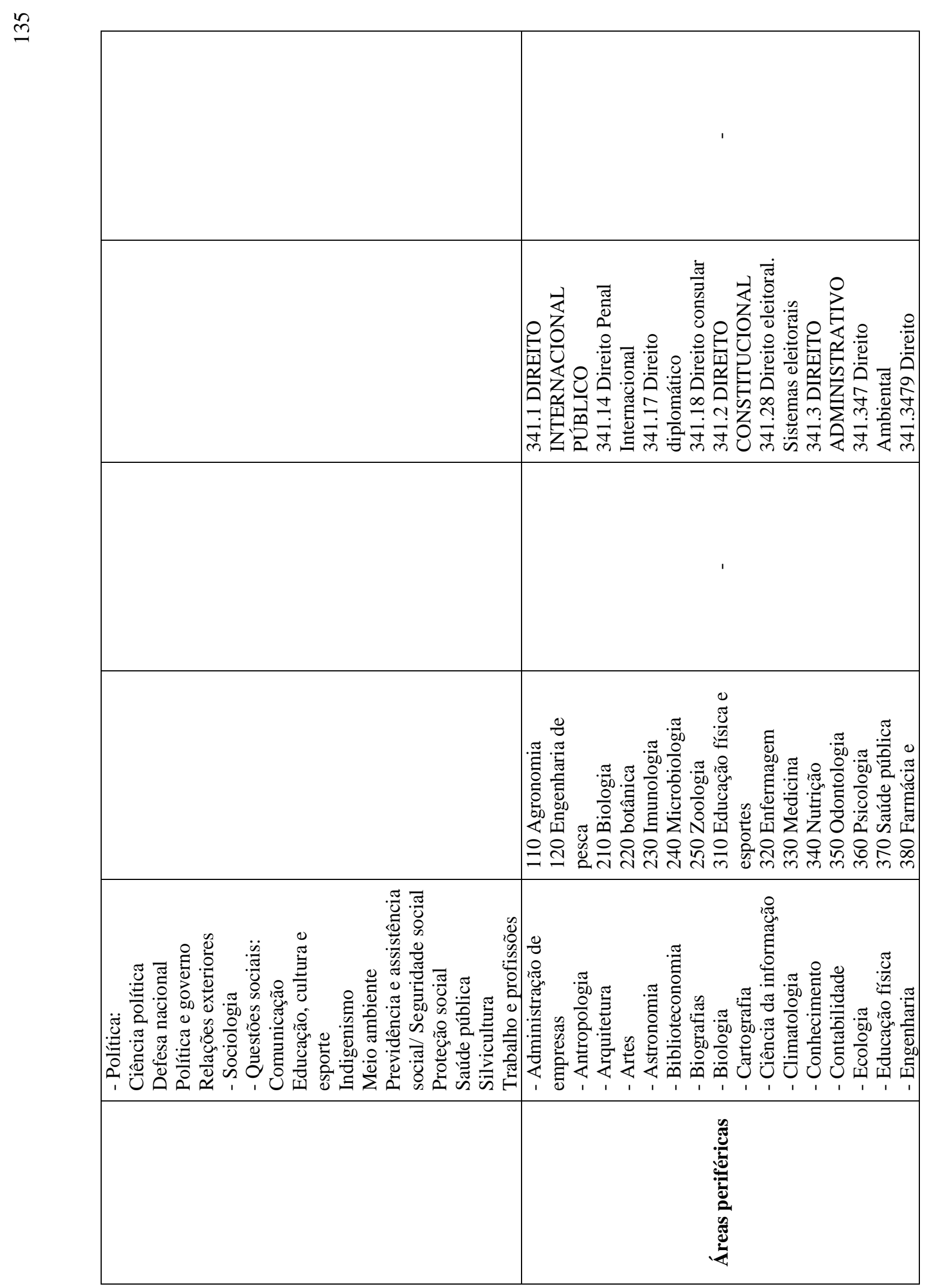




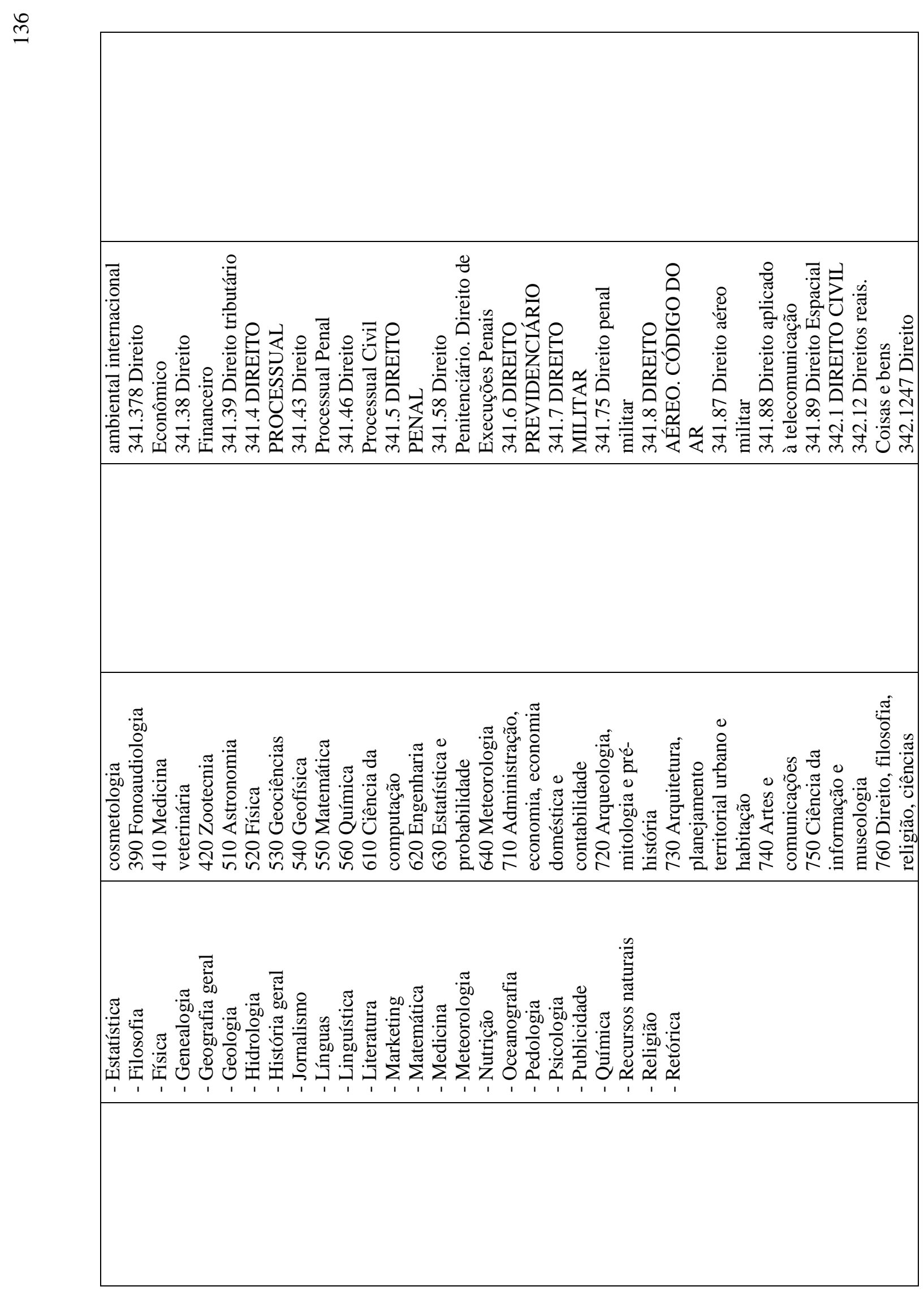


nิ

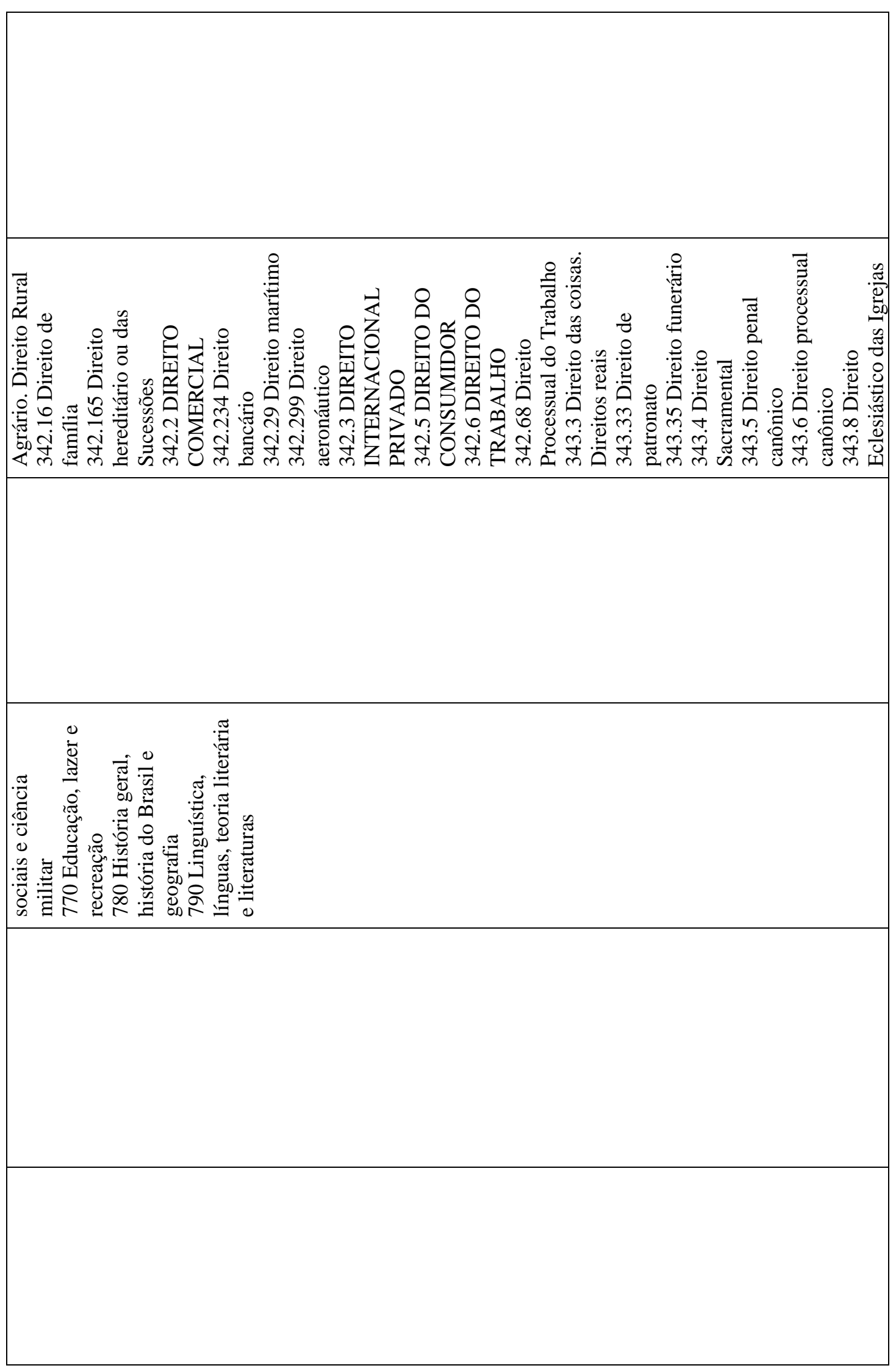




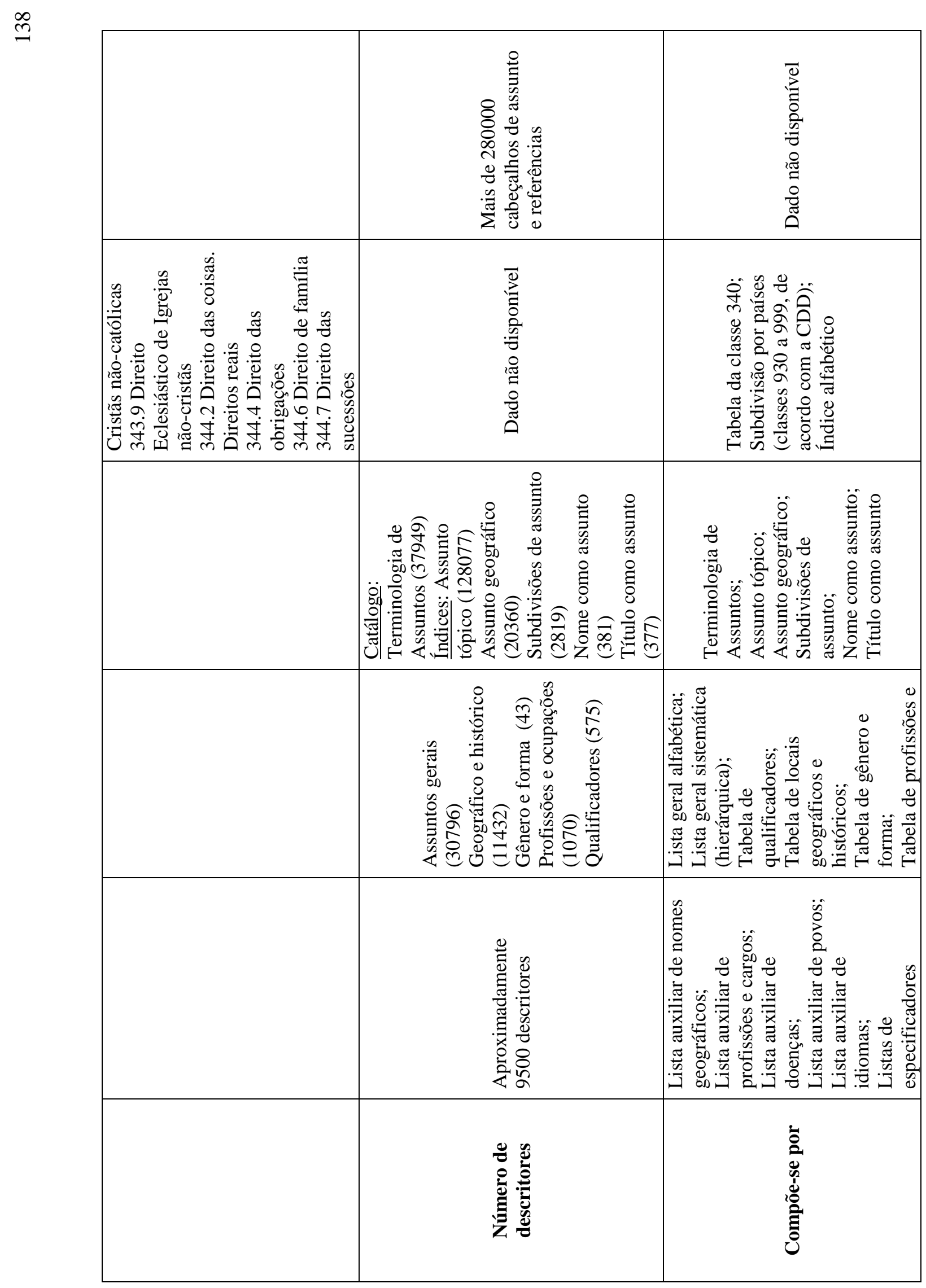


ติ

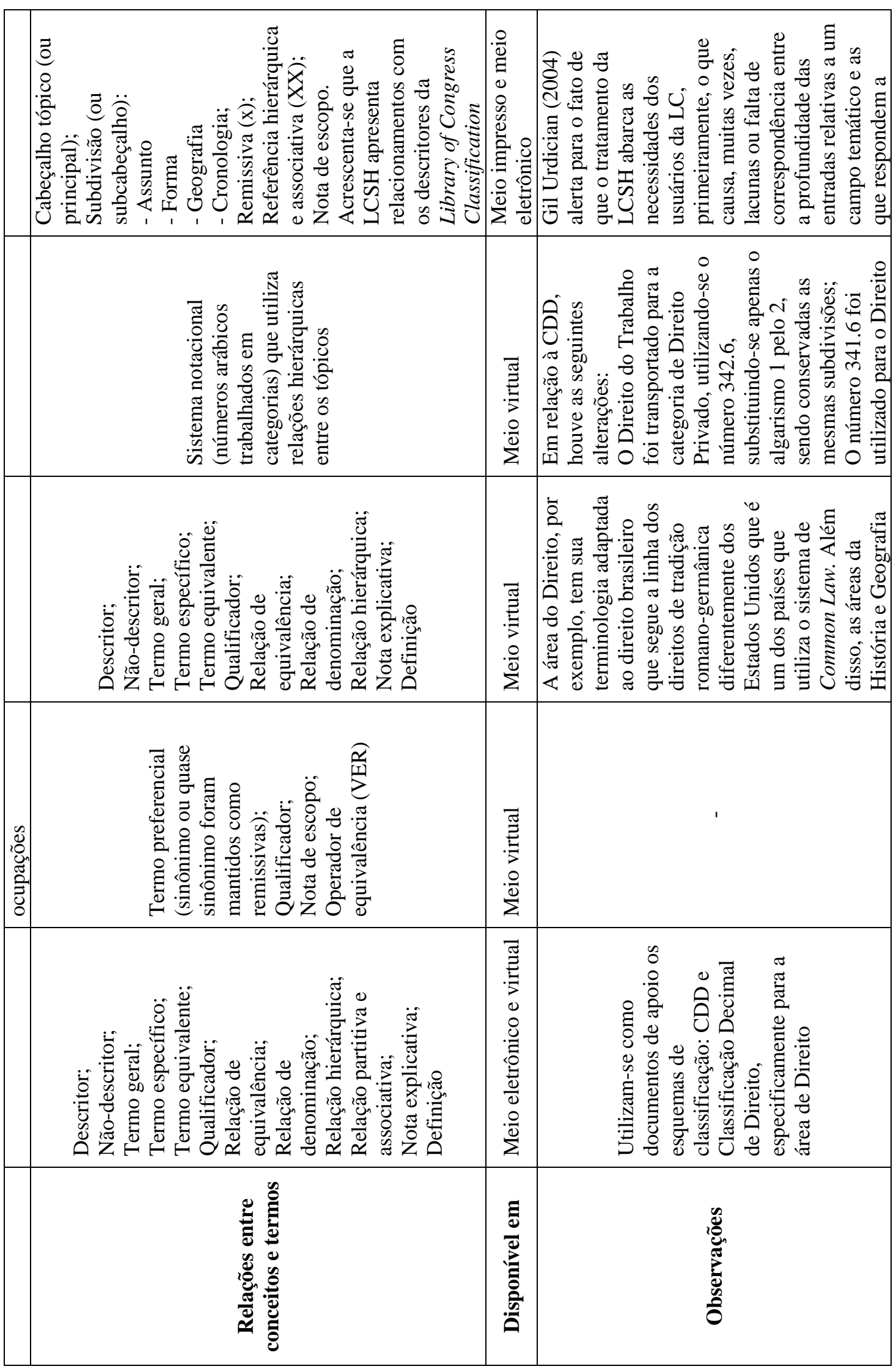


q

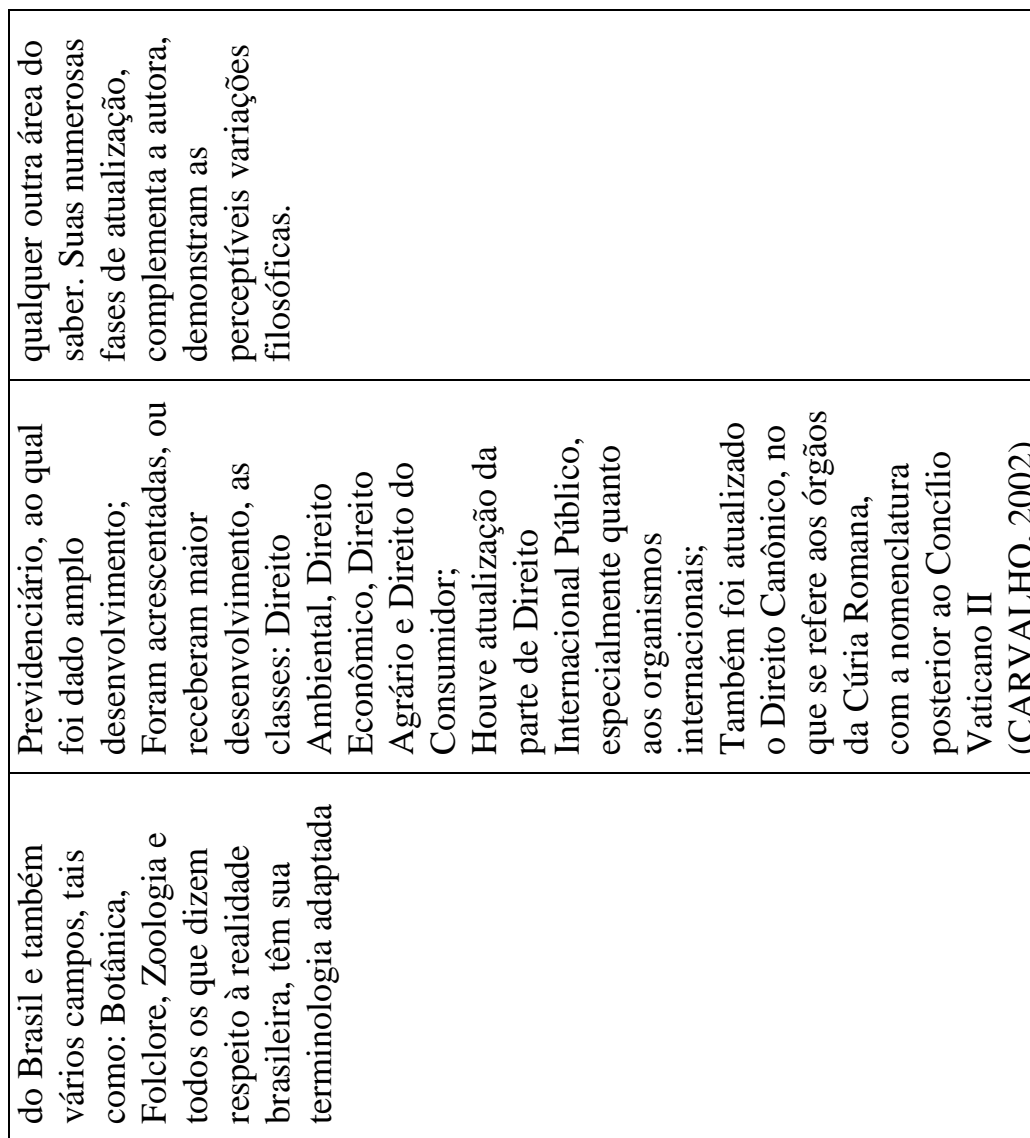

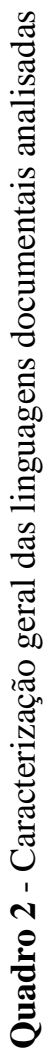

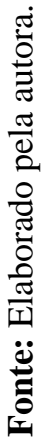

